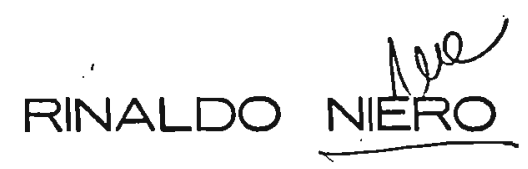

\title{
LABORATÓRIOS DE BACTERIOLOGIA DA TUBERCULOSE
}

subsídios para a implantaçằo de uma rede no Estado de São Paulo 
AOS DOUTORES

MILTON FONTES MAGARAO E LUIS HERRERA MALMSTEN

\begin{abstract}
pelo trabalho que dedicaram aos programas latinoamericanos de luta contra a tuberculose, particular mente äs Redes de Laboratörios de Bacteriologia.
\end{abstract}




\section{A MEU PAI,}

pelas dificuldades que enfrentou venceu na vida

\section{MINHA ESPOSA,}

pelas horas de convivéncli que perdemos

\section{A MEUS FilHOS gLAUCO}

BRENO

como estrmulo. 


\section{AGRADECEMOS}

-Ao Prof. Dr. ROBERTO BROLIO, pela orlentação, apolo e dedicação que nos deu na reallzação deste trabaIho;

-Ao Prof: Dr. OIOGENES AUgUSTO CERTAIN, responsavel por nosso ingresso na carreira docente e pelas pri meiras orlentaçöes a este trabalho;

-Ao Dr. DAHIEL BIASSOTO MANo, da Divisão Nacional de Tuberculose, pelos contiecimentos práticos que nos transmltiu;

-AOS DrS. ANNIBAL GIL DE OLIVEIRA e EMILIA SEABRA SAN TIAGo, pelos dados obtidos junto à Coordenadoria dé Saúde da Comunldade;

-Ao Dr. GILBERTO RIBEIRO ARANTES, pela Importante co laboração que nos prestou Junto à Dlvisão Regionat de Saúde de Ribeirāo Preto;

-A Profa. Dra. RUTH SANDOVAL MARCONDES, pelas vallosas observaçōes e revisão deste trabaiho;

-A Profa, SABINA LEA DAVIDSON GOTLIEB, pelo auxilito na elaboração das tabelas estatisticas;

-As senhoras MARIA JOSE DE ANDRADE BELO e LUIZA DA CONCEIÇAO SILVA, pelo apolo e estimulo durante todos estes anos de convivêncla;

- A senhora LEDA CORREA PORTO DE CAMPOS CAMARGO, pela orlentaça na revisảo blbliográfica;

-A COORDENAÇAO DO APERFEIÇOAMENTO DE PESSOAL DE NTVEL SUPERIOR (CAPES), pela bolsa de estudos que nos fol concedida;

- A todos que, direta ou indiretamente, contribuiram para a realização do presente trabalho. 


\section{I $N$ H $D$ I}

Pàg.

1. INTRODUÇAO $\ldots \ldots \ldots \ldots \ldots \ldots \ldots \ldots \ldots \ldots$ I

2. BACTERIOLOGIA - MEDIDA DIAGNOSTICA PRIORITARIA NUM PROGRAMA DE LUTA CONTRA A TUBERCULOSE

2.1. Considerações Gerais $\ldots \ldots \ldots \ldots \ldots \ldots$

2.2. Consideraçōes Epidemiolōgicas ....... 6

2.3. Considerações Econōmicas ........... 9

2.4. Considerações Sociais ............. 10

2.5. Consideraçōes tēcnicas ............ 11

3. REDE DE LABORATORIOS DE BACTERIOLOGIA DA TUBERCULOSE NO BRASIL ................ 13

3.1. Evolução Histōrica ............... 13

3.2. Estrutura .................. 19

3.3. Atividades $\ldots \ldots \ldots \ldots \ldots \ldots \ldots . \ldots \ldots$

4. SECRETARIA DA SAIDEE DO ESTADO DE SAOO PAULO.. 25

5. LABORATORIOS PERTENCENTES A SECRETARIA DA SA



5.1 . Consideraçōes $\quad \ldots \ldots \ldots \ldots \ldots \ldots \ldots \ldots \ldots . \ldots . \ldots$

5.2 . Distribuição $\ldots \ldots \ldots \ldots \ldots \ldots \ldots \ldots . \ldots . \ldots . \ldots$ 
Pāg.

6. IMPLANTAÇAOO DA REDE DE LABORATORIOS DE BACTERIOLOGIA DA TUBERCULOSE NO ESTADO DE SAOO PAULO

6.1. Considerações Gerais ........... 36

6.2. Etapas da Implantação ........... 37

6.3. Estrutura da Rede de Laboratórios ... 40

6.4. Funçōes de Cada Laboratōrio ........ 42

6.5. Estudo Preliminar para a Implantaçāo de uma Rede de Laboratórios de Bacteriologia da Tuberculose na Divisão Regional de Saúde de Ribeirão Preto-DRS-6

6.5.1. Estrutura Administrativa daDRS -6 e Respectivos Municípios ......

6.5.2. População onde devem ser procurados os Casos de Tuberculose..

6.5 .3 . Custo $\quad \therefore \ldots \ldots \ldots \ldots \ldots \ldots \ldots \ldots \ldots$

6.5.4. Treinamento de Pessoal ..... 105

6.5 .5 . Supervisão $\ldots \ldots \ldots \ldots \ldots \ldots$

6.5 .6 . Avaliação $\ldots \ldots \ldots \ldots \ldots \ldots \ldots . \ldots 122$

7. COMENTARIOS $\ldots \ldots \ldots \ldots \ldots \ldots \ldots \ldots \ldots \ldots . \ldots \ldots$

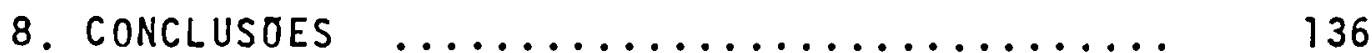

9. RESUMO $\ldots \ldots \ldots \ldots \ldots \ldots \ldots \ldots \ldots \ldots \ldots \ldots \ldots \ldots$



11. REFERENCIAS BIBLIOGRAFICAS ............ 139

12. ANEXOS 


\section{INTRODUÇAO}

A tuberculose ē uma doença de evolução e ritmo seculares. Constitui um dos problemas de Saūde pūbl i ca mais importantes nos paises em desenvolvimento e mesmo em muitos paises tecnicamente desenvolvidos 6,46 . No Brasil, segundo parecer da Comissão Técnica da Divisão Nacional de Tuberculose 10 , é ainda um grave problema de saúde pública.

Estudos realizados por Paz de Almeida ${ }^{2}$ en treze Capitais brasileiras sobre o indice de prevalência da infeç̧ão tuberculosa em escolares com idade média de 7 anos demonstram que o Estado de São Paulo possui um indice rela tivamente baixo, quando comparado aos indices dos demais Estados. Assim, foram encontrados indices de prevalência da infecção, considerando apenas os reatores fortes de $6,6 \%$ em São Paulo - SP, 6,4\% em Curitiba - PR, 19,6\% em Manaus - AM e $25,9 \%$ em Belēm - PA, com uma mēdia geral de $12,2 \%$ nas treze Capitais. No entanto, CERTAIN ecol. 15 encontraram em cerca de $160 . \mathrm{mil}$ crianças examinadas no pe ríodo de 1971 a 1974, indices de prevaléncia da infecção de $6,6 \%, 7,6 \%, 7,3 \%, 7,2 \%$ de reatores fortes, respectivamente para os anos de $1971,72,73,74$, mostrando que a propagação da doença estā se mantendo em ritmo ascenden te. 
Dados obtidos no Departamento Técnico Normativo, da Divisāo de Epidemiologia da Secretaria da Saūde do Esta do de são Paulo7, 8, assinalam que o Estado tem ainda a tuberculose como uma das enfermidades que maior número de casos notificados apresenta em quase todas as Divisões Regionais de Saūde.

A população do Estado encontra-se em grande parte aglomerada em grandes centros urbanos, ou dispersa em pequenas comunidades e regiōes rurais. Estas ültimas con tam praticamente com pouca ou nenhuma assistência sanitária $a^{37}$, o que vale dizer que o mesmo acontece no setor da tuberculose 43 , facilitando a propagação da doença e dificultando o seu controle. Estas observaçōes mostram que os programas de controle da tuberculose não atingem, em profundidade, as āreas rurais e as regiōes desfavorecidas pelo desenvolvimento.

Quanto à descoberta de casos, nota-se a tendēncia em dirigir os recursos diagnōsticos a uma população a parentemente sadia, resultando em baixo rendimento e um al to custo operacional.

o tratamento muitas vezes é iniciado com base apenas nos achados radiológicos, permitindo que uma determi nada proporção de pacientes seja incorretamente rotulada como tuberculose. HITZE 28 , salienta que estes pacientes "etiquetados" de tuberculose são tratados desnecessariamen te, consumindo recursos importantissimos que deveriam ser primariamente concentrados no tratamento dos casos realmen 
te necessitados.

A alta incidência da infecção tuberculosa em nos so meio evidencia que o sistema atual de luta antituberculose não tem podido interromper de maneira evidente a cadeia de transmissão da doença.

os recursos diagnōsticos não são colocados conve nientemente à disposição de toda a população do Estado e, portanto, não se adaptam às suas reais necessidades.

O Comitê de Peritos em Tuberculose da Organização Mundial da Saúde (OMS) no seu 90 Informe 46 salientou que os programas antituberculose nacionais poderão ser exe cutados em qualquer situação, sempre que seu planejanento e aplicação se baseiem em conhecimentos objetivos das condiçōes epidemiológicas, técnicas, econōmicas e sociais. Ainda no mesmo Informe o Comitē especifica que os programas deverão abranger todo o país, ser permanentes, adaptar-se às necessidades da população e estar integrados na estrutu ra sanitāria da coletividade.

os mētodos diagnósticos deverāo obviamente.ser estruturados dentro dos programas de luta antituberculose, assentados também em consideraçōes epidemiolögicas, econōmicas, sociais e técnicas. Se tais reflexões não forem adotadas, o processo de descoberta de casos será solucionado apenas parcialmente.

Os esquemas modernos de controle da tuberculose preconizam a integração progressiva do programa nos servi 
ços gerais de saúde e consideram a bacteriologia uma ferramenta fundamental para a descoberta de casos, o diagnóstico etiológico, o controle da eficācia do tratamento e pa ra a orientação de certos aspectos terapêticos e epidemio $10 \bar{g} i \cos ^{61}$.

No monento atual, a Rede de Laboratórios de Bacteriologia da Tuberculose é uma organização realista que, no Brasil e en muitos países da América Latina, tem se mos trado eficaz, tanto para cumprir objetivos de ordem clinica, como de orden epidemiológica e operacional $20,49,61$.

Este trabalho teve por objetivo estudar as possibilidades da implantação de uma Rede de Laboratōrios de Bacteriologia da Tuberculose no Estado de São Paulo. Foi realizado un estudo preliminar na Divisão Regional de Ribeirão Preto (DRS-6), con o fim de avaliar a viabilidadee exequibilidade, estabelecendo-se algumas diretrizes bāsicas que poder ser adotadas como subsidios para o processo da sua implantação. 
2. BACTERIOLOGIA - MEDIDA DIAGNOSTICA PRIORITARIA NUM PROGRAMA DE LUTA CONTRA A TUBERCULOSE

\subsection{CONSIDERAÇOES GERAIS}

O nūmero estimado de pessoas infectadas pelo bacilo da tuberculose no Brasil, baseado em inquéritos tuber culinicos, atinge quase metade da população ${ }^{10}$. Isto sem dū vida alguma representa um potencial de futuros casos ativos realmente significante. Tal situação epidemiológica propiciou aos métodos de descoberta de casos ocupar um lugar prioritário nos programas de combate à doença.

Esses mētodos sāo indispensāveis para a elaboração dos programas de luta antituberculose e devem ser valo rizados de acordo com as condições epidemiológicas da doen ça na região.

Dos métodos empregados, a radiologia desempenhou, por longo tempo, papel predominante no diagnóstico da enfermidade, cedendo lugar, apōs o advento dos quimioterāpicos, à bacteriologia, cujo papel foi extraordinariamente valorizado33, constituindo hoje a medida prioritāia nos programas de controle da doença, onde a tuberculose ainda constitui problema de Saúde Pūblica. 
Entretanto, não foi apenas em função do uso dos quimioterápicos que a bacteriologia passou a ser elemento de escolna na descoberta de casos. Os países do mundo inteiro, principalmente aqueles em vias de desenvolvimento, passaram a elaborar os programas de combate à doença baseados em dados epidemiológicos, económicos, sociais e técnicos, enaltecendo a bacteriologia como - procedimento fundamental na descoberta de casos de tuberculose $5,18,19,22,28,29,32,38,40,43,45,55$.

\subsection{CONSIDERAÇOES EPIDEMIOLOGICAS}

A cadeia epidemiológica da tuberculose, apresentada na fIGURA n: 1, salienta que, entre os individuos de uma população, alguns contraem a infecção e outros não (A e B). Entre os infectados (B), que HITZE 28 chamou de reservatório da infeção, alguns contrairão a enfermidade e farão parte do grupo dos casos ativos (C), os quais, por sua vez, propiciarão novas infecções e a manutenção do reservatório da infeç̧ão. Os casos ativos poderão falecer (D) ou curar-se (E). Os curados poderão sofrer uma recaida e voltar ao grupo dos casos ativos ou falecer.

Tornou-se necessāria a explicação dos elementos bãsicos da cadeia epidemiológica da tuberculose para que se entenda a importância dos casos ativos, ou seja, dos ca sos epidemiologicamente mais importantes que transmitem a infecção, que são os oasos baciliferos. 
FIGURA I - CADEIA EPIDEMIOLOGICA DA TUBERCULOSE.

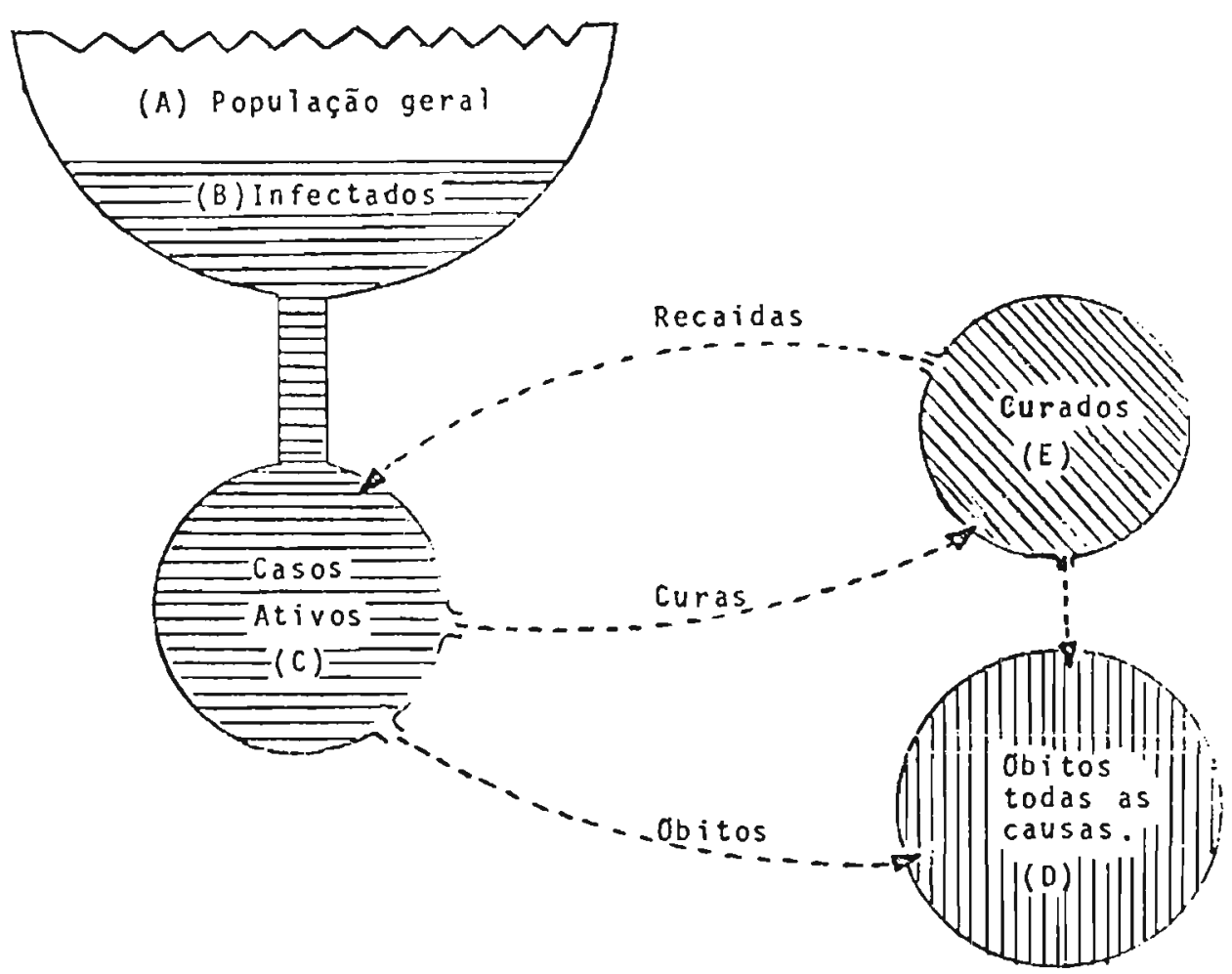

FONTE: Edwards, P.Q. (19).

0 Comitê de Peritos em Tuberculose da OMS, no seu 80 Informe ${ }^{45}$, definiu, do ponto de vista epidemiológico, caso de tubercuzose como sendo toda a pessoa que padece da enfermidade, cujo escarro é positivo ao exame bacteriológico (direto e cultura). Indivĩduos apenas com ima gens radiológicas anormais seriam considerados como suspe tos, requerendo uma vigiläncia baseada no exame bacterio1ógico.

Inümeros trabalhos cientificos surgiram avalian do a importāncia do "caso" e do "suspeito". 
RAJ NARAIN 88 , comparando a infecciosidade dos casos, mostrou que a proporção de crianças infectadas nas idades entre 0-14 anos, residindo com casos, com suspeitos e com não casos, foi de $41 \%, 20 \%$ e $12 \%$, respectivamente.

GRZYBOWSKI e ALLEN 89 estudaram a prevalēncia de tuberculose ativa entre 1.116 contactos que conviviam com pessoas portadoras de tuberculose pulmonar. A prevalencia foi de $6,5 \%$ quando o escarro do caso "index" foi positivo pela microscopia direta; $1,3 \%$ quando o bacilo do caso "index" foi encontrado somente pela cultura e 1,1\% quan do a cultura foi negativa.

GRZYBOWSKI, BARNETT \& STYBLO ${ }^{24}$ verificaram que as crianças que tiveram contactos intimos com pacientes com escarro positivo pelo exame direto foram tuberculina positivos em $35 \%$ nas idades de 0 a 4 anos; $43 \%$ nas idades de 5 a 9 anos e $52 \%$ nas idades de 10 a 14 anos.

MEIJER e col.61 concluiram que os pacientes con siderados como fontes de infecção mais importantes "são aqueles em cujo escarro o bacilo da tuberculose pode ser de monstrado pelo exame direto".

Baseados nestas pesquisas, podemos notar a diferença de significaçāo epidemiológica do caso e do suspeito. Fazendo-se esta distinção evitar-se-ia, no momento epide miolōgico atual, o excesso de diagnōstico, "recarregando a capacidade limitada de um programa (ou centro sanitārio) 
com pacientes que, de acordo com a definição, não constituem o objetivo do programa" 28.

Pode-se concluir, portanto, que ao procurarmos diminuir o número de casos da população, ou seja, os casos com exame bacteriológico positivo, certamente estaremos di minuindo novas infecções.

\subsection{CONSIDERAÇOES ECONOMICAS}

Nos paises em vias de desenvolvimento as verbas destinadas à saúde são relativamente pequenas e reduzem-se ainda mais quando destinadas aos programas de tuberculose.

Desta maneira, os métodos diagnósticos para a descoberta de casos deverão ser avaliados não somente pelo custo de cada exame, mas pelo custo aproximado de cada ca so descoberto.

Não hã dūvida alguma que, analisando custo por caso, o exame direto do escarro representa prioridade econōmica. Alēm disso, apōs a confirmaçāo diagnōstica, o pa ciente poderā ser imediatamente tratado.

MEYER e COUDREAU 39 salientaram que os dois impe rativos que tornam a bacteriologia medida prioritāria nos programas de luta contra a tuberculose nos paises em desen volvimento são: "lo) a necessidade de permanecer nos limi tes das possibilidades financeiras; 20) a necessidade de agir com o máximo da eficācia". 
Hă divergências de opiniōes quando a radiologia è analisada no sentido tēcnico-individual ${ }^{36}, 39,62$, mas quando empregada indiscriminadamente, para o reconhecimen to em massa, os pareceres são unānimes ao afirmar que o exame radiolōgico é muito dispendioso em relação a seu rendimento $20,28,31,34,36,54,57$.

De qualquer forma, os paises em desenvolvimento não podem colocar ao alcance de toda a população um aparelhamento de alto custo e manutenção dificultosa, que exige para seu funcionamento técnicos especializados.

\subsection{CONSIDERAÇOES SOCIAIS}

0 Comitē de Peritos em Tuberculose da OMS, no seu 79 Informe 44 conclui que a maioria dos doentes com tu berculose pulmonar contagiosa conhece sua doença e procura expontaneamente o médico.

Muitas pesquisas foram efetuadas em virtude de numerosos paises estarem empregando a radiologia em massa e de trabalhos realizados, SWALLON E SBARDARO59, MARCHAL e col..$^{34}$, GOTHI e col. ${ }^{21}$, HITZE 28 , EDWARds ${ }^{19}$ e MEIJER, BARNETT, KUBIK $E$ STIBLO ${ }^{36}$, concluiram que a maior parte dos casos novos não se descobre por campanhas de detecção em massa, senão porque os enfermos com sintomas pulmonares (sintomāticos - respiratōrios) buscam por sua prōpria iniciativa os serviços de saúde. 
MEIJER e col.36, em trabalho realizado no canadā, Checoslováquia e Países Baixos, concluiram que 50 a $66 \%$ dos casos com baciloscopia notificados se apresentaram expontaneamente aos serviços de saūde sem terem sido descobertos ou convocados por eles.

LABARQU ${ }^{30}$, na Algeria, salientou que "o valor dos sintomas para a descoberta da tuberculose pulmonar impōe num paīs em vias de desenvolvimento um esforço para se organizar uma rede de descoberta sintomática eficaz, a fim de reconhecer o māximo de tuberculosos excretores de bac los" e finaliza, comentando: "diz-se da importāncia em concordar na descoberta bacteriolögica, na qual a extensão permite, de um lado, a descentralização do diagnōstico até as zonas rurais afastadas e, de outro lado, a integração da luta antituberculose na atividade normal das unidades de saúde pública. Todo outro meio de descoberta seria.irrealista, inaplicāvel à escala de todo um paīs e, sobretudo, ineficaz.".

Devemos, pois, dirigir os mētodos diagnósticos de descobertas de casos a todo paciente com sintomatologia respiratória de maneira permanente e que atendam suficien temente às necessidades da população.

\subsection{CONSIDERAÇOES TECNICAS}

O advento da quimioterapia modificou o enfoque dos métodos de descoberta de casos de tuberculose. Os mé- 
todos tradicionalmente empregados e que visam radiografar toda uma população e descobrir a tuberculose incipiente, perderam sua importāncia em saūde pūblica, principalmente em virtude do seu baixo rendimento e alto custo operacional nos programas de controle da tuberculose $28,34,36$.

Não hã dūvida que, nos paĩses em vias de desenvolvimento, as medidas que visam ao diagnōstico deverāo estar firmadas em técnicas simples, cujo rendimento e operacionalidade sejam adequados aos objetivos básicos do pro grama 28,39 .

A bacteriologia pode contribuir bastante no diag nōstico e avaliação do tratamento ${ }^{22}$ porque, alēm de forne cer o diagnóstico etiológico da doença, indica o esquema antibiōtico a ser empregado e, finalmente, controla a ef cácia do tratamento 25 .

Dos métodos bacteriolōgicos, o exame direto do escarro pode ser executado por qualquer pessoa que possua um minnimo de escolaridade e tenha recebido um treinamento adequado, de no māximo 3 semanas ${ }^{55}$. E um mētodo realmente simples, de fācil execução, barato, cuja maior exigência em termos financeiros ē o microscōpio.

Por força, portanto, destas quatro considerações (epidemiolōgica, econômica, social e tēcnica) deve-se situ ar a bacteriologia como medida diagnóstica prioritária nos programas de luta contra a tuberculose. 
3. REDE DE LABORATORIOS DE BACTERIOLOGIA DA TUBERCULOSE NO BRASIL

\subsection{EVOLUÇAO HISTORICA}

Foi nos anos de 1947 e 1948 que a OMS começou a preconizar o emprego uniforme das técnicas de controle da tuberculose e a necessidade de confirmação bacteriológica nos diagnōsticos efetuados por radiologia 20 . Em 1950, o Comitê de Peritos em Tuberculose, no seu 50 Informe ${ }^{20}$, salienta que "somente se recorra à exploração radiogrāfica de massa quando se dispuser de meios clínicos e de labora tōrio para vigiar a evolução dos casos". Foi justamente nesse período que se deu maior ênfase à medida de exploração radiogrāfica de massa, que poderia descobrir a tubercu lose' incipiente.

Atē aquela época, no Brasil, os laboratōrios de bacteriologia da tuberculose pertencentes aos serviços de saúde de cada Estado funcionavam isoladamente e apenas rea lizavam diagnōsticos complementares dos casos radiologicamente suspeitos.

0 ano de 1960 foi um ano decisivo para a bacteriologia da tuberculose. No seu 70 Informe, o mesmo Comi- 
tê de Peritos" concluiu que "o indice mais fidedigno da magnitude do problema, que se pode obter com levantamentos sobre a prevalēncia de tuberculose, ē provavelmente a prevalēncia de indivīduos que eliminam bacilos; em segundo lugar a prevalência de imagens significativas nas explora ções radiogrāficas dọ tōrax e tambēm muito importante as reações positivas à tuberculina".

Em 1964, o Comitē da OMS definiu no seu 89 Infor me "caso de tuberculose" e recomenda que todos os casos sejam objeto de tratamento imediato, enquanto que as pessoas com imagens radiológicas anormais somente recebam vi gilāncia baseada no exame bacteriológico ${ }^{45}$.

A partir dessa ēpoca o Ministērio da Saũde e Secretarias da Saūde de todos os Estados do Brasil começam a enaltecer a necessidade da confirmação bacteriolögica nos individuos suspeitos radiologicamente e algumas idéias principiaram a surgir no sentido de se organizar um serviço nacional de laboratórios de bacteriologia da tuberculose que pudesse cobrir integralmente a população nacional.

Em julho de 1966 é reatizada na cidade de Panamá a I Reunião de Diretores de Campanhas Antituberculosas da América Central e Panamã. E dado o primeiro passo no sentido de se conseguir a regionalização e coordenação dos pro gramas das Campanhas Antitubercutose ${ }^{18}$. Nos tópicos que se referem à Epidemiologia e Métodos Diagnósticos, o grupo de trabalho concluia sobre a Bacteriologia da seguinte maneira: 
"1 - Fica ratificada a utilidade que tem a radiologia e a descoberta do doente juntamente com a prova da tuberculina, insistindo-se na necessidade de equiparar o estudo bacteriológi co ao ritmo dos outros métodos em sua utilização de acordo com os recursos disponiveis.

2 - A recomendação deve ser a utilização dos três métodos. O minnimo deve ser a utilização da prova tuberculinica e radiologia; ou de tuberculina com baciloscopia; ou só tuberculi na, determinados pela acessibilidade e dispó nibilidade de recursos".

Mais adiante, no ponto 4 do mesmo Informe, lê-se:

4 - "a bacteriologia serā utilizada nos sintomāticos, assim como tambēm nas pessoas que apresentam imagens suspeitas".

Em 12 de agosto de 1966 a Comissão Técnica da Campanha Nacional Contra a Tuberculose ${ }^{13}$ reuniu-se e esta beleceu as diretrizes gerais para o funcionamento da Rede de Laboratōios de Bacteriologia da Tuberculose, da Campanha Nacional Contra a Tuberculose. Elaborou-se o esquema geral, admitindo-se que "a um laboratório central deve ser atribuĩda a condição de Laboratório de Referência para o Pais, de modo a permitir que se converta efetivamente em örgão central de carāter normativo em relação à Rede de La boratōrios, cumprindo função executiva somente no que diz respeito ao levantamento de dados de rotina mais significa tivos e ao controle de programas de pesquisas nacionais e internacionais". Ho prōprio esquema acentuou-se: "além 
do laboratörio central, participarāo da Rede de Laboratōrios, em número crescente para atender às necessidades do Pais, laboratórios regionais, cujo trabalho deve acompanhar o padrão tēcnico do Laboratōrio de Referência"; mais adiante: "finalmente nesse conjunto, integrando a Rede de Laboratōrios de Bacteriologia da Tuberculose, se inserem as unidades de bacterioscopia, que devem ser tão numerosas quanto os hospitais, dispensārios, ambulatōrios e postos de saūde em toda a parte onde se faça diagnōstico e trata mento da tuberculose". As atribuiçōes destes diferentes tipos de laboratōrios, a padronizaçāo tēcnica, as investigações nacionais e participação em programas internacionais e a coordenação das atividades laboratoriais são os tópicos principais levantados neste trabalho. Nesta mesma oca siāo, dentro do programa de padronização tēcnica, um ajuste de cooperação é firmado entre o Serviço Nacional de Tuberculose do Ministērio da Saūde e a Secretaria da Saūde do Estado da Guanabara (S.S.A.). Tal ajuste prevē como clāusula primeira:

"Ao Laboratōrio Central de Tuberculose, da S.S.A., fica atribuĩda a condição de Laboratório de Refe rência da Campanha Nacional Contra a Tuberculose". $^{\text {. }}$

Estava firmada, portanto, em termos teōricos, a implantação da Rede de Laboratōrios de Bacteriologia da Tu berculose no Brasil.

Em outubro do mesmo ano (1966) reuniu-se em Bue nos Aires, Argentina, o Comitē Regional Latinoamericano 
da União Internacional Contra a Tuberculose para a realiza ção da VII Reunião, cujo tema foi "La Bacteriologia en los Programas de Control de la Tuberculosis. Métodos Técnicos y Administrativos Aplicables en la America Latina32". Da reunião participaram eminentes autoridades em tuberculose como, por exemplo: Dr. Luis Herrera Malmsten (Chile), Or. Milton Fontes Magarão (Brasil), Dr. Victor Chiesa (Argentina), Dr. Juan de Dios Echevers (Panamä), Dr. Josē I gnăa cio Baldó (Venezuela), Dr. K. Bartamann (Alemanha), Dr. John Holm (na ocasiāo, secretārio executivo da Uniōn Inter nacionale Contre la Tuberculose (U.I.C.T.), alēm do Dr. Pedro Iturbe (Venezuela), que coordenou os trabalhos desta reunião. Discutiu-se a validade da bacteriologia como medida imprescindivel num programa de luta contra a tuberculose, devendo-se concentrar as açōes diagnōsticas no gru po de pacientes sintomaticos, preconizando-se como método prioritário o exame direto do escarro que descobriria a grande maioria dos casos mais infectantes. Enfatizou-se a viabilidade do emprego da bacteriologia em toda a América do Sul pelas características epidemiolōgicas, sōcio-econōmicas, politicas e geogräficas semelhantes dos vārios paĩ ses. Com respeito ao número de laboratórios existentes, notou-se uma grande deficiēncia quanto ao grau de cobertura dado à população pelos serviços, salientando-se como principal problema a população rural.

Foi nesta oportunidade que o Dr. Milton Fontes Magarão apresentou um tema sobre "Meios tēcnicos e adminis trativos para melhor utilização de microbiologia nos pro- 
gramas de luta contra a tuberculose $33 "$ onde, pela primeiravez, se mostrou as diretrizes para a organização e desenvolvimento intensivo de um programa diagnōstico para os países sulamericanos e, principalmente, para o Brasil.

Em 18 de maio de 1972 o Ministērio da Saūde e a Organização Panamericana da Saūde/Organização Mundial da Saūde (OPS/OMS) firmaram um acordo no sentido de desenvol ver um programa de bacteriologia da tuberculose, de onde surgiram medidas que hoje em dia são adotadas em todos os paises latinoamericanos.

Em 20 de janeiro de 1973, atravēs da Portaria no 2, de 20 de janeiro de 1973, publicada no Diārio oficial da União em 06 de fevereiro de $1973^{12}$, foi oficializada a criação da Rede Nacional de Laboratórios de Bacteriologia da Tuberculose, bem como da Coordenação da Rede ivacional de Laboratōios de Bacteriologia da Tuberculose, de acordo com os seguintes itens:

"1 - As atividades de bacteriologia de tuberculose ficam organizadas sob forma de sistema, cuja atuação integrada serā objeto de instru mento de previsão, orientação e coordenação, a "Rede Nacional de Laboratórios de Bacterio logia de Tuberculose".

"2 - Integrarão a Rede, respeitada a subordinação aos órgãos que pertençam, os laboratórios que realizam ou possam fazer bacteriologia de tu berculose, sejam de carāter oficial, autārqui co ou pertencentes a instituiçōes particulares". 
"3 - Para possibilitar a coordenação das unidades integrantes do sistema, fica criada junto à Campanha Nacional Contra a Tuberculose a Co ordenação da Rede Nacional de Laboratōrios de Bacteriologia de Tuberculose".

A partir dessa época, o progresso da Rede Nacional tem caminhado lentamente e somente nos Estados do Rio Grande do Sul, Santa Catarina, Paranā, Rio de Janeiro, Espirito Santo, Sergipe, Alagoas, Cearā, Maranhão, Piaū, Rio Grande do Norte, Pernambuco e Bahia ela conseguiu realmente efetivar-se graças aos incansāveis esforços de al guns técnicos que vêem na implantação da Rede, a diminuição efetiva do nūmero de casos realmente contagiantes, que asseguram permanentemente a manutenção do reservatōio da infecção.

\subsection{ESTRUTURA}

A estrutura atual da Rede de Laboratōrios de Bac teriologia de Tuberculose no Brasil pouco difere daquela apresentada pelo Dr. Milton Fontes Magarão na Argentina, no ano de 1966. Com a criação definitiva da Rede Nacional e respectiva Coordenação, ficou assim estruturada a Rede de Bacteriologia de Tuberculose, integrada aos.. Laboratórios de serviços de saūde, constitūida pelos seguintes nīveis :

- Coordenação da Rede;

- Laboratṓrio de Referência; 
- Laboratórios Centrais de cada Estado, integrando - Laboratório Central de Saúde;

- Serviços Regionais, integrando o Laboratório Regional de Saúde;

- Serviços Locais, integrados no Laboratōrio Geral;

- Postos de Colneita de Amostras (PCA) em serviços de saúde sem laboratórios.

\subsection{ATIVIDADES}

Das funções atribuídas a cada serviço cabe à:

\subsubsection{Coordenação da Rede}

a) articular-se com os órgãos e entidades pứblicas e privadas, com o fim de estimular a integração dos seus laboratōrios na Rede $\mathrm{Na}$ cional;

b) padronizar métodos e técnicas de trabalho de rotina e especializados em bacteriologia da tuberculose, a fim de uniformizar e permitir a execução dessas atividades de modo simplificado e adaptado a qualquer região do Pais;

c) promover a coleta uniforme e sistemática de dados bacteriológicos, de modo a permitir o conhecimento da situação epidemiológica da tuberculose no Paĩs; fornecer subsidios e fixar diretrizes adequadas aos programas na 
cionais de luta contra a tuberculose em con sonāncia com a politica nacional de saúde;

d) promover o aperfeiçoamento de pessoal para a execução de tarefas especificas no campo da bacteriologia da tuberculose;

e) promover a padronização do material e do equipamento indispensáve 1 ao funcionamentodos laboratórios de bacteriologia de tuberculose do País;

f) avaliar periodicamente a concepção dos programas da Rede e sua adequação aos objetivos en vista;

g) progranar investigações de tipo têcnico, epidemiológico e operacional;

h) manter a coordenação com a chefia da Rede em cada Estado;

i) fazer a supervisão direta e indireta e a avaliação das redes estaduais;

j) assessorar na aquisição e distribuição dos reativos, dos potes de colheita de escarro e outros materiais.

\subsubsection{Laboratörio de Referência}

a) ser o Laboratório de Referência da especialidade para todo o Pais;

b) ser o centro de estudos das resistências pri márias e secundārias do ponto de vista epi- 
demiológico;

c) efetuar os estudos de sensibilidade de ordem clinica e de tipificação das micobactê rias, solicitados pelos laboratórios do Pá is;

d) adestrar pessoal novo e readestrar o antigo nas técnicas de cultivo, provas de sensibilidade e tipificação;

e) atuar como serviço central da área em que estā localizado, e tambēm de outras āreas que não contem com serviços específicos.

\subsubsection{Laboratōrio Central do Estado}

a) efetuar baciloscopias e cultivo para a área a que serve;

b) efetuar o adestramento do pessoal novo e 0 readestramento do antigo, nas técnicas de colheita de amostra de escarro e de bacilos copia;

c) manter a coordenação dos serviços do Estado para a remessa das amostras de escarro;

d) fazer a supervisão direta e indiretados ser viços da Rede;

e) os laboratōrios que jā realizam teste de sen sibilidade e os que venham a ter condições para fazē-lo devem cumprir essa ação;

f) recorror ao Laboratōrio de Referēncia para 
as tēcnicas mais especializadas;

g) levantar a estatistica quantitativa e quali tativa dos exames realizados no Estado;

h) distribuir os reativos, potes de colneitas de escarro e outros materiais aos serviços locais.

3.3.4. Laboratórios Regionais e Locais

a) efetuar unicamente o exame microscōpico direto das amostras de escarro da sua prōpria ārea, como das que receba dos postos de colheita das áreas vizinhas;

b) encaminhar ao Laboratório Central do Estado as amostras para exames mais especializados;

c) recolher a informação minnima estabelecida e remetê-la, periodicamente, ao Laboratōrio Central do Estado.

3.3.5. Postos de Colheita de Amostras

a) colher amostra de escarro no pote adequado, enviā-la ao laboratório local ou regional cor respondente.

3.3.6. Laboratōrios Especiais de Bacteriologia da Tuberculose

situados em sanatórios, hospitais para paci 
entes broncopulmonares e em cátedras de tisiologia e pneumologia, tais serviços escapam a essas normas gerais; deverão, porëm, integrar-se na Rede Estadual, visando co operar com o Laboratório Central do Estado. 


\section{SECRETARIA DA SAUDE DO ESTADO DE SÃO PAULO}

A Reforma Administrativa da Secretaria da Saūde do Estado foi iniciada no ano de 1967, graças a um grupo de trabalho composto por sanitaristas da Secretaria da Saú de e da Faculdade de Saūde Pūblica, que fixou as diretrizes bāsicas para o estudo da Reforma ${ }^{53}$. Com a colaboração do Grupo Executivo da Reforma Administrativa, uma sērie de estudos parciais foi sendo concluida e a partir daí diversos Decretos foram promulgados atendendo aos aspectos prio ritārios e em conformidade com o próprio plano.

Quatro āreas de ação conjugadas foram esboçadas, obedecendo a princīpios de organização administrativa: $\bar{a}-$ rea deliberativa, ārea executiva, ārea assistencial assessora e ārea assistencial auailiar ${ }^{53}$. Este esquema bā sico foi complementado por diretrizes que orientaramos tra balhos de: integracāo dos servicos em nivel local, erigin do-se o Centro de Saúde como unidade sanitāria polivalente; descentralização executiva atravēs da criação de ōr gãos regionais (Divisões Regionais de Saūde e Distritos Sa nitārios); centralização normativa, visando ao pronto atendimento na prestação de serviços, ao lado da atuação normativa centralizada e especializada; sistema, visando ao efetivo entrosamento de todos os órgãos, funcionando o 
organismo como um todo indivisivel; supervisão permanente e continua; criacāo de carreiras especificas do campo da saūde pública, formaşão e adestramento de pesooal que cons titui a necessidade bāsica da reforma; e saneamento ambiental onde se incluem atividades de significação fundamental para a execução dos programas de Saúde pública.

Quatro Coordenadorias foram criadas: Saūde da Comunidade, Assistēncia Hospitalar, Saūde Mental e Ser viços Técnicos Especializados ${ }^{53}$. Com exceção da Assistência Hospitalar, as atividades de Saúde prestadas à comunidade constituem atribuição da Coordenadoria de Saúde da Comunidade, que alberga 11 Divisōes Regionais, 1 Divi são Especial e 69 Distritos Sanitārios, distribuídos por todo o Estado.

A nível local, as atividades de Saūde Pública pre conizam os seguintes programas:

\section{1 - Programa Minimo}

a) imunizaçōes e, eventualmente, quimioprofila$x i a$;

b) saneamento do meio;

c) visitação sanitāria;

d) educação em saūde pūblica;

e) assistência mēdico-sanitāria intermitente. 


\section{2 - Programa Resumido}

a) controle de doenças transmissiveis;

b) saneamento do meio;

c) higiene materna e da criança;

d) assistēncia mêdico-sanitāria não especializada ;

e) controle da tuberculose e da hanseníase, a car go de clinico geral;

f) epidemiologia e estatística;

g) enfermagem;

h) educação em saúde püblica;

i) administração.

\section{3 - Programa Desenvolvimento com Algumas Exceções}

a) controle de doenças transmissiveis;

b) saneamento do meio;

C) higiene materna e da criança;

d) assistēncia mēdico-sanitāria;

e) controle da tuberculose e da hanseniase, nāo obrigatoriamente por especialistas;

f) odontologia sanitāria;

g) nutrição;

h) epidemiologia e estatistica;

i) enfermagem;

j) educação em saūde pūblica; 

1) laboratório;
m) administração.

\section{4 - Programa Desenvolvido}

a) controle de doenças transmissĩveis;

b) Saneamento do meio;

c) higiene materna e da criança;

d) assistência mēdico-sanitāria especializada;

e) controle da tuberculose e da hanseníase;

f) odontologia sanitāria;

g) nutrição;

h) epidemiologia e estatistica;

i) enfermagem;

j) educação em saúde pública;

1) laboratōrio;

m) administração.

As atividades deste programa sāo executadas pelos respectivios centros de Saüde (C.S.), classificados nu mericamente, segundo o tipo de programa, de $I$ a $V$ e distribuídos pelas diversas Divisōes Regionais de Saúde (DRS), segundo a TABELA no 1 e salientadas na fIGURA $n$ ? 2 . 
TABELA ne I - POPULAÇĀO, NUMERO E TIPO DE UNIDADES SANITÁ RIAS SEGUNDO AS DIVISOES REGIONAIS DE SAGDE DO ESTADO DE SÃO PAULO - 1975

\begin{tabular}{|c|c|c|c|c|c|c|c|}
\hline \multirow{2}{*}{$\begin{array}{lc}\text { DIVISOESS } & \text { RE- } \\
\text { GIONAIS } & \text { DE } \\
\text { SAGDE } & \end{array}$} & \multirow{2}{*}{ POPULAÇÃO } & \multicolumn{3}{|c|}{ Ne/Tipo Unidade } & \multicolumn{2}{|c|}{ Sanitária } & \multirow{2}{*}{ TOTAL } \\
\hline & & $\operatorname{cs} 1$ & $\operatorname{cs} 2$ & $\operatorname{cs} 3$ & $\operatorname{cs} 4$ & $\operatorname{cs} 5$ & \\
\hline $\begin{array}{l}\text { DRS-1-Grande } \\
\text { São Paulo... }\end{array}$ & 10.488 .429 & 21 & 12 & 15 & 27 & 114 & 189 \\
\hline DRS-2-Litoral & 981.627 & 3 & 2 & 1 & 4 & 4 & 14 \\
\hline $\begin{array}{c}\text { DRS-3-Vale do } \\
\text { Paraiba } . . .\end{array}$ & 883.510 & 3 & 4 & 4 & 6 & 16 & 33 \\
\hline $\begin{array}{c}\text { DRS-4-Soroca- } \\
\text { ba } \ldots \ldots\end{array}$ & 1.164 .412 & 5 & 3 & 8 & 12 & 32 & 60 \\
\hline $\begin{array}{c}\text { DRS-5-Campi - } \\
\text { nas } \ldots \ldots \ldots \ldots\end{array}$ & 2.336 .875 & 8 & 6 & 10 & 25 & 59 & 108 \\
\hline $\begin{array}{c}\text { DRS-6-Ribeirão } \\
\text { Preto }\end{array}$ & 1.459 .676 & 5 & 3 & 9 & 20 & 45 & 82 \\
\hline DRS-7-Bauru . & 515.393 & 3 & - & 5 & 9 & 25 & 42 \\
\hline $\begin{array}{c}\text { DRS-8-Rio Pre } \\
\text { to } \ldots \ldots \ldots \ldots\end{array}$ & 905.631 & 5 & - & 5 & 25 & 51 & 86 \\
\hline $\begin{array}{c}\text { DRS-9-Araçatu } \\
\text { ba } \ldots \ldots \ldots\end{array}$ & 553.398 & 2 & 1 & 4 & 11 & 19 & 37 \\
\hline $\begin{array}{r}\text { DRS-10-Presi- } \\
\text { dente Pruden } \\
\text { te } \ldots \ldots \ldots \ldots\end{array}$ & 661.773 & 2 & 2 & 12 & 12 & 28 & 56 \\
\hline DRS-II-Marflia & 633.271 & 4 & 2 & 5 & 13 & 23 & 47 \\
\hline DEVALE $\ldots \ldots$ & 152.975 & - & 2 & - & 5 & 8 & 15 \\
\hline -T 0 T A L & 20.576 .995 & 61 & 37 & 78 & 169 & 424 & 769 \\
\hline
\end{tabular}

FONTE: Diviaño de Estudos e Programas da Coordenadoria do Saúde da Comunidade, Secretaria da Saúde do Estado de São Paulo. 
FIGURA $\mathrm{n} ? 2$ - NUMERO DE UNIDADES SANITARIAS SEGUNDO AS RESIDES ADMIIIISTRATIVAS DO ESTADO DE SÃO PAULO - 1975 .

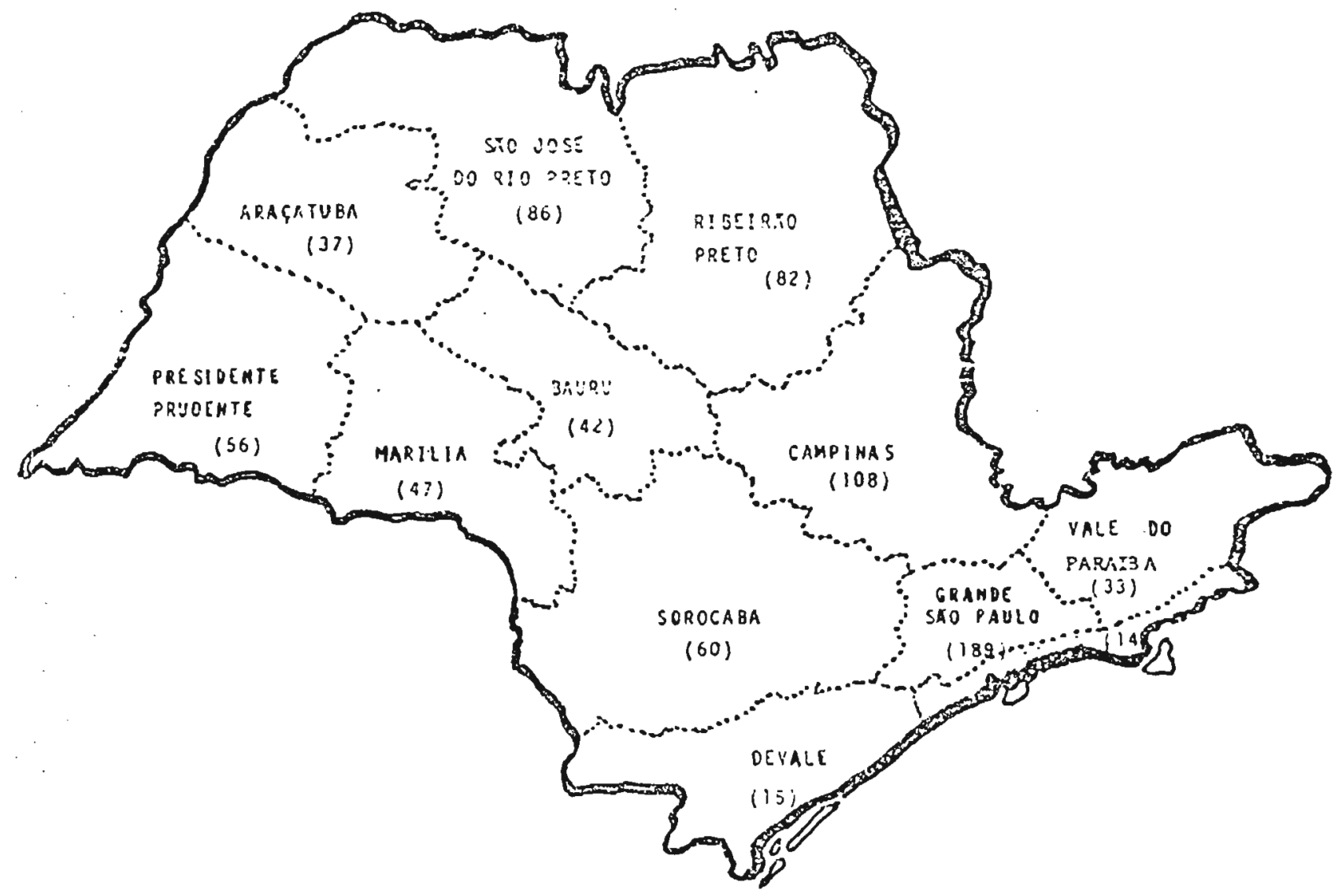

FONTE: Divisão de Estudos e Proaramas da Coordenadoria de Saúde da Comunidade, São Paulo. 
5. LABORATORIOS PERTENCENTES A SECRETARIA DA SADDE DO ESTA DO DE SAO PAULO

\subsection{CONSIDERAÇOES}

Em 1968, atravēs do Decreto $n$ Q 50.192 , artigo $n$ Q 9, item II, letra "d"53, ficou atribuida aos Centros de Saūde, alèm dos serviços norma is de atendimento à população, a execução de Serviços de Laboratōrio nas Unidades Sanitārias.

0 Decreto no 52.182 , de 16 de julho de 196953 , que dispôs sobre a organização da Secretaria de Estado da Saūde, no seu artigo 34 atribuiu à Coordenadoria de Saúde

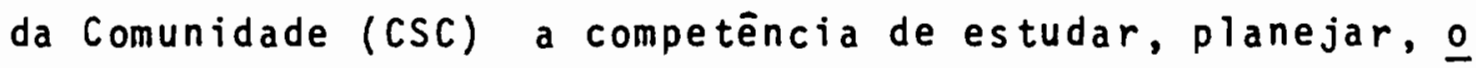
rientar, coordenae, superintender e executar, em conformidade com as normas técnicas emanadas dos órgãos correspon dentes, atividades de exames laboratoriais (item VI). Este mesmo Decreto, no artigo 108 correspondente à Coordenadoria de Serviços Técnicos Especializados, atribuiu a esta Coordenadoria a responsabilidade de estudar, planejar, orientar, coordenar, supervisionar e executar atividades de exames laboratoriais de interesse da Saūde Pūblica (item III). No seu artigo 113 subordinou o Instituto Adolfo 
Lutz à Coordenadoria de Serviços Técnicos Especializados.

Em 28 de abril de 1970 foi elaborado um Decreto que dispōe sobre a organizaçāo do Instituto Adolfo Lutz ${ }^{53}$. No capitulo I, referente à organização, o artigo no 2 re lata que o campo funcional do Instituto Adolfo Lutz compre ende:

I - Supervisionar, coordenar, executar e controlar as atividades dos laboratórios de Saúde Pública do Estado.

II - Realizar:

a) exames de laboratōrio necessārios à elucidação do diagnóstico das molēstias transmissĩveis, parasitārias e neoplāsicas;

b) exames necessários à verificação de portadores de germes, do estado de imunidade e os de mais necessārios ao controle da Saúde Pública;

VI - Prestar assistência tecnolōgica à rede de unida des sanitārias e aos demais ōrgãos da Administra ção Pública que atuam em programas do setor saū de;

VII - organizar cursos de formação tēcnica, aperfeiçoa mento e estágios, para aprimoramento de conhecimentos tēcnico-cientificos no campo de suas atividades.

Ainda no mesmo Decreto, o artigo ne 15 dispōe so 
bre a Divisão de Laboratórios Regionais, que compreende:

I - Diretoria, com Seção de Expediente.

II - 11 (onze) Laboratórios I, com a seguinte estrutu ra padrão:

a) Seção de Patologia Clinica, abrangendo Setor de Microbiologia e Setor de Parasitologia e Anālises Clīnicas;

b) Seção de Bromatologia e Química;

c) Seção de Administração.

III - 7 (sete) Laboratōrios II, com a seguinte estrutu ra padrão:

a) Setor de Microbiologia e Anāilises Clínicas;

b) Setor de Parasitologia;

c) Setor de Administração.

\subsection{DISTRIBUICAO}

- Laboratórios I - Situam-se em Santos, Ribeirão Preto, Campinas, Taubaté, Bauru, São Josē do Rio Preto, Presidente Prudente, Araçatuba e Sorocaba, restando dois a serem instalados na medida das necessidades do Instituto.

- Laboratōrios II - Situam-se em Botucatu, Itapetininga, Ma rîlia, São Carlos, Franca, Santo André e São Caetano do sul.

Nota-se, portanto, que duas Coordenadorias (Serviços Técnicos Especializados e da Comunidade) responsabi- 
lizam-se pelos exames de laboratōrio, atravēs das Unidades Sanitārias existentes, e os Laboratórios do Instituto Adol fo Lutz (Tipo I e II), conforme TABELA n: 2 e FIGURA n: 3 .

Temos, portanto, jā implantados em todo o Estado um potencial de laboratōrios estimados em 64 unidades pertencentes à Secretaria da Saūde, com um potencial minimo de 140 microscōpios, que podem perfeitamente ser adaptados às exigências da Rede Nacional de Laboratōrios de Bacterio logia da Tuberculose, a fim de executar exames baciloscōp cos e culturas, de acordo com suas respectivas capacidades tēcnicas.

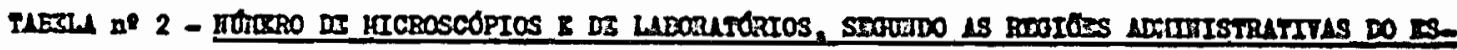
2100 DI S10 PLTLO - 2975

\begin{tabular}{|c|c|c|c|c|c|c|}
\hline \multirow{3}{*}{$\begin{array}{l}\text { RDGiors } \\
\text { IDTHISIRITITLS }\end{array}$} & \multirow{3}{*}{ 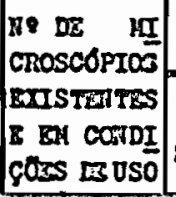 } & \multicolumn{5}{|c|}{ L $\triangle B O B \triangle T O B I O S$} \\
\hline & & \multirow{2}{*}{ 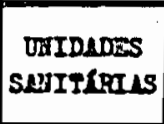 } & \multicolumn{3}{|c|}{ ADOLTO LUTZ } & \multirow{2}{*}{$40: 12$} \\
\hline & & & GXTRAL & Mpo I & Mpo II & \\
\hline DBS-1 - Oreado SẼ Pando ...... & 11 • & $9 \cdot$ & 1 & - & $2 \cdot$ & 22 \\
\hline DBS-2 - LAtoral & 4 & 2 & - & 1 & - & 3 \\
\hline Das-3 - Valo do Parad ba ....... & 4 & 3 & - & 1 & - & 4 \\
\hline DRS-A - Sorocabs ............... & 5 & 2 & - & 1 & 2 & 5 \\
\hline DRS-5 - Caspinas $\ldots \ldots \ldots \ldots$ & 25 & 11 & - & 1 & - & 12 \\
\hline DRS-6 - Rtbolräo Proto ....... & 14 & 4 & - & 1 & 2 & 7 \\
\hline DRS-7 - Bcaro $\quad \ldots \ldots \ldots \ldots \ldots \ldots$ & 16 & 2 & - & 1 & - & 3 \\
\hline DRS-8 - S. José do Bdo Proto .. & 13 & 2 & - & 1 & - & 3 \\
\hline DRS-9 - Lracetrobs $\ldots . . . . . . .$. & 5 & 2 & - & 1 & - & 3 \\
\hline DRS-20- Prosidonto Pradonto ... & 10 & 2 & - & 1 & - & 3 \\
\hline DRS-21- Marll1s $\quad \ldots \ldots \ldots \ldots \ldots$ & 12 & 5 & - & - & 1 & 6 \\
\hline nstus & 3 & 2 & - & - & 1 & 3 \\
\hline- IOTムL & 122 & 46 & 1 & 9 & 8 & 64 \\
\hline
\end{tabular}


Latz, da Secrotarie da Seído do zatado de São Panlo.

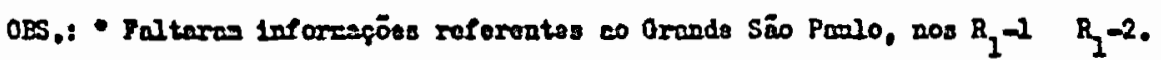



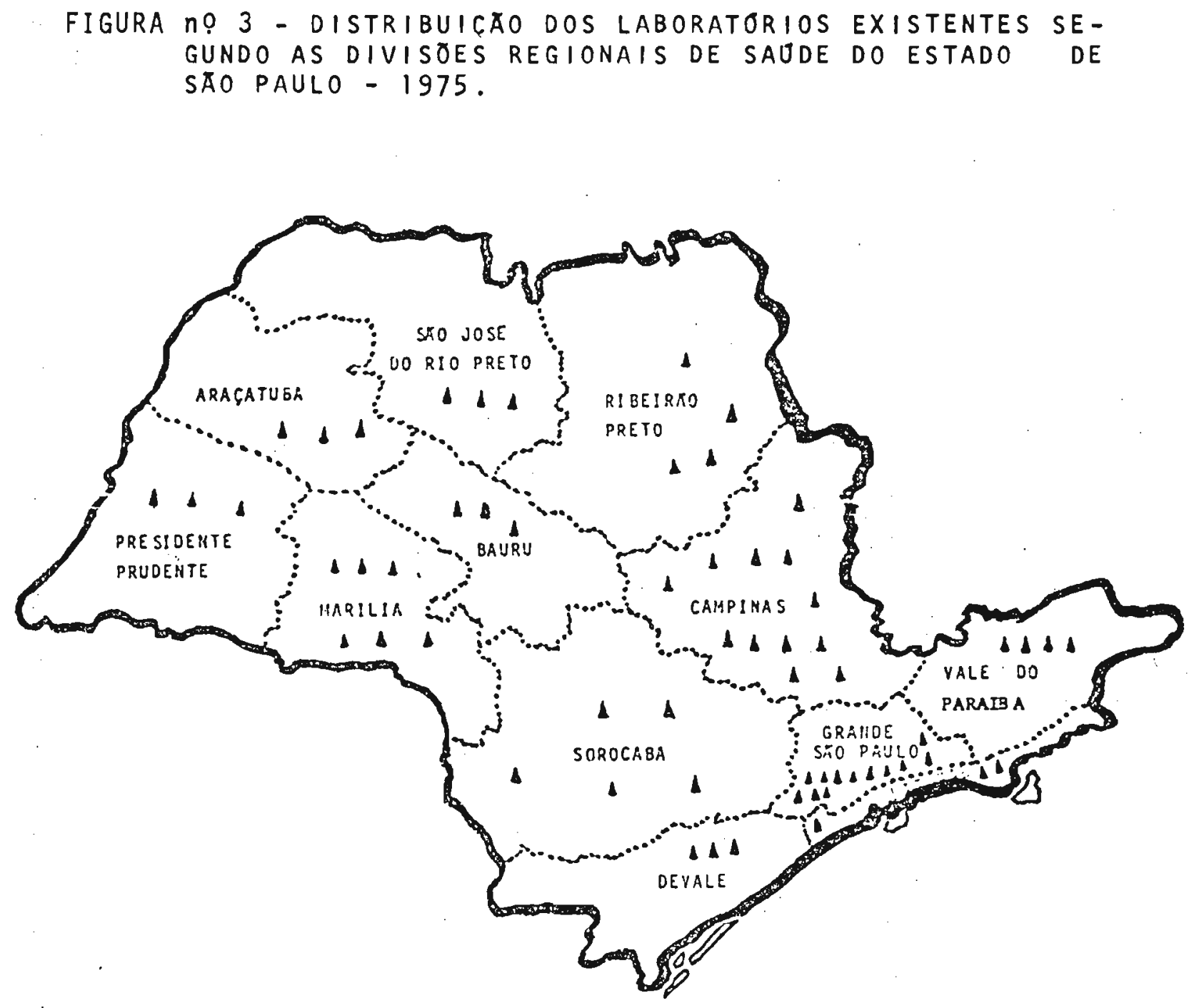

FONTE: Divisāo de Estudos e Programas da Coordenadoria de Saúde da Comunidade e Instituto Adolfo Lutz da Secre taria da Saúde do Estado de São Paulo. 
6. IMPLANTAÇAO DA REDE DE LABORATORIOS DE BACTERIOLOGIA DE TUBERCULOSE NO ESTADO DE SAO PAULO

\subsection{CONSIDERAÇOES GERAIS}

0 momento epidemiológico atual indica a implanta ção quase que imediata da Rede de Laboratōios de Bacterio logia de Tuberculose em todo o Estado.

Não hã dūvida que os métodos diagnósticos, empre gados atualmente, cobrem uma parcela muito pequena da popu lação e se limitam apenas às āreas urbanas. Praticamente inexiste programa de descoberta de casos nas regiões rurais e nos municipios com população abaixo de 20.000 habitantes ${ }^{43}$.

Realizar um programa de descoberta de casos baseado unicamente na radiologia seria impraticável, altamen te oneroso, pouco rentāvel e não atingiria o objetivo bãs co do programa, que é descobrir casos de tuberculose. Isto, no entanto, não significa que devemos abolir os recursos radiológicos e trocā-los pelos bacteriológicos, mas apenas limitā-los em número e dirigi-los somente a grupos selecio nados.

Recomenda-se que maior ēnfase deva ser dada aos 
mētodos bacteriológicos, multiplicando-os à medida do possível de maneira permanente elatendendo às reais necessidades da população de todos os municĩpios, nas respectivas zonas urbanas e rurais.

Um programa de descoberta de casos baseado principalmente na bacteriologia, atravēs de uma Rede de Labora tōrios, instalada em todo o Estado, seria perfeitamente viá vel e exequivel, permitindo descobrir os casos mais impor tantes do ponto de vista epidemiológico, ou seja, os casos baciliferos, que representam o maior risco para a comunida de. Através da eliminação dos mesmos, conseguiríamos dimi nuir certamente, e em menor prazo de tempo, o reservatório da infecção em nosso meio.

\subsection{ETAPAS DA IMPLANTAÇAO}

0 processo da implantação e efetivação da Rede de Laboratórios de Bacteriologia no Estado de São Paulo poderā se processar em etapas, evitando-se erros que viriam prejudicar a concretização do mesmo. As funções especīficas de cada laboratório são apresentadas no item relativo às atividades de cada laboratōrio. As três etapas sucedem-se da seguinte forma:

\subsubsection{Primeira Etapa}

obedecendo as seguintes atividades gerais: 
a) Levantar os dados referentes aos estabeleci - mentos de saúde existentes no Estado, vias de comunicação, meios de transporte de mate rial e pessoal disponivel;

b) escolher uma ou mais āreas programāticas pa ra testar a viabilidade e exequibilidade do empreendimento, visando à extrapolação do mētodo a outras āreas;

c) calcular, por estimativa, a prevalência de doentes baciliferos nos municipios da regi ão e determinar o nūmero de Laboratōrios e Postos de Colheita de Amostras necessārios ao atendimento permanente desta população;

d) indicar o Laboratório Central do Estado, bem como os Laboratōrios Regionais e Locais, além dos Postos de Colheita de Amostras, na respectiva ou respectivas āreas de teste;

e) permitir que se realizem somente em nivel Central todas as atividades especificadas ao Laboratório Central situadas no it e m 6.4.1. deste capitulo;

f) implantar o sistema iniciando-se por um pro cesso vertical de implantaçāo, isto é, distribuindo-se todo o material necessārio às atividades de diagnóstico a todas as unida des participantes da Rede de uma só vez e no menor tempo possivel.

Somente apōs a concretizaçāo e dinamização da Prị meira Etapa, é que se deverá prosseguir com a prōxima etapa. 


\subsubsection{Segunda Etapa}

Constarā das seguintes atividades:

a) Estender o processo a outras āreas, ā medida das disponibilidades orçamentārias gover namentais, aproveitando as experiencias adquiridas na ārea programātica. Nas novas ā reas escolnidas o processo deverá iniciarse pela Primeira Etapa descrita anteriormen te, excluindo-se apenas o item (b) e a indi cação do Laboratōrio Central, no item (d);

b) Atribuir aos Laboratōrios Regionais as funçōes especificadas no item 6.4.2.1. deste capitulo, referentes à Segunda Etapa.

\subsubsection{Terceira Etapa}

Na Terceira Etapa poderão ser realizadas as seguintes atividades:

a) Estender o processo a outras āreas, completando assim todo o Estado, aproveitando as experiēncias anteriores e iniciando-se pela Primeira Etapa, excluindo apenas o item (b) e a indicação do Laboratōrio Central, no item (d) ;

b) Cónferit aos Laboratórios Regionais, que ainda não executam as funçōes específicas da Segunda Etapa, a autorização de executā-las;

c) Atŕribuir aos Laboratōrios Locais as funçōes especificadas no item 6.4.2.2. deste capitu 10 , referentes à Segunda Etapa. 
Todas estas etapas não representam diretrizes exatas para a concretização da Rede He Laboratórios de Bacteriologia da Tuberculose no Estado de São Paulo, mas ape nas simples sugestōes do autor, no sentido de obter o máximo do benefício de um mētodo diagnōstico (no caso, a bac teriologia) em prol da realização de um dos objetivos do programa de controle da tuberculose, que é adescoberta de casos, ou seja, fundamentalmente, localizar os tuberculosos baciliferos.

Entretanto, as medidas efetuadas para a descober ta de casos não podem de maneira alguma ser desvinculadas das medidas referentes ao tratamento ${ }^{20}$. Qualquer plano que se faça em torno de atividades de descoberta de casos implicaria, conseqdentemente, na introdução de um plano concomitante de todo o caso descoberto. Atividades e custos sobre o tratamento, no entanto, fogen ao escopo deste trabalho.

\subsection{ESTRUTURA DA REDE DE LABORATORIOS}

- Estado de São Paulo dispõe de um grande nūmero de laboratórios que poderão perfeitamente satisfazer as exigências da Rede, dos quais destacam-se os laboratōrios pertencentes à Coordenadoria de Saúde da Comunidade, localizados em Centros de Saūde tipo I, II, III e IV e distrí buĩdos em todo o Estado; laboratōrios do Instituto Adolfo Lutz, localizados na Capital e em värios municípios do Es- 
tado; laboratōrios pertencentes à Coordenadoria de Assistência Hospitalar; laboratōrio da Disciplina de Tisiologia da Faculdade de Saūde Pūblica da Universidade de São Paulo; laboratórios da Associação dos Sanatorinhos Populares "Campos do Jordão".

A Rede deverā estruturar-se nas bases jā especi ficadas nas Normas para Laboratōrios de Bacterioscopia da Tuberculose" da Divisão Nacional de Tuberculose 9 que, no capitulo referente à estrutura da Rede, aconselha a existência de:

a) um Laboratōrio Central;

b) Laboratōrios Regionais e Locais (serviço Po10);

c) Postos de Colheitas de Amostras (PCA) ou Unidades Satēlites;

d) Laboratōrios Especiais de Bacteriologia da Tu berculose.

O Decreto ne 52.182, de 16 de julho de 196953, atribui à Coordenadoria de Saūde da Comunidade e à Coor denadoria de Serviços Técnicos Especializados a execução de exames laboratoriais, gerando ambigulidade de atribui ções. A solução prātica a curto e médio prazo poderia ser obtida atravēs de um sistema que possa evitar confli tos de mando, funções e atividades para a implantação do processo. 


\subsection{FUNGOES DE CAOA LABORATORIO}

\subsubsection{OLaboratōrio Central}

Localizado na Capital do Estado, servirā de suporte tēcnico científico às atividades prelimina res da ārea-piloto, como tambēm à introdução da Re de de Laboratōrios em todo o Estado.

Deverā realizar todas as tarefas bāsicas atribuídas a um Laboratório Central, ou seja:

a) baciloscopia, cultivo, testes de resistēncia, e deve dispor de meios para tipagem de micobactérias, quando solicitado;

b) supervisão (direta e indireta) dos Laborató rios Regionais;

c) adestramento de pessoal, dos Laboratórios Regionais e eventualmente Laboratórios Locais ;

d) estatistica qualitativa e quantitativa de exames realizados no Estado;

e) distribuiçāo de reativos, potes e outros materiais aos Laboratórios Regionais;

f) coordenar os serviços regionais do Estado para remessa de amostras.

Caso o Laboratōrio Central não possa exer- 
cer todas as funções especificadas, tais responsabilidades seriam distribuidas a outras Unidades, em carāter temporārio, e que estejam em condições de executã-las.

\subsubsection{Laboratōrios Regionais e Locais}

\subsubsection{OS LABORATORIOS REGIONAIS - que no caso do Estado de São Paulo se 10- calizarão nos distritos sede de município de cada Divisão Regional de Saúde, terão na primeira etapa da implantação as seguintes funções específicas:}

a) realizar exame microscōpico direto das a mostras enviadas pelos respectivos PCA;

b) encaminhar ao Laboratório Central as amostras para exames mais especializados;

c) recolner as informações estabelecidas e remetē-1as, periodicamente, ao Laboratório Central do Estado.

Na segunda etapa da implantação, os Laboratōrios Regionais poderão executar fun çōes mais amplas, tais como:

a) realizar exame microscōpico direto e cul tura das amostras e, se possivel, testes de resistência enviados pelos PCA; 
b) distribuir potes, reativos e outros mate riais aos Laboratörios Locais;

c) fazer supervisão (direta e indireta) dos Laboratórios Locais;

d) treinar pessoal dos Laboratōrios Locais nos prōprios Distritos Sanitārios;

e) recolher as informaçōes estatisticas e enviā-las ao Laboratōrio Central.

6.4.2.2. Os LABORATORIOS LOCAIS - tambēm de nominados Serviços Polo, localizados nos diversos municípios, realizarão na primeira etapa da implantação apenas a baci loscopia direta do escarro, tanto da sua $\bar{a}-$ rea de ação como dos materiais enviados pe los respectivos PCA. Na segunda etapa pode rāo executar funções como:

a) realizar cultura de amostras enviadas pe los respectivos $P C A$;

b) distribuir potes reativos e outros materiais aos PCA;

c) treinar pessoal dos respectivos PCA;

d) fazer a supervisão dos PCA.

6.4.3. Os Postos de Colheita de Amostras (PCA) 
se-ão em serviços que não possuam laboratōrios. Su a função específica serā apenas de colher adequadamente a amostra e enviā-la ao Laboratōrio Local ou Regional correspondente.

6.4.4. Laboratōrios Especiais de Bacteriologia da Tuberculose

Pertencentes a sanatórios, hospitais gerais e especializados, ou estabelecimentos de ensino ou pesquisa no setor de Tisiologia Sanitāria, poderão integrar-se na Rede, visando cooperar com o Labora tōrio Central.

\subsubsection{Escolha da Area Programātica}

O objetivo bāsico da escolha de uma ārea pro gramātica ē, sem dūvida, a obtenção de uma ārea de referência onde se possa realizar um determinado en saio, de forma que se possa adaptā-lo a toda uma região ou Estado. Essa ārea servirā de campo expe rimental a uma sērie de variāveis que atuam sobre um programa ou ação. As experiências adquiridas serão avaliadas, ajustadas e finalmente extrapoladas a todo o Estado.

Nosso trabalho não foi realizado numa ārea programātica representativa, que seria ideal em ter 
mos de Estado, mas se baseou nas facilidades de obtenção de dados reais levantados anteriormente por ARANTES ${ }^{3}$ quando escolheu a Divisão Regional de Ribeirão Preto (DRS-6) para fazer um estudo de in tegração das atividades antituberculose nas Unidades Sanitārias do Estado de São Paulo.

Os capitulos subsequentes relatam o estudo das diversas fases que podem ser utilizadas para o processo da implantação de uma Rede de Laboratórios de Bacteriologia da Tuberculose, na DRS-6, sa lientando sua estrutura administrativa em saúde, po pulação, superficie, recursos laboratoriais existentes, atividades referentes ao diagnōstico, pre vendo a efetivação do processo, atravēs da criação de laboratōrios regionais e locais, alēm de postos de colheita de amostras. Algumas contribuições são trazidas no que se refere a treinamento de pessoal, material, custo, supervisão e avaliação da metodologia empregada.

6.5. ESTUDO PRELIMINAR PARA A IMPLANTAÇAOO DE UMA REDE DE LABORATORIOS DE BACTERIOLOGIA DA TUBERCULOSE NA DIVISAO REGIONAL DE SAUDE DE RIBEIRAO PRETO - DRS-6

Para que este estudo sobre a implantação da Rede se processasse, uma sērie de informaçōes bāsicas foi levan tada, obedecendo a seguinte ordem: 
1 - nome e população do municīpio sede da ärea programātica;

2 - nome e população dos municīpios que compōem a DRS -6 , que não a sede;

3 - distribuição dos distritos sanitārios e respecti vos municipios;

4 - vias de comunicação visando:

a) ao transporte de amostras dos respectivos PCA aos Laboratórios Locais;

b) à distāncia entre os Laboratōrios Locais e o Laboratōrio Regional;

c) à distāncia entre o Laboratōrio Regional e o Laboratōrio Central ;

5 - Categoria e número do pessoal existente nos diversos laboratórios e nas diversas Unidades Sani tārias, que possa ser posteriormente treinado;

6 - laboratōrios existentes na região, pertencentes à Secretaria da Saúde do Estado de São Paulo;

7 - Obtenção do municīpio de procedencia dos casos notificados pela DRS-6 nos anos de 1969, 1970, 1971 ;

8 - atendimento à população efetuado pelos diversos Centros de Saúde existentes (percentual da deman da estimada);

9 - serviços de saúde existentes na ārea e sua respectiva categoria;

10 - material permanente existente na DRS-6. 
Mediante as informaçōes obtidas nos primeiros oi to itens, foi possível quantificar a população em estudo, o nümero de baciloscopias que deverão ser realizadas, e fi nalmente estabelecer os diversos Laboratórios e Postos de Colheita de Amostras (PCA) que farão parte da Rede.

As experiēncias advindas deste estudo não trazem uma metodologia nova de aplicação, mas algumas diretrizes bāsicas que podem auxiliar, no futuro, a continuidade do processo.

6.5.1. Estrutura Administrativa da DRS-6 e Respectivos Municipios

A Divisão Regional de Saūde de Ribeirão Pre to - DRS -6 , apresentada nas FIGURAS n:s. 4,5 e 6, estā dividida em 10 sub-regiōes, ou seja, dis tritos sanitários, totalizando 82 unidades sanitarias, sendo 5 do tipo I, 6 do tipo II, 10 do tipo III, 18 do tipo IV e 43 do tipo V. A popula ção estimada para 1975 ẽ de 1.459 .676 habitantes, distribuĩda numa ārea de $36.625 \mathrm{~km}^{2}$ (dados obtidos junto à Divisão de Estudos e Programas da Coordena doria de Saúde da Comunidade da Secretaria da Saúde do Estado de São Paulo).

Os municĩpios, a população e respectivos tị pos de Unidades Sanitārias se distribuem de acordo com a TABELA n: 3 . 


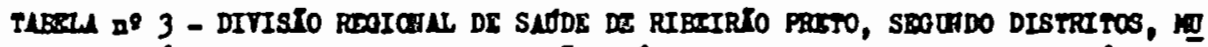



\begin{tabular}{|c|c|c|c|c|}
\hline & H $U$ U H $I$ C C I I P 1 & POPULACAO & $K M^{2}$ & $\begin{array}{l}\text { TIPO DE UNI- } \\
\text { DADE SANITA- } \\
\text { RIA. }\end{array}$ \\
\hline  & $\begin{array}{l}\text { Barrinha } \\
\text { Cravinhos } \\
\text { oumont } \\
\text { Luis Antonio } \\
\text { Pontal } \\
\text { Pradopolis } \\
\text { Ribeirá Preto } \\
\text { Sta.Rosa do Viterbo } \\
\text { Sa o Sinão } \\
\text { Serra Azul } \\
\text { Serrana } \\
\text { Sertazozinho }\end{array}$ & $\begin{array}{r}8.682 \\
13.145 \\
2.451 \\
1.955 \\
13.014 \\
5.876 \\
250.228 \\
11.399 \\
11.595 \\
4.462 \\
9.192 \\
31.760\end{array}$ & $\begin{array}{r}141 \\
313 \\
68 \\
639 \\
394 \\
162 \\
1.057 \\
287 \\
634 \\
279 \\
128 \\
418\end{array}$ & $\begin{array}{ll}V \\
I V \\
V \\
V \\
I V \\
Y \\
I I-I V \\
I V \\
V \\
V \\
V \\
I I\end{array}$ \\
\hline 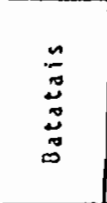 & $\begin{array}{l}\text { Altinopolis } \\
\text { Eatatajs } \\
\text { Brodosqui } \\
\text { Cajuru } \\
\text { Cassia dos Coquelros } \\
\text { Sardinopolis } \\
\text { Sto.Antonio da Alegria }\end{array}$ & $\begin{array}{r}10.235 \\
28.560 \\
7.784 \\
12.744 \\
2.422 \\
15.943 \\
4.506\end{array}$ & $\begin{array}{l}943 \\
830 \\
290 \\
796 \\
191 \\
552 \\
306\end{array}$ & $\begin{array}{l}\text { Th } \\
\text { III } \\
\text { In } \\
\text { y } \\
\text { III }\end{array}$ \\
\hline $\begin{array}{l}0 \\
0 \\
0 \\
0 \\
0\end{array}$ & $\begin{array}{l}\text { Cristais Paulista } \\
\text { Franca } \\
\text { Itirapuãn } \\
\text { Patrocinio Paulista } \\
\text { Pedregulho } \\
\text { Restinga } \\
\text { Ribeirăo Corrente } \\
\text { Rifania } \\
\text { Săo Jose da Bela Vista }\end{array}$ & $\begin{array}{r}4.015 \\
114.300 \\
4.137 \\
7.807 \\
13.586 \\
4.700 \\
1.932 \\
7.837 \\
6.128\end{array}$ & $\begin{array}{l}351 \\
590 \\
148 \\
611 \\
727 \\
240 \\
163 \\
158 \\
286\end{array}$ & $\begin{array}{l}\text { V } \\
I \\
Y \\
\text { IV } \\
\text { IV } \\
\text { IV } \\
\text { IV } \\
y \\
y\end{array}$ \\
\hline $\begin{array}{l}0 \\
3 \\
2 \\
5 \\
3 \\
3 \\
\vdots\end{array}$ & $\begin{array}{l}\text { Aramina } \\
\text { Buritizal } \\
\text { Guara } \\
\text { Igarapara } \\
\text { I turerava } \\
\text { lliguelopolis } \\
\text { Jeriquara }\end{array}$ & $\begin{array}{r}5.274 \\
6.130 \\
12.334 \\
18.793 \\
26.539 \\
18.166 \\
1.479\end{array}$ & $\begin{array}{l}194 \\
253 \\
348 \\
452 \\
727 \\
837 \\
137 \\
\end{array}$ & $\begin{array}{l}\text { Y } \\
y \\
\text { IV } \\
\text { II } \\
\text { II } \\
\text { IV } \\
\text { IY }\end{array}$ \\
\hline 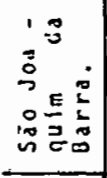 & $\begin{array}{l}\text { Ipua } \\
\text { iorro igudo } \\
\text { duporanga } \\
\text { orlandia } \\
\text { Sales de ol fvelra } \\
\text { são Joaquim da Barra }\end{array}$ & $\begin{array}{r}8.925 \\
1: .765 \\
5.293 \\
20.950 \\
6.179 \\
25.173 \\
\end{array}$ & $\begin{array}{r}457 \\
351 \\
341 \\
305 \\
293 \\
397 \\
\end{array}$ & $\begin{array}{l}\text { IV } \\
\text { İ: } \\
\text { IV } \\
\text { II } \\
\text { III }\end{array}$ \\
\hline $\begin{array}{l}n \\
0 \\
0 \\
2 \\
0 \\
0 \\
0\end{array}$ & $\begin{array}{l}\text { Barretos } \\
\text { Colina } \\
\text { Colombia } \\
\text { Guaira } \\
\text { Jaborands }\end{array}$ & $\begin{array}{r}64.953 \\
9.736 \\
3.530 \\
28.575 \\
4.670 \\
\end{array}$ & $\begin{array}{r}1.527 \\
938 \\
1.201 \\
254 \\
\end{array}$ & $\begin{array}{l}\text { II } \\
\text { IV } \\
\text { II } \\
y\end{array}$ \\
\hline $\begin{array}{l}0 \\
0 \\
0 \\
0 \\
0 \\
0 \\
0 \\
0 \\
0\end{array}$ & $\begin{array}{l}\text { Fernando Prestes } \\
\text { Candido Rodrigues } \\
\text { Guariba } \\
\text { Jaooticabal } \\
\text { lionte Alto } \\
\text { sta. Ernestina } \\
\text { Taquaritingd } \\
\text { Vista Alegre do Alto }\end{array}$ & $\begin{array}{r}3.928 \\
2.133 \\
12.220 \\
39.734 \\
23.119 \\
3.220 \\
28.867 \\
2.019 \\
\end{array}$ & $\begin{array}{l}140 \\
294 \\
274 \\
677 \\
311 \\
130 \\
530 \\
78 \\
\end{array}$ & $\begin{array}{l}y \\
y \\
\text { III } \\
\text { II } \\
\text { III } \\
y \\
\text { il } \\
y \\
\end{array}$ \\
\hline $\begin{array}{l}0 \\
\vdots \\
3 \\
0 \\
0 \\
0 \\
0 \\
0 \\
0\end{array}$ & $\begin{array}{l}\text { Bebedouro } \\
\text { ilonte Azul Paulista } \\
\text { piranji } \\
\text { Pitanguedras } \\
\text { iafacu } \\
\text { Taiuva } \\
\text { Terra Roxa } \\
\text { Viradouro }\end{array}$ & $\begin{array}{r}39.396 \\
10.097 \\
4.916 \\
15.241 \\
2.871 \\
3.704 \\
4.397 \\
8.214\end{array}$ & $\begin{array}{l}723 \\
2.51 \\
180 \\
528 \\
108 \\
124 \\
223 \\
195\end{array}$ & $\begin{array}{l}I l \\
y \\
y \\
I y \\
y \\
y \\
y \\
y\end{array}$ \\
\hline $\begin{array}{l}0 \\
0 \\
3 \\
0 \\
0 \\
0 \\
0 \\
2 \\
2\end{array}$ & $\begin{array}{l}\text { Américo Brasflifense } \\
\text { Araraquara } \\
\text { ioa Esperenca do sul } \\
\text { Borboretna } \\
\text { Dobrada } \\
\text { Ibttinga } \\
\text { Itapolis } \\
\text { Hatao } \\
\text { llova Europa } \\
\text { Rincáo } \\
\text { Sta. Lucla } \\
\text { Tobatlnga }\end{array}$ & $\begin{array}{r}6.800 \\
217.228 \\
5.583 \\
8.360 \\
2.642 \\
23.983 \\
19.391 \\
21.552 \\
2.550 \\
6.108 \\
4.481 \\
5.956\end{array}$ & $\begin{array}{r}133 \\
6.584 \\
736 \\
511 \\
160 \\
649 \\
996 \\
537 \\
160 \\
274 \\
150 \\
443\end{array}$ & 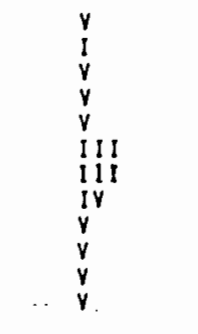 \\
\hline$\because \frac{n}{0}$ & $\begin{array}{l}\text { Descalvado } \\
\text { Dourado } \\
\text { Ibate } \\
\text { Ribeiräo Bonito } \\
\text { Sĩo Carlos } \\
\text { S:a.Rita co Passa Quatro }\end{array}$ & $\begin{array}{r}16.960 \\
5.071 \\
7.455 \\
6.355 \\
94.585 \\
18.114\end{array}$ & $\begin{array}{r}794 \\
209 \\
297 \\
481 \\
1.120 \\
756 \\
\end{array}$ & $\begin{array}{l}\text { IV } \\
y \\
y \\
y \\
I \\
\text { III }\end{array}$ \\
\hline Iotal & - & $1.459 .670^{\circ}$ & 36.625 & 82 \\
\hline
\end{tabular}

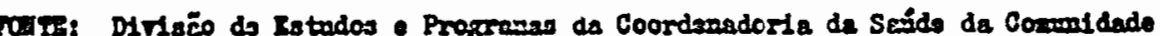
da Soeretaria de Scrído do Eatado do Sáo Paulo. 
FIGURA NO 4 - LOCALIZACAO DA DIVISAO REGIONAL DE SAO DE DE RIBEIRAO PRETO NO ESTADO DE SAO PAULO= 1975

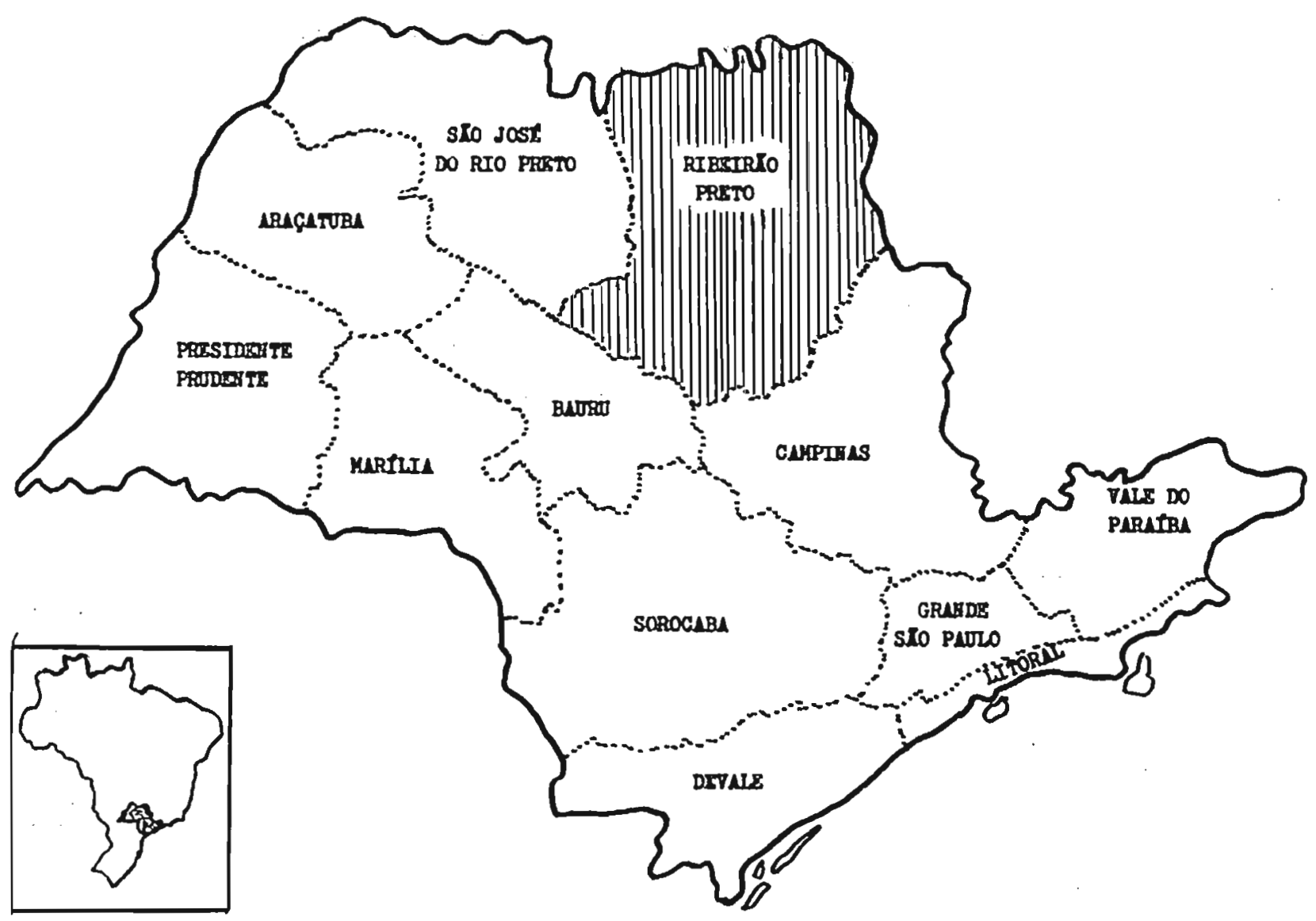

FONTE: Divisāo de Estudos e Programas - Coordenadoria de Saüde da Comunidade, Secretaria da Saúde do Esta do de São Paulo. 
FIGURA nO 5 - DIVISAOO REGIONAL DE SAUDE DE RIBEIRAO PRETO, SEGUNDO DISTRITOS E MUNICIPIOS.



FONTE: Divisāo Regional de Saüde de Ribeirāo Preto. 
FIGURA $I O Q 6$ - DIVISAO REGIONAL DE SAODE DE RIBEIRÃO PRETO, SEGUNDO VIAS DE TRANSPORTE (Asfaltadas) - 1975.

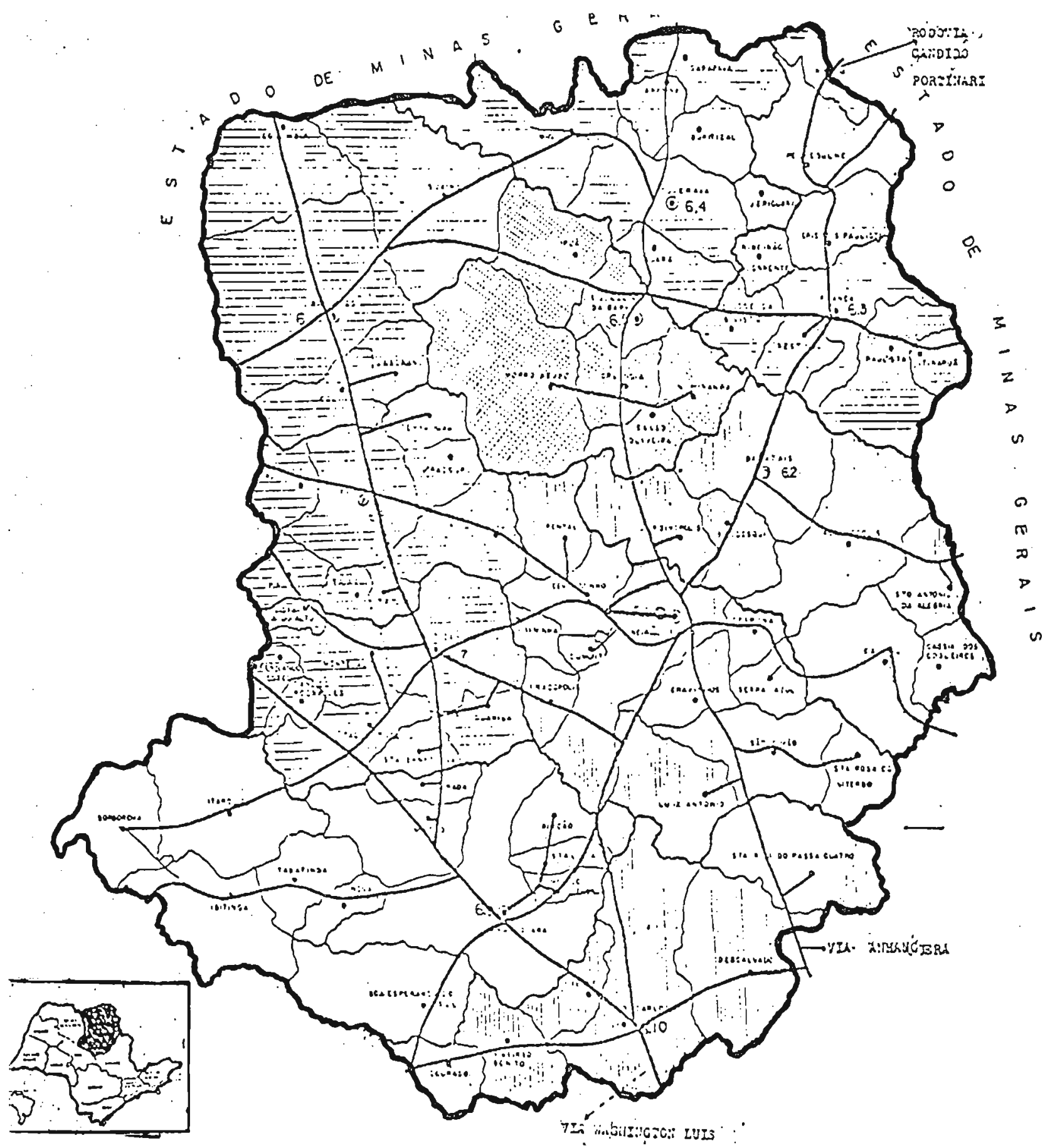

FonTE: Divisão Regional de Saüde de Ribeirāo Preto. 


\subsubsection{População Onde Devem ser Procurados os Ca-} sos de Tuberculose

\subsubsection{Considerações Gerais}

Uma das finalidades dos programas de controle da tuberculose é cortar a cadeia de transmissão do agente etiolōgico. Isto significa, em outras palavras, descobrir os casos de tuberculose na comunidade e submetê-los ao tratamento adequado. Não existe dūvida quando se afirma que o doente que representa maior risco para a comunidade, é aquele em cujo escarro forem evidenciados bacilos da tuberculose pelo exame mi croscöpico 36 .

Conclui-se, portanto, que todo in-

dividuo que possui escarro bacteriologicamen te positivo (positivo ao exame direto ou so mente à cultura) ē potencialmente uma fonte de transmissão da doença.

Estudos realizados por RAJ MARAIN ${ }^{4}$, GRZYBOWSKI, BARNETT E STYBLO 24 , salienta dos no capitulo 2 deste trabalho, enaltecem a importância dos casos de tuberculose, ou seja, dos individuos bacteriologicamente confirmados, que do ponto de vista epidemio 
lógico representam a população prioritāria dos programas de controle da moléstia.

Todo o mētodo diagnóstico destinado à descoberta de casos de tuberculose de verā objetivar basicamente uma população que proporcione o encontro de uma alta taxa de casos de tuberculose. Estudos realizados por LARBAQUI 30 na Algēria, NAGPAUL e col.40 na India, SENTIES 55 no México, demonstram que os pacientes com sintomatologia respira tōria (sintomāticos respiratōrios), ou seja, pacientes com tosse e expectoração por periodo superior a 2 ou 3 semanas, represen tam a população que proporciona o maior nūmero de casos de tuberculose.

$$
\text { NAGPAUL e col. } 40 \text { salientaram ain- }
$$

da a importância do tempo de duração dos sin tomas, relacionando-os com o grau de positi vidade obtido (TABELA n: 4).

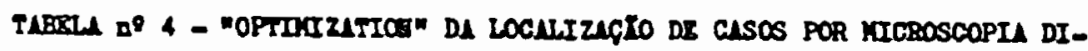
RIST EM PESSOLS CON SIITOMLS RISPIRLTORTOS (IHDTA)

\begin{tabular}{|c|c|c|c|c|}
\hline $\begin{array}{l}\text { PESSOLS COH SIITOSUS RTSPIRL } \\
\text { TORIOS }\end{array}$ & $\begin{array}{l}\text { H8 DB } \\
\text { PESSOLS }\end{array}$ & $\$$ & $\begin{array}{l}\text { B. CASOS E/ES } \\
\text { CARRO POSITIV }\end{array}$ & $\$$ \\
\hline $\begin{array}{l}<14 \text { dias } \\
\text { duragä } \\
>14 \text { dias } \\
\text { duragao }\end{array}$ & $\begin{array}{l}241 \\
381\end{array}$ & $\begin{array}{l}33,2 \\
52,6\end{array}$ & 43 & $\begin{array}{r}2,2 \\
95,5\end{array}$ \\
\hline $\begin{array}{l}\text { Pessose con tosse descobertas } \\
\text { por un entroristador }\end{array}$ & 101 & 13,9 & 1 & 2,2 \\
\hline Pessoas con dor torádce .... & 1 & 0,3 & - & - \\
\hline- TOT $\triangle 2 \ldots .$. & 724 & 100,0 & 45 & 100,0 \\
\hline
\end{tabular}

TOITE: BLCPLIL, D.R. ot al. (40). 
Os pacientes que apresentam sintomatologia respiratória por mais de duas a trēs semanas representam, portanto, a população prioritāria para a descoberta de casos de tuberculose.

Para que se realizem medidas diagnōsticas baseadas nos mētodos bacteriológicos, tem-se necessidade de estimar o nūmero de sintomāticos respiratórios presentes em uma determinada população, dos quais se pode avaliar o número de bacilíferos. Por ou tro lado, os casos baciliferos podem ser es timados atravēs de mêtodos indiretos, como - risco anual da infeç̧ão, obtido por levan tamentos da prevalência da infecção tubercú losa numa população.

6.5.2.2. Estimativa do Número de Casos de Tuberculose Pulmonar

A estimativa do número de casos de tuberculose pulmonar em uma comunidade pode rá ser efetuada através de dois métodos:

6.5.2.2.1. Conhecimento dos sintomáticos do Aparelho Res piratōrio

o número de casos de tụ 
berculose pulmonar em uma determinada comunidade pode ser calculado atravēs de amos tra dos sintomāticos respiratórios, que com parecem para consulta nas Unidades Sanitárias da região, e dos casos bacteriologica mente positivos, que advêm destes sintomāti cos. Esta amostra permite calcularoper centual de sintomáticos e de casos, sabendo-se que os mesmos variam consideravelmente de região para região. Estudos realiza dos na ārea piloto de Puebla (México) ${ }^{56}$ de monstraram que o percentual de sintomáticos respiratórios crōnicos variou nessa região de 0,9 a $5,1 \%$, enquanto o percentual de ca sos entre os mesmos esteve entre 2,1 a $22,2 \%$.

Pesquisas efetuadas em alguns paĩ ses da América do Sul e Centra $7^{49}$ mostrama proporção de sintomāticos respiratórios entre os maiores de 15 anos que compareceram aos estabelecimentos gerais de saūde para a primeira consulta, nos anos de 1972 e 1973, conforme TABELA ne 5, indicando a prevalēncia de tuberculose pulmonar (bacteriologica mente positiva) nos mesmos pacientes (TABELA n: 6). 
TABELA nQ 5 - PROPORÇÃO DOS SINTOMÁTICOS RESPIRATÓRIOS EN TRE OS CONSULTANTES DE PRTMEIRA VEZ EM ESTABELECIMENTOS GBRAIS DE SAODE EM SEIS PAISES - 1972/1973

\begin{tabular}{|c|c|c|c|}
\hline PAIS & LOCAL & $\%$ & OBSERVAÇOES \\
\hline -Bolfvia.. & todo o Paíz & 10,0 & $\begin{array}{l}\text {-Estimativa. Não so especi } \\
\text { fica a definiçáo de sinto } \\
\text { mático respiratório. }\end{array}$ \\
\hline -BRASII... & Sta Catarina & 13,4 & $\begin{array}{l}\text {-Consultantes do } 15 \text { anosar } \\
\text { mais. }\end{array}$ \\
\hline -Colómbia. & Dte Quindio & 6,8 & $\begin{array}{l}\text {-Consultantes de } 15 \text { anosou } \\
\text { mais. }\end{array}$ \\
\hline ' & Dte Rioaralda & 10,1 & $\begin{array}{l}\text {-Consultantes de } 15 \text { anos a } \\
\text { mais. }\end{array}$ \\
\hline -Cuba .... & todo o Paí & 0,6 & $\begin{array}{l}\text {-Conoultantes de } 15 \text { anosca } \\
\text { maig. com tosse e expecto } \\
\text { raçá de mais de trés se- } \\
\text { manas de duraçäo. }\end{array}$ \\
\hline -Honduras. & todo o País & 5,0 & $\begin{array}{l}\text {-Estimativa. Näo se especi } \\
\text { fíca a definiçáo de sinto } \\
\text { mático roopiratório. }\end{array}$ \\
\hline -Peru .... & Lima & 9.4 & $\begin{array}{l}\text {-Consultantes de } 15 \text { anos a } \\
\text { mais. }\end{array}$ \\
\hline
\end{tabular}

PONTE: Organizaçäo Panamorica da Saúde (49). 
TABELA no 6 - PREVAL BNCIA DE TUBERCULOSE PULMONAR BACTERIO LOGICAMENTE POSITIVA ENTRE CONSULTANTES DE PRIMEIRA VEZ, MAIORES DE I5 ANOS, COM SINTOMAS RESPIRATORIOS, EM OITO PAISES DA AMERICA LATINA - 1972/1973

\begin{tabular}{l|l|l}
\hline PIS & LOCAL & $\%$ \\
\hline
\end{tabular}

- Argentina ....... coporra do Pogo

- Bolivia ......... -Todo o Pala

10,0

- BRASIl
- Estado do Rio do Janeiro

7,0

- Fundação SESP

8,1

osanta Catarina

9.4

- Colómbia (....... -Dtr Quindio

7.6

-Den Risaralda

- Caba

- Todo o Paía

1,3

- Guatorala

-Regiõez Sanitáriag $I V \odot V$

7,9

- Hondaras ........ -Todo o País 5,5

- Peru ........... - -Lima

6,2

- Tacna

7.7

PONTE: Organização Panamericana da Saúdo (49). 
o cālculo do percentual de casos na população examinada ē feito da seguinte maneira:

a) quantificar o nūmero de consultas gerais de pacientes de maiores de 15 anos que consultam pela primeira vez na Unidade Sanitāria e calcular percentualmente o nūmero de sintomāticos respiratórios existentes entre os consultantes.

EXEMPLO :

Nümero de consultas .........8 8.000

Numero de pacientes com sintomas respiratörios .............. 800

Percentual $\ldots \ldots \ldots \ldots \ldots \ldots$........

b) Entre os pacientes sintomāticos respiratórios pesquisar o nūmero de casos bacte riologicamente confirmados e calcular a porcentagem dos mesmos.

EXEMPLO:

Nümero de sintomáticos ....... 800

Nümero de casos ............ 80

Cálculo percentual $\ldots \ldots \ldots \ldots$ 10\%

Isto significa que, num total de 8.000 consultas gerais iniciais, $10 \%$ foram de pacientes com sintomatologia respiratōria, obtendo-se dā $10 \%$ de casos de tuberculose ou $1 \%$ do total de pacientes examina dos.

Entretanto, fixar o número de baci 
1 îferos atravēs do número de consultas gerais é muitas vezes difícil, por não existir ainda uma conduta sistemātica dirigida à pesquisa dos sintomāticos respiratórios que comparecem às unidades sanitārias para exame de saúde. Praticamente inexistem dados estatisticos do Estado de São Paulo re lacionando nūmero de consultas gerais, percentual dos sintomāticos respiratörios e nū mero de casos de tuberculose provenien tes destes sintomāticos.

SENTIES e col.56 são categóricos ao afirmar que "estimar a proporção de sin tomāticos respiratōrios crōnicos na ausēncia de estatisticas de consultas gerais nos serviços de saūde ē um processo que dā resultados arbitrārios", e ainda, concluem a firmando que "fixar a proporção de pessoas sintomāticas crōnicas que devem ser examina das, é um dos pontos mais dificeis do programa e somente à medida que o mesmo se estenda, cobrindo um grande nūmero de centros de saūde, serā possīvel determinā-la com certo grau de exatidão".

\subsection{Risco anual de infeç̧ão}

0 nümero de pessoas in- 
fectadas é proporcional ao número de doentes baciliferos existentes numa população. Desta maneira pode-se estimar indiretamente o nūmero de doentes bacilíferos através do número de pessoas infectadas.

Estudos efetuados por STYBLO e SUTHERLAN 58 estimam indices epidemiológicos de tuberculose em países de baixa e alta prevaléncia, mostrando taxas de meningite tuberculo sa e casos com escarro positivo, calculadas atravës do risco anual da infeç̧ão. A TABE LA $n: .7$ apresenta esses dados.

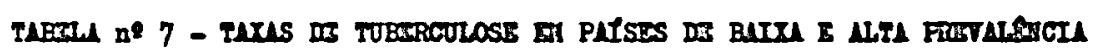

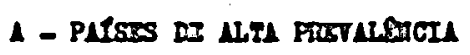



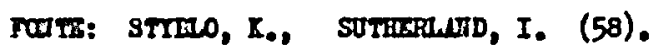


Baseados em dados conhecidos dos in dices de prevaléncia da infecção tuberculosa, obtidos por CERTAIN e col.15, RUFFINONE TO e ARANTES ${ }^{51}$, poderemos situar o Estadode São Paulo como possuindo um risco anual de infecção aproximado de $1 \%$ e dai procedermos ao cālculo do nūmero estimativo de casos (incidência anual). Exemplificando, podere mos extrapolar os dados da TABELA $n$ : 7 reproduzindo estimativamente o risco anual de infecção e a incidência anual aproximada pa ra o nosso Estado, da seguinte maneira:

\begin{tabular}{|c|c|c|}
\hline \multirow[b]{2}{*}{$\begin{array}{l}\text { RISCO ANDAL } \\
\text { DA INPECCR̃O }\end{array}$} & \multicolumn{2}{|c|}{$\begin{array}{l}\text { INCIDENCIA ANOAL APROXIMADA } \\
\text { (por } 100.000 \text { habitantes) }\end{array}$} \\
\hline & $\begin{array}{l}\text { MEN IHGITE } \\
\text { TUBERCULOSA } \\
(0.4 \text { anos })\end{array}$ & $\begin{array}{l}\text { CASOS DE ESCAR } \\
\text { RO POSITIVO (to } \\
\text { das as Idades) }\end{array}$ \\
\hline $1 \%$ & 5 & 60 \\
\hline
\end{tabular}

ou seja, 60 casos de escarro positivo para 100.000 habitantes, o que corresponde a uma taxa de incidência de $0,06 \%$. Conhecida a in cidência, a prevalēncia dos casos com escar ro positivo seria, segundo STYBLO e SUTHERLANO ${ }^{58}$, duas vezes maior, is to ē, $0,12 \%$. No entanto, para o Estado de São Paulo, o cālcu lo da prevalēncia pode ser estimado multi plicando-se a incidēncia por $2,5^{\star}$, isto é, $0,15 \%$.

*Comunicação pessoal do Or. Jaime Santos Ne ves, da Divisão Nacional de Tuberculose. 
6.5.2.3. Estimativa da Prevalēncia de Casos de Tuberculose Pulmonar nos Diversos Municípios pertencentes à DRS -6

Como vimos anteriormente, o conhecimento do nūmero de casos de tuberculose é extremamente dificil e, por mais que se façam cālculos, é impossível predizer, mesmo por aproximação, os casos que poderiam ser encontrados em uma determinada ārea.

A estimativa da prevalência de casos de tuberculose com escarro positivo dos diversos municípios que compõem a DRS-6 foi baseada no risco anual da infecção, segundo a tabela de indices epidemiológicos publica da por SUTHERLAND e STYBLO ${ }^{58}$. A taxa preco nizada para a incidência anual aproximada de casos com escarro positivo foi calculada e extrapolada para os diversos municipios, le vando-se em conta apenas a demanda estimada dos diversos centros de Saúde que compõem a DRS-6 e não sobre a população real de cada municipio. Entende-se por demanda estimada - nūmero de pessoas de um determinado municĩpio que necessita do centro de Saúde de sua respectiva ārea, para obter orientação e cuidados médicos ${ }^{35}$. Dados sobre a popula ção real de cada município, população esti- 
mada em função da demanda e a prevalēncia de casos de tuberculose são publicados na TABELA $n: 8$.

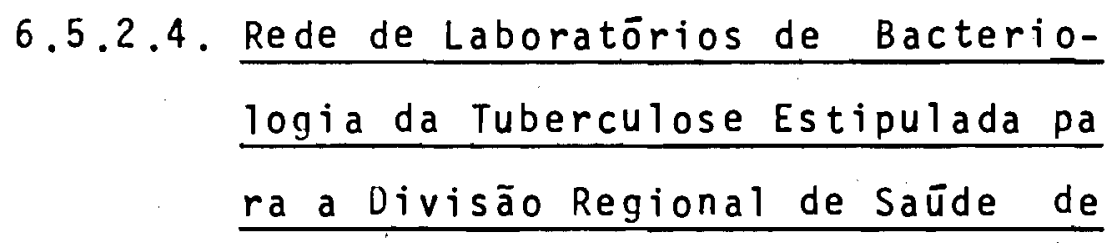
Ribeirão Preto

Mediante a estimativa da prevalência de casos de tuberculose pulmonar (casos ativos) e o número de baciloscopias que de verā ser realizado nos diversos municīpios que compõem a DRS-6, a Rede serā estrutura da, elegendo-se o Laboratōrio do Instituto Adolfo Lutz existente na cidade de Ribeirão Preto, sede da DRS -6 , para desempenhar as funçōes de Laboratōrio Regional da região. Os laboratōrios pertencentes ao Instituto Adolfo Lutz, de Franca e São Carlos, e - Laboratōrio do Serviço Especial de Saūde de Araraquara (SESA) serão designados como Laboratōrios Locais. Para a distribuição dos vārios Laboratórios Locais e Postos de Colheita de Amostras levou-se em conta os seguintes critērios:

a) nūmero de casos estimados e baciloscopias a serem efetuadas; 


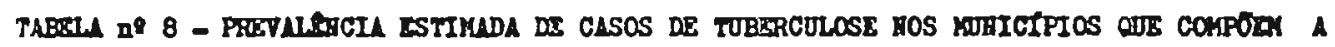
DRS-6, BASELDA HO PERCETTOLL DA DEHTDA ESTIHLDA

\begin{tabular}{|c|c|c|c|c|c|}
\hline & MU $U$ I C IP I & $\begin{array}{c}\text { ropulaciong } \\
\text { pual(") }\end{array}$ & $\begin{array}{c}\text { Ucmanda is } \\
\text { timada }(*) \\
0\end{array}$ & $\begin{array}{l}\text { Ponulaçõo ks- } \\
\text { triada. }\end{array}$ & $\begin{array}{l}\text { Prevalencla } \\
\text { Eatinada de ca } \\
\text { sos de rubereu } \\
\text { lose. }\end{array}$ \\
\hline 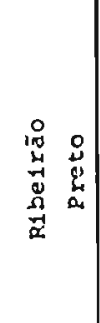 & $\begin{array}{l}\text { Barrinha } \\
\text { Cravinhos } \\
\text { Dumont } \\
\text { Lulg Antonlo } \\
\text { Pontal } \\
\text { pradopolis } \\
\text { Ribelrão Preto } \\
\text { Sta, fosa Viterio } \\
\text { São Simão } \\
\text { Serra nzul } \\
\text { Serrana } \\
\text { Sertaózinio }\end{array}$ & $\begin{array}{r}8.682 \\
13.145 \\
2.541 \\
1.953 \\
13.041 \\
5.876 \\
250.228 \\
11.399 \\
11.595 \\
4.162 \\
9.192 \\
31.760\end{array}$ & $\begin{array}{r}80 \\
80 \\
90 \\
90 \\
70 \\
100 \\
50 \\
90 \\
100 \\
90 \\
90 \\
50\end{array}$ & $\begin{array}{r}6.945 \\
10.516 \\
2.286 \\
1.759 \\
9.128 \\
5.876 \\
125.114 \\
10.259 \\
11.595 \\
4.015 \\
6.272 \\
15.880\end{array}$ & $\begin{array}{r}10 \\
16 \\
3 \\
3 \\
14 \\
10 \\
187 \\
15 \\
17 \\
6 \\
12 \\
23\end{array}$ \\
\hline 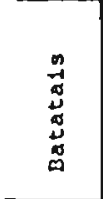 & $\begin{array}{l}\text { Altinopolis } \\
\text { Datatais } \\
\text { Brodoscul } \\
\text { Cajuru } \\
\text { Cassia Los Coruelros } \\
\text { Jardinopolis } \\
\text { Sto.Antonio da Alegria }\end{array}$ & $\begin{array}{r}10.235 \\
28.566 \\
7.784 \\
12.744 \\
2.422 \\
15.943 \\
4.506\end{array}$ & $\begin{array}{l}80 \\
60 \\
90 \\
80 \\
90 \\
60 \\
90\end{array}$ & $\begin{array}{r}8.188 \\
17.139 \\
7.005 \\
10.195 \\
2.179 \\
9.565 \\
4.055\end{array}$ & $\begin{array}{r}12 \\
25 \\
10 \\
15 \\
3 \\
14 \\
6\end{array}$ \\
\hline  & 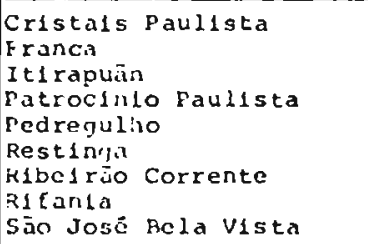 & $\begin{array}{r}4.015 \\
114.3100 \\
4.137 \\
7.087 \\
3.586 \\
4.700 \\
1.932 \\
7.837 \\
6.128\end{array}$ & $\begin{array}{l}90 \\
20 \\
90 \\
80 \\
80 \\
90 \\
90 \\
90 \\
90\end{array}$ & $\begin{array}{r}3.613 \\
22.860 \\
3.723 \\
5.669 \\
10.868 \\
4.230 \\
1.738 \\
7.053 \\
5.515\end{array}$ & $\begin{array}{r}5 \\
34 \\
5 \\
8 \\
16 \\
6 \\
3 \\
10 \\
8\end{array}$ \\
\hline 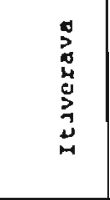 & $\begin{array}{l}\text { Aramina } \\
\text { Buritizal } \\
\text { Guara } \\
\text { Igarapava } \\
\text { rtighna... } \\
\text { Ylguelopolis } \\
\text { Jericuara }\end{array}$ & $\begin{array}{r}5.274 \\
6.130 \\
12.334 \\
18.753 \\
26.530 \\
18.166 \\
1.475\end{array}$ & $\begin{array}{r}100 \\
100 \\
80 \\
100 \\
90 \\
90 \\
100\end{array}$ & $\begin{array}{r}5.274 \\
6.130 \\
9.867 \\
18.793 \\
23.985 \\
16.349 \\
1.479\end{array}$ & $\begin{array}{r}7 \\
9 \\
14 \\
28 \\
35 \\
24 \\
2\end{array}$ \\
\hline  & 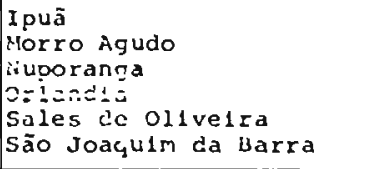 & $\begin{array}{r}8.925 \\
14.775 \\
5.293 \\
20.050 \\
6.179 \\
25.173\end{array}$ & $\begin{array}{r}100 \\
70 \\
60 \\
70 \\
90 \\
65\end{array}$ & $\begin{array}{r}8.925 \\
10.342 \\
3.165 \\
14.675 \\
5.561 \\
16.362\end{array}$ & $\begin{array}{r}13 \\
15 \\
4 \\
22 \\
10 \\
24\end{array}$ \\
\hline $\begin{array}{l}n \\
0 \\
0 \\
0 \\
\\
4 \\
4 \\
0 \\
0\end{array}$ & $\begin{array}{l}\text { Barretos } \\
\text { Colina } \\
\text { Colonbia } \\
\text { Gualra } \\
\text { Jaborand1 }\end{array}$ & $\begin{array}{r}64.953 \\
9.736 \\
3.350 \\
28.575 \\
4.670\end{array}$ & $\begin{array}{l}20 \\
80 \\
90 \\
60 \\
80\end{array}$ & $\begin{array}{r}12.990 \\
7.788 \\
3.015 \\
17.145 \\
3.736\end{array}$ & $\begin{array}{r}19 \\
14 \\
\quad \cdots \quad 4 \\
25 \\
8\end{array}$ \\
\hline $\begin{array}{l}2 \\
0 \\
0 \\
0 \\
0 \\
01 \\
0 \\
0 \\
-3 \\
0 \\
0 \\
0\end{array}$ & $\begin{array}{l}\text { Fernando Prestes } \\
\text { Eandido Podrlques } \\
\text { Guariba } \\
\text { Jaboticabal } \\
\text { lonte Alto } \\
\text { Sta.Ërnestina } \\
\text { racuaritinga } \\
\text { Vista Alegre do Alto }\end{array}$ & $\begin{array}{r}3.928 \\
2.133 \\
12.220 \\
39.734 \\
23.119 \\
3.220 \\
28.867 \\
2.019\end{array}$ & $\begin{array}{l}90 \\
90 \\
50 \\
60 \\
80 \\
90 \\
80 \\
80\end{array}$ & $\begin{array}{r}3.535 \\
1.919 \\
6.110 \\
23.840 \\
18.495 \\
2.898 \\
23.093 \\
1.615\end{array}$ & $\begin{array}{r}5 \\
3 \\
9 \\
35 \\
27 \\
4 \\
35 \\
2\end{array}$ \\
\hline 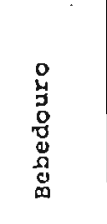 & $\begin{array}{l}\text { Bebedouro } \\
\text { "ionte Azul raulista } \\
\text { Plrangl } \\
\text { Pltanguelras } \\
\text { la1açu } \\
\text { raluva } \\
\text { lerra roxa } \\
\text { Viradouro }\end{array}$ & $\begin{array}{r}39.396 \\
10.097 \\
4.916 \\
15.241 \\
2.871 \\
3.704 \\
4.397 \\
8.214\end{array}$ & $\begin{array}{l}70 \\
80 \\
80 \\
50 \\
60 \\
60 \\
60 \\
60\end{array}$ & $\begin{array}{r}27.577 \\
8.077 \\
3.932 \\
7.620 \\
1.722 \\
2.222 \\
2.638 \\
4.928\end{array}$ & $\begin{array}{r}41 \\
12 \\
6 \\
11 \\
2 \\
3 \\
4 \\
7\end{array}$ \\
\hline 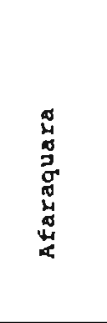 & 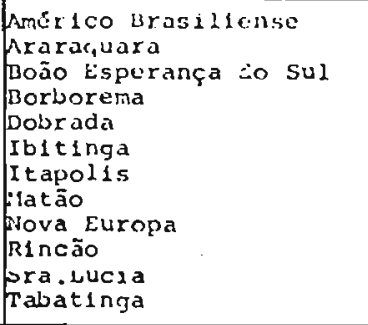 & $\begin{array}{r}6.800 \\
107.689 \\
5.583 \\
8.360 \\
2.642 \\
23.983 \\
19.391 \\
21.552 \\
2.550 \\
6.108 \\
4.481 \\
5.956\end{array}$ & $\begin{array}{r}90 \\
80 \\
100 \\
90 \\
90 \\
80 \\
90 \\
60 \\
90 \\
80 \\
80 \\
80\end{array}$ & $\begin{array}{r}6.120 \\
86.151 \\
5.583 \\
7.524 \\
2.377 \\
19.186 \\
17.451 \\
12.331 \\
2.295 \\
4.886 \\
3.584 \\
4.788\end{array}$ & $\begin{array}{r}9 \\
129 \\
8 \\
11 \\
3 \\
29 \\
26 \\
19 \\
3 \\
7 \\
5 \\
7\end{array}$ \\
\hline 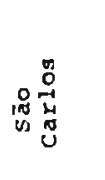 & $\begin{array}{l}\text { Descalvado } \\
\text { Dourado } \\
\text { Ibate } \\
\text { P.ibeirão unnito } \\
\text { São Carloz } \\
\text { Sta. Kita Basa Quatro }\end{array}$ & $\begin{array}{r}16.960 \\
5.071 \\
7.455 \\
6.355 \\
94.585 \\
18.114\end{array}$ & $\begin{array}{l}80 \\
20 \\
20 \\
15 \\
20 \\
80\end{array}$ & $\begin{array}{r}3.568 \\
1.014 \\
1.491 \\
953 \\
10.917 \\
14.515\end{array}$ & $\begin{array}{r}5 \\
1 \\
2 \\
1 \\
26 \\
22\end{array}$ \\
\hline & $T O I A L$ & 1.459 .670 & 59,90 & 874.284 & 1295 \\
\hline
\end{tabular}

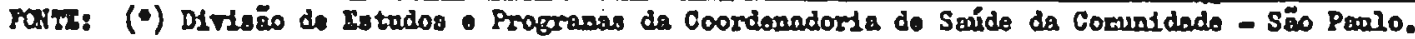
(*) DLfräo Reglonal do Sańdo de Ribolräo Proto - DRS 6. 
b) vias de comunicação existentes;

c) distāncia entre os vários municípios;

d) municīpio de procedēncia do doente, segundo dados notificados pela DRS- 6 nos anos de $1969,70,71$;

e) localização dos laboratōrios, preferente mente nos municipios-sede de distrito sanitārio.

O nūmero de baciloscopias que deve rā ser realizado foi calculado estimandose 12 baciloscopias para cada caso descoberto, levando-se em conta que no municipio de Ribeirão Preto ${ }^{4}$ foi encontrada uma taxa de positividade de $8 \%$ entre os sintomáticos respiratórios; quer dizer que, para se encontrar um caso, seria necessário realizar aproximadamente 12 baciloscopias.

1) Para o controle do tratamento, BERNAL 50 recomenda que se realize uma baciloscopia mensal, durante os seis primeiros me ses, e l baciloscopia trimestral, nos seis meses subsequentes.

2) 0 nūmero de baciloscopias anual foi esti pulado atravēs de uma jornada de traba1 ho de 4 horas diārias, durante 200 dias, realizando cada Laboratōrio um nūmero mê dio de 10 baciloscopias diārias.

Os Laboratōrios Locais e os Postos de Colheita de Amostras (PCA) foram todos 
organizados e distribuidos por sub-região, obedecendo aos critērios anteriormente men cionados.

A Rede de Laboratório estipulada para a Divisão Regional de Saūde de Ribeirão Preto (DRS-6) constarā em nümeros globais de 80 unidades, assim distribuidas:

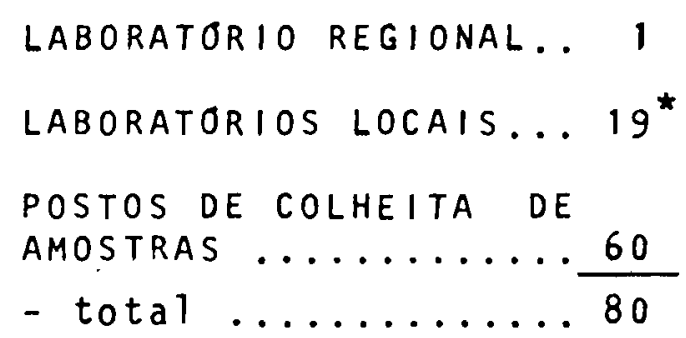

A legenda representando as diversas Unidades componentes da Rede serā apre sentada de acordo com os seguintes símbolos:
a) LABORATORIO REGIONAL
b) LABORATORIO LOCAL (a serem criados).
c) LABORATORIO EXISTENTE
d) POSTOS DE COLHEITA DE AMOSTRAS (PCA)

Obedecendo as delimitaçōes das diversas sub-regiões, as unidades integrantes da Rede de Laboratórios realizarāo o nümero de baciloscopias especificado nas diversas tabelas correspondentes a cada região e es*DOS LABORATORIOS LOCAIS, 3 deles jä estão
criados. 
tarão assim distribuĩdas:

a) SUB-REGIAO $I: 1$ - DISTRITO SANITARIO DE RI BEIRAO PRETO

Possuindo 12 municípios, tem como sede de distrito o municīpio de Ribeirão Preto, que tambēm ē a sede da Divisão Regional de Saūde nọ 6 (DRS-6). Estā previs to para esta sub-região o Laboratório Regional, 2 Laboratōrios Locais (Sertãozinho e São Simão) e 9 Postos de Có Theita de Amostras (PCA). A FIGURA n: 7 mostra o mapa da sub-região, assim como as diversas unidades. A TABELA n? 9 estabelece o número de baciloscopia a ser executado pelos respectivos Laboratórios.

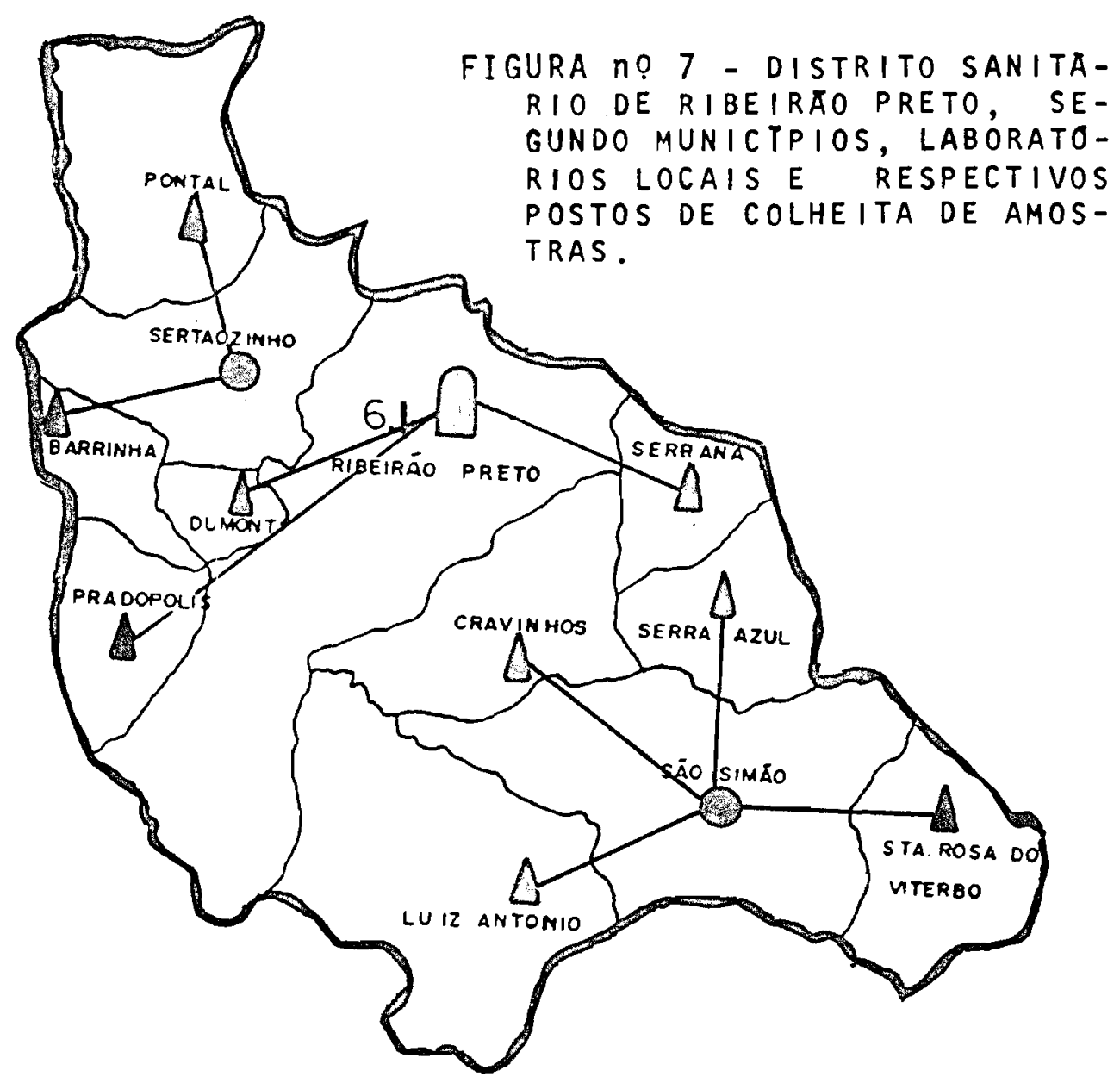


TABELA ne 9 - NEMERO DE BACILOSCOPIAS A SER REALIZADO PELOS LABORATÓI:IOS UE RIBEIRÃO PRETO, SERTÃOZINHO O SÃO SI MÃO, EM FUNÇÃG DO NUMERO ESTIMADO DE CASOS DE TUBER= CULOSE - 1975




b) SUB-REGIAO $I: 2$ - DISTRITO SANITARIO DE BATATAIS

Contendo 7 municipios, tendo como sede de Distrito o municipio de Batatais, 2 Laboratōrios Locais situados nas cidades de Batatais e Altinōpolis serão os responsãveis pelos exames bacteriológicos. Os Postos de Colheita de Amostras desta sub-região serão em nūmero de cinco (5). A flgura no 8 apresenta o mapa da sub-região.

FIGURA NO 8 - DISTRITO SANITARIO DE BATATAIS, SEGUNDO MUNICIPIOS, LABORATORIOS LOCAIS E RESPECTIVOS POSTOS DE COLHEITA DE AMOSTRAS.

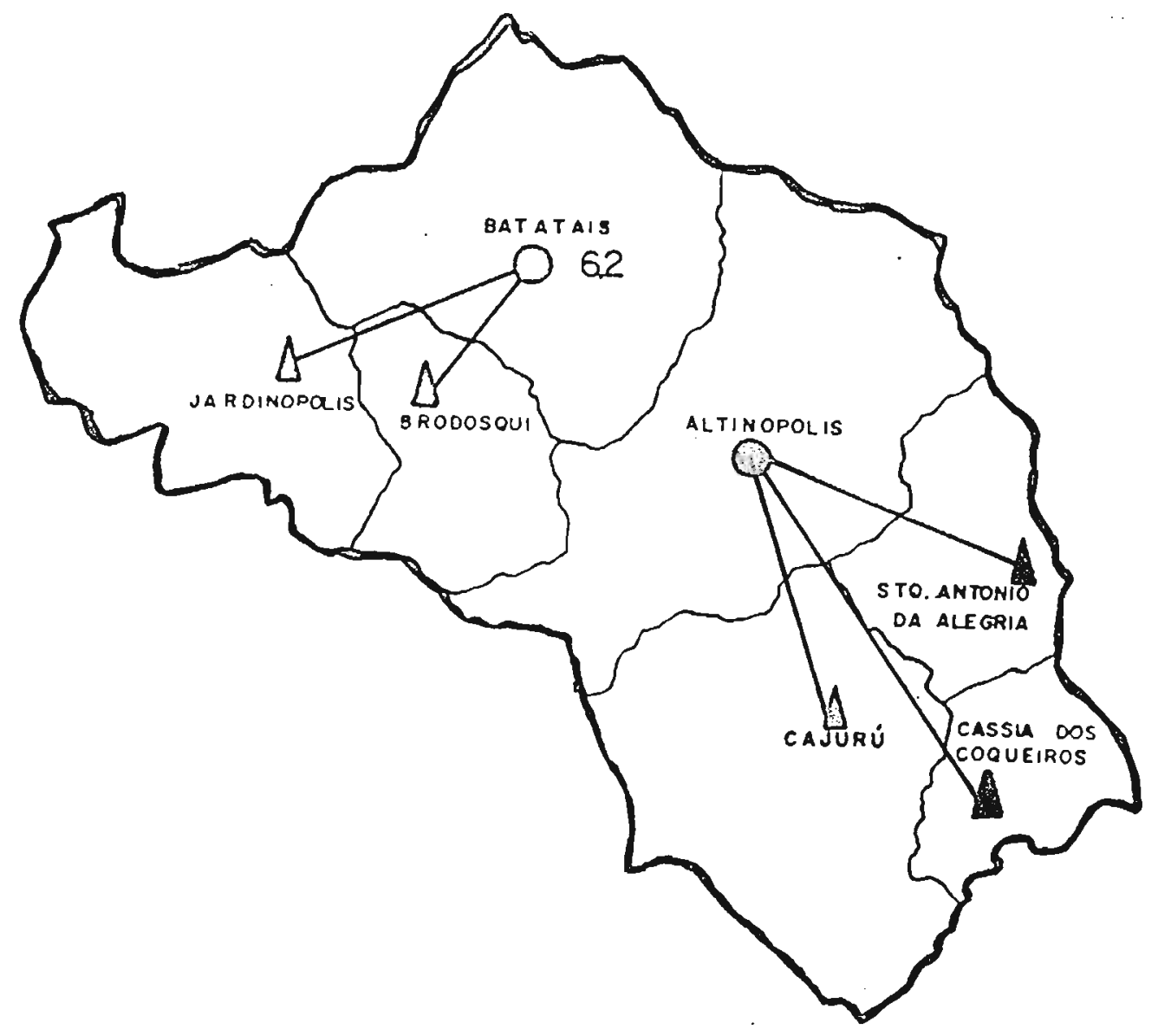


o número de bacjioscopias a ser efetuado bem como os Laboratōrios Locais, são citados na TABELA n? 10.

TABELA nO 10 - NUMRRO DE BACILOSCOPIA A SER REALIZADO PELOS LABORATÓRIOS LOCAIS DE BATATAIS E ALTINOPOLIS, EM FUNÇAO DO NGMERO ESTIMADO DE CASOS DE TUBERCULO $S E-1975$

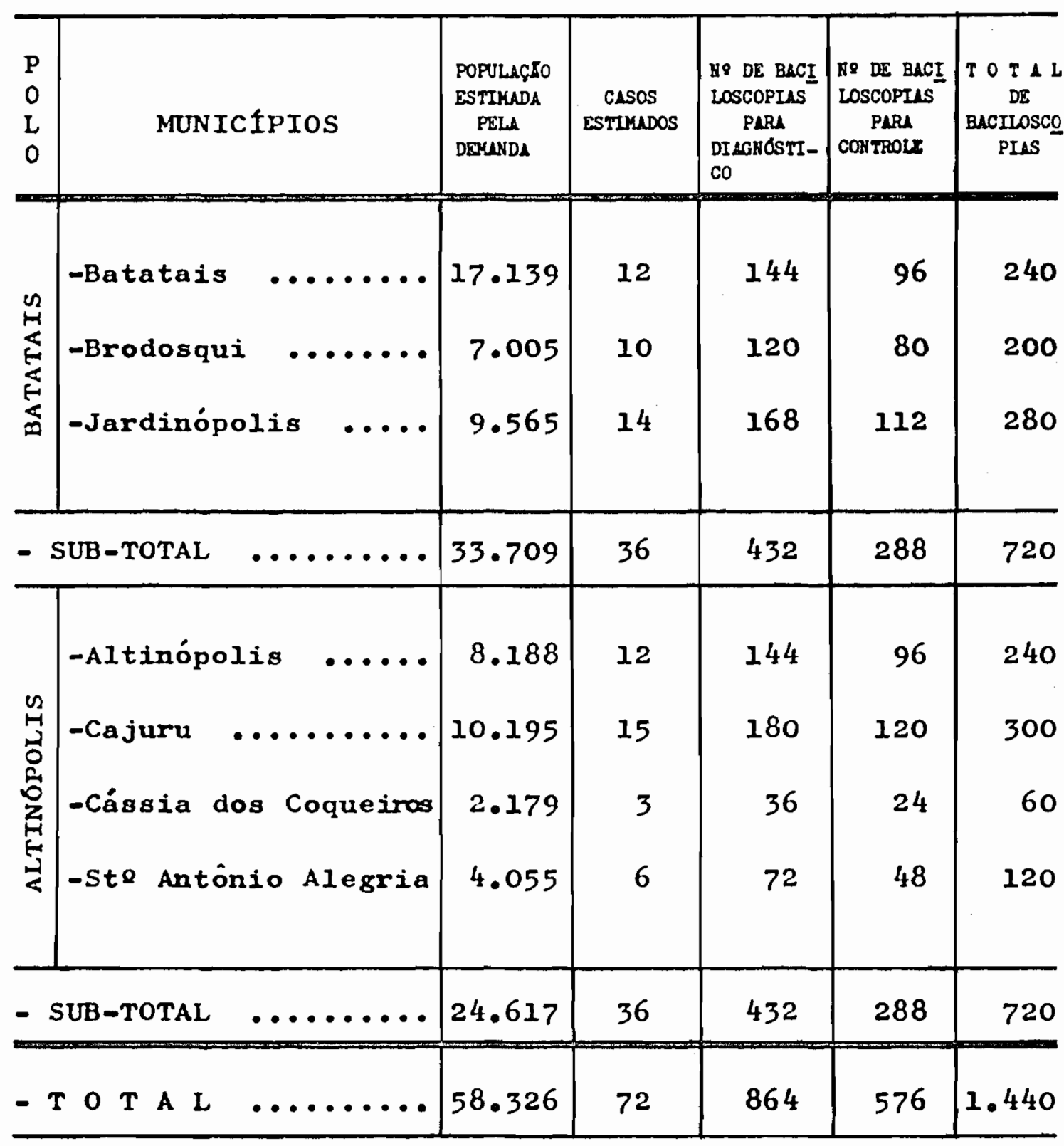


c) SUB-REGIAOO N:3 - OISTRITO SANITARIO DE FRAN -

Esta sub-região possui 9 municípios, sendo a sede de Distrito o município de Franca. Dois (2) Labora tōrios Locais farão a rotina diagnōstica, localizados na cidade de Franca e Pedrequiho.

- Laboratório Local de Franca jā existe e perten ce ao Instituto Adolfo Lutz. Sete (7) Postos de Colheita de Amostras (PCA) estão previstos para esta sub-região.

A firuRA no 9 exibe o mapa da sub-região. A TA BELA n? 11 especifica o nūmero de exames a serem feitos pelos Laboratōrios Locais.

FIGURA NO 9 - DISTRITO SANITKRIO DE FRANCA, SEGUNDO MUNICI DIOS, LABORATCRIOS LOCAIS E RESPECTIVOS POSTOS DE C $\overline{0}$ LHEITA DE AMOSTRAS.

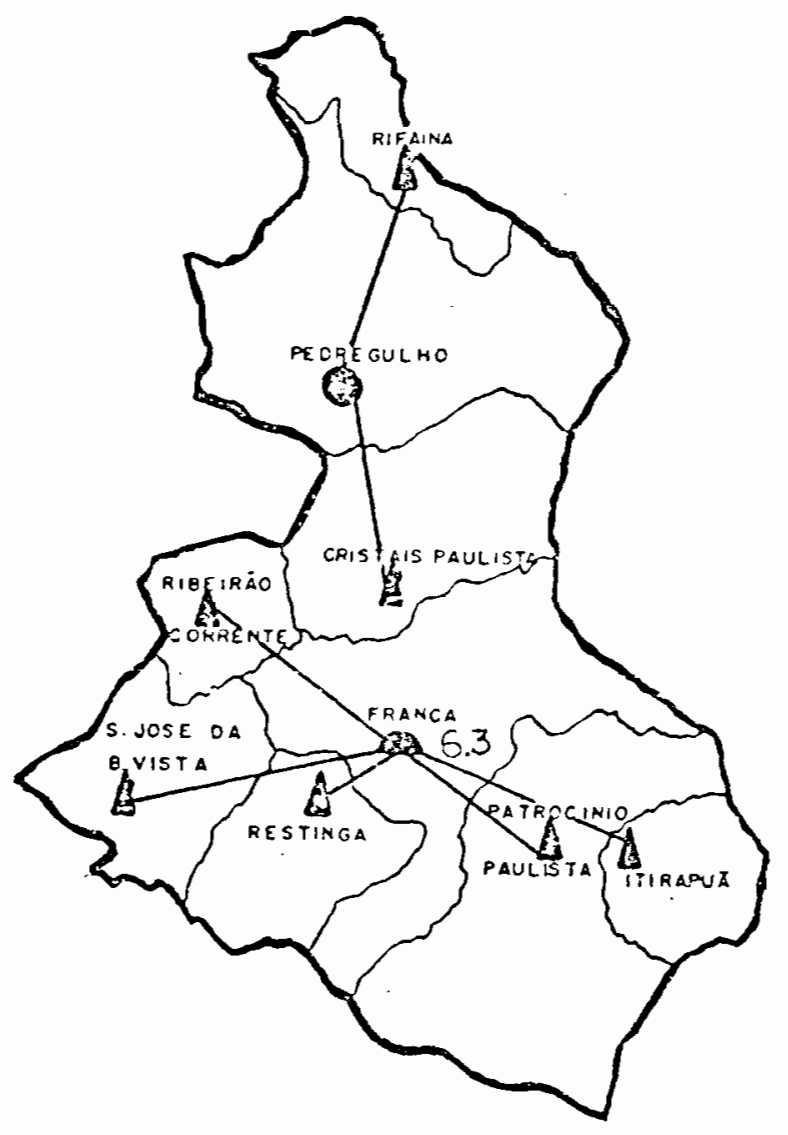


TABELA ne 11 - NOMERO DE BACILOSCOPIAS A SER REALIZADO PE LOS LABORATORIOS DE FRANCA E PEDREGULHO, EM FUNÇ $\overline{\bar{O}}$ DO NÓMERO ESTIMADO DE CASOS DE TUBERCULOSE - 1975

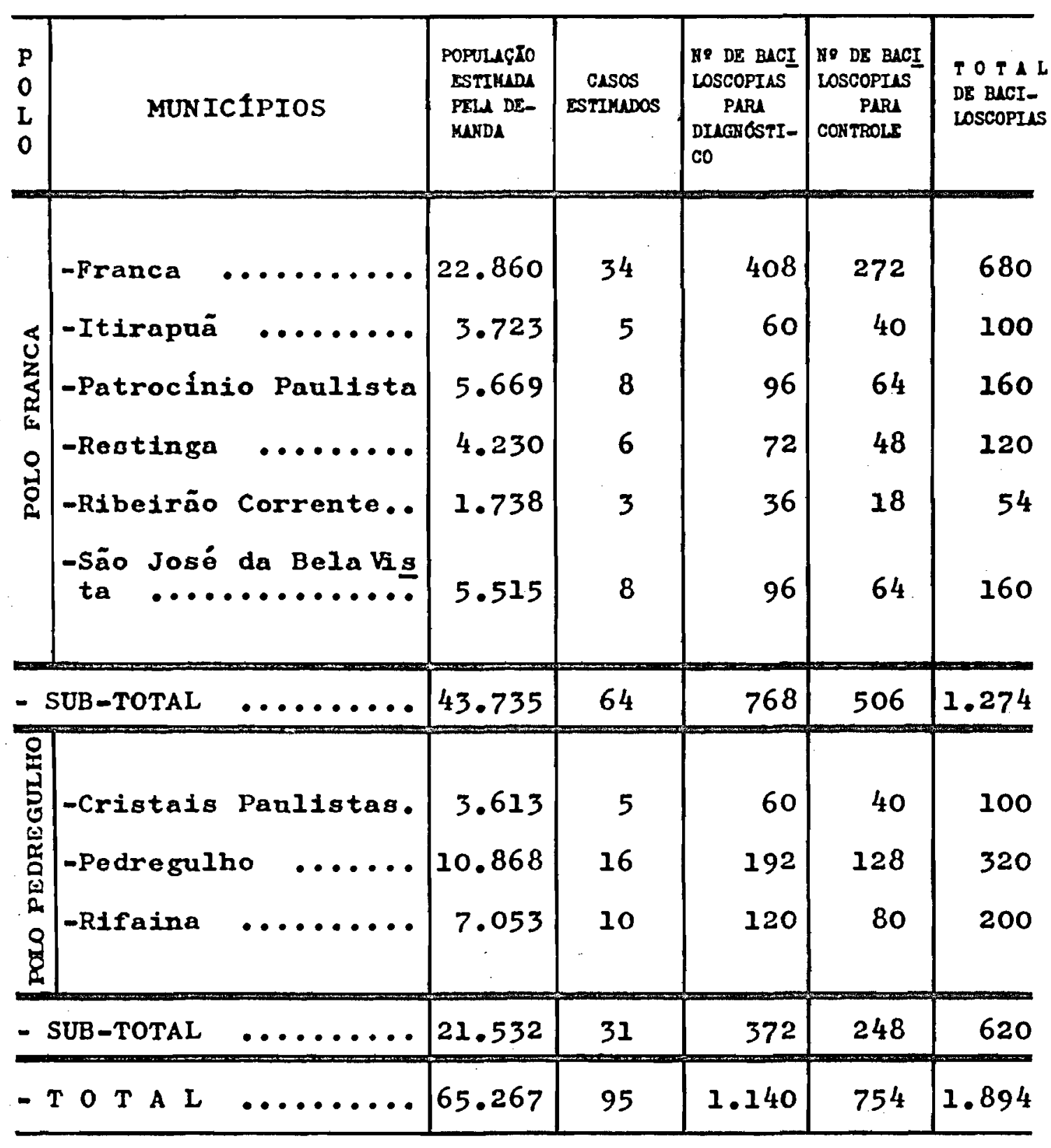


d) SUB-REGIAO NO 4 - DISTRITO SANITARIO DE ITUVERAVA

Sete (7) municioios fazem parte desta subregião, tendo Ituverava como sede de Distrito. Para esta sub-região 2 Laboratōrios Locais serão os responsāveis pe la rotina bacteriológica, localizados respectivamente em Ituverava e Igarapava. Cinco (5) Postos de Colheita de Amostras (PCA) estão previstos para esta sub-região. A FIGURA n: 10 mostra o mapa da sub-região. Na TABELA n! 12 são quantificadas as baciloscopias a serem realizadas pelos Laboratörios.

FISURA $n ? 10$ - DISTRITO SANITARIO DE ITUVERAVA, SEGUNDO MU NICIPIOS, LABORATORIOS LOCAIS E RESPECTIVOS POSTOS OE COLHEITA DE AMOSTRAS.

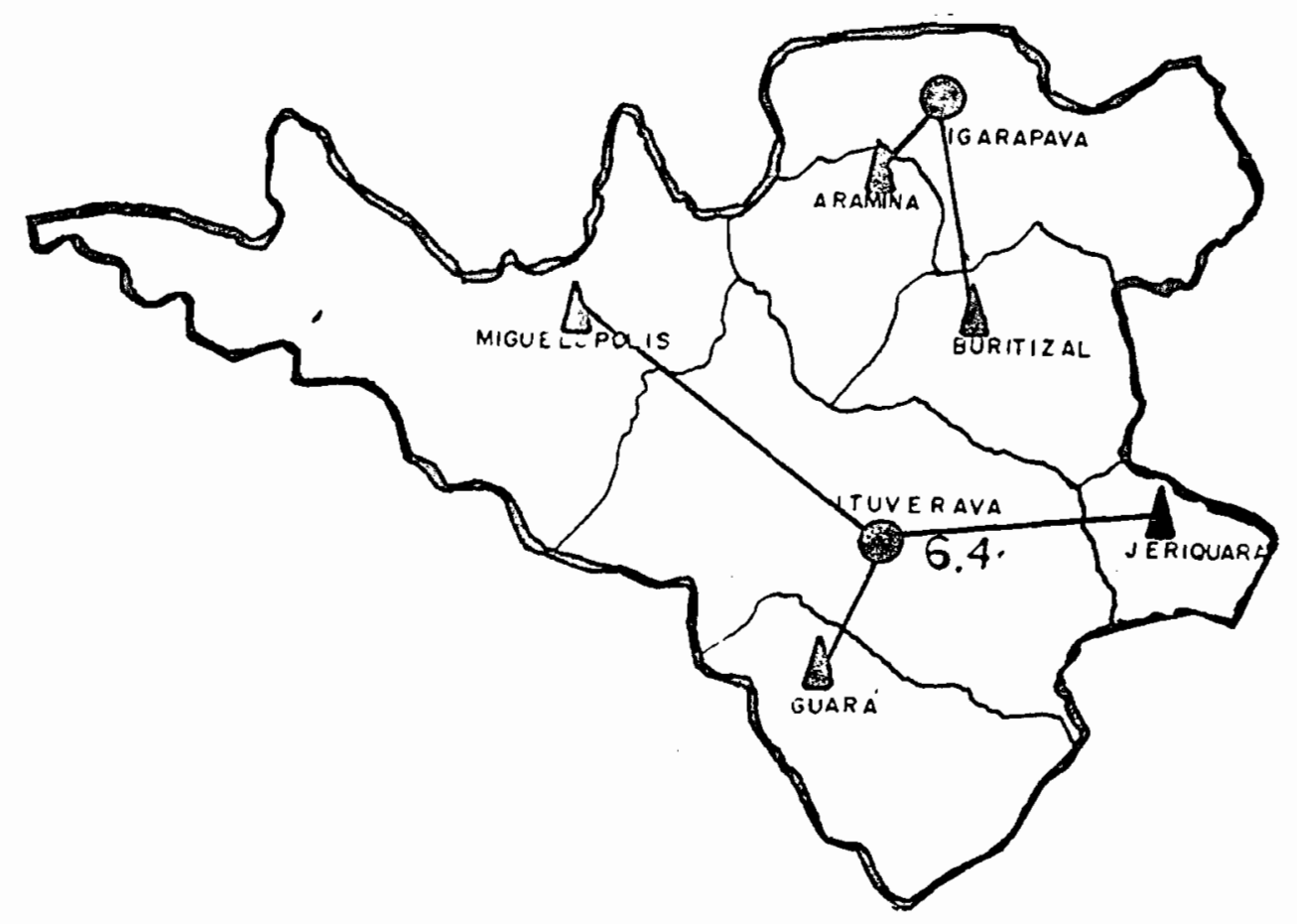


TABELA ne 12 - NOMERO DE BACILOSCOPIAS A SER REALIZADO PELOS LABORATÓRIOS LOCAIS DE ITUVERAVA E IGARAPAVA EM FUNÇAO DO NUMERO ESTIMADO DE CASOS DE TUBERCULOSE 1975

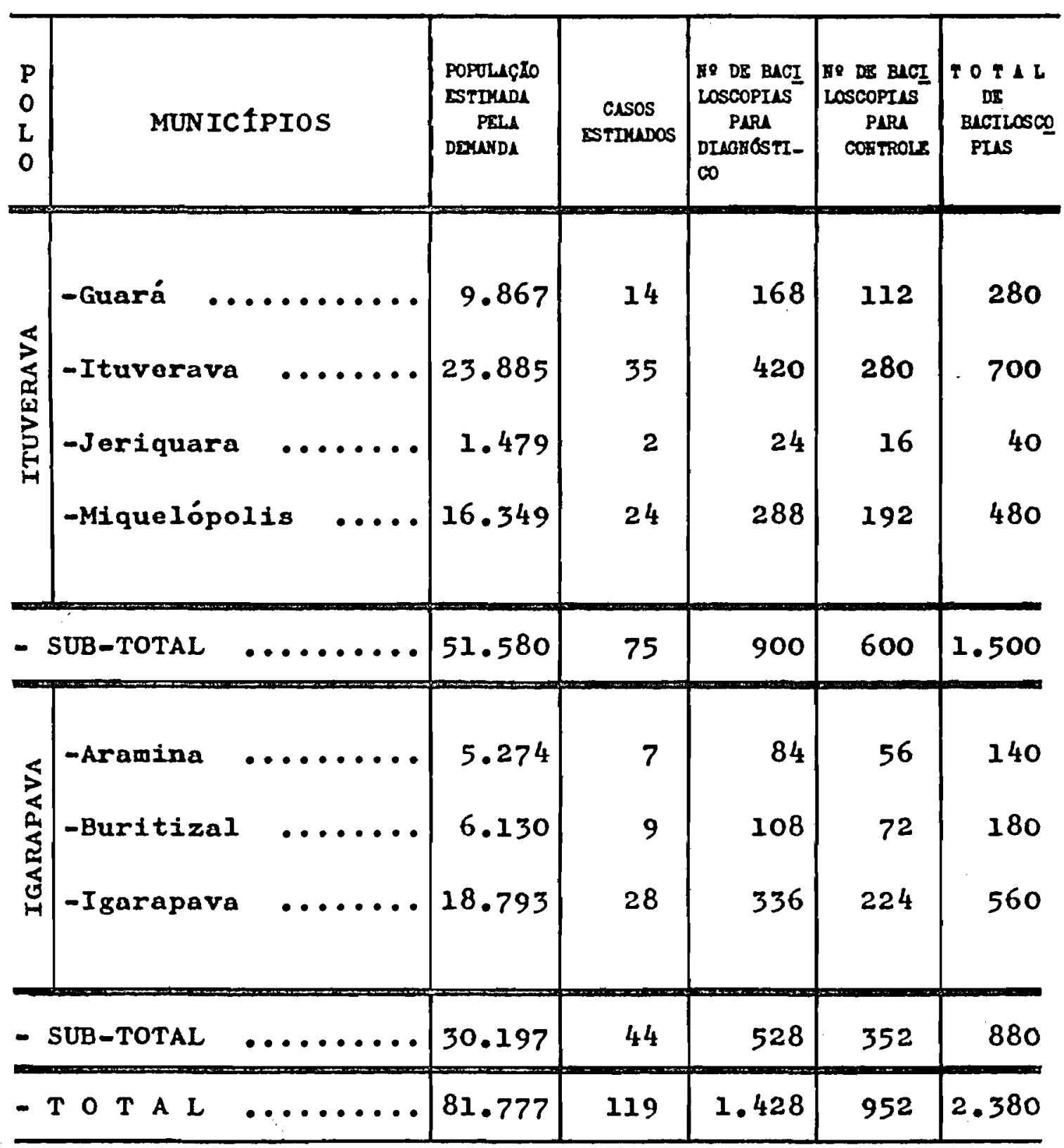




\section{e) SUB-REGIAO n? 5 - DISTRITO SANITARIO DE SAO JOAQUIM DA BARRA}

Possui esta sub-região 6 municípios, tendo como sede de Distrito São Joaquim da Barra. Dois (2) Labo ratōrios Locais estão previstos para esta sub-região, loca lizados nos municípios de São Joaquim da Barra e orlândia. Quatro (4) Postos de Colheita de Amostras (PCA) foram esta belecidos para a colheita de material. A flgURA no 11 exi be o mapa da sub-região. A TABELA no 13 mostra o total de baciloscopias que deverá ser realizado pelos respectivos Laboratōrios Locais.

\section{FIGURA $I$ P 11 - DISTRITO SANITARIO DE SAO JOAOUIM DA BARRA, SEGUNDO MUNICTPIOS, LABORATORIOS LOCAIS E RESPECTI- VOS POSTOS DE COLHEITA DE AMOSTRAS.}

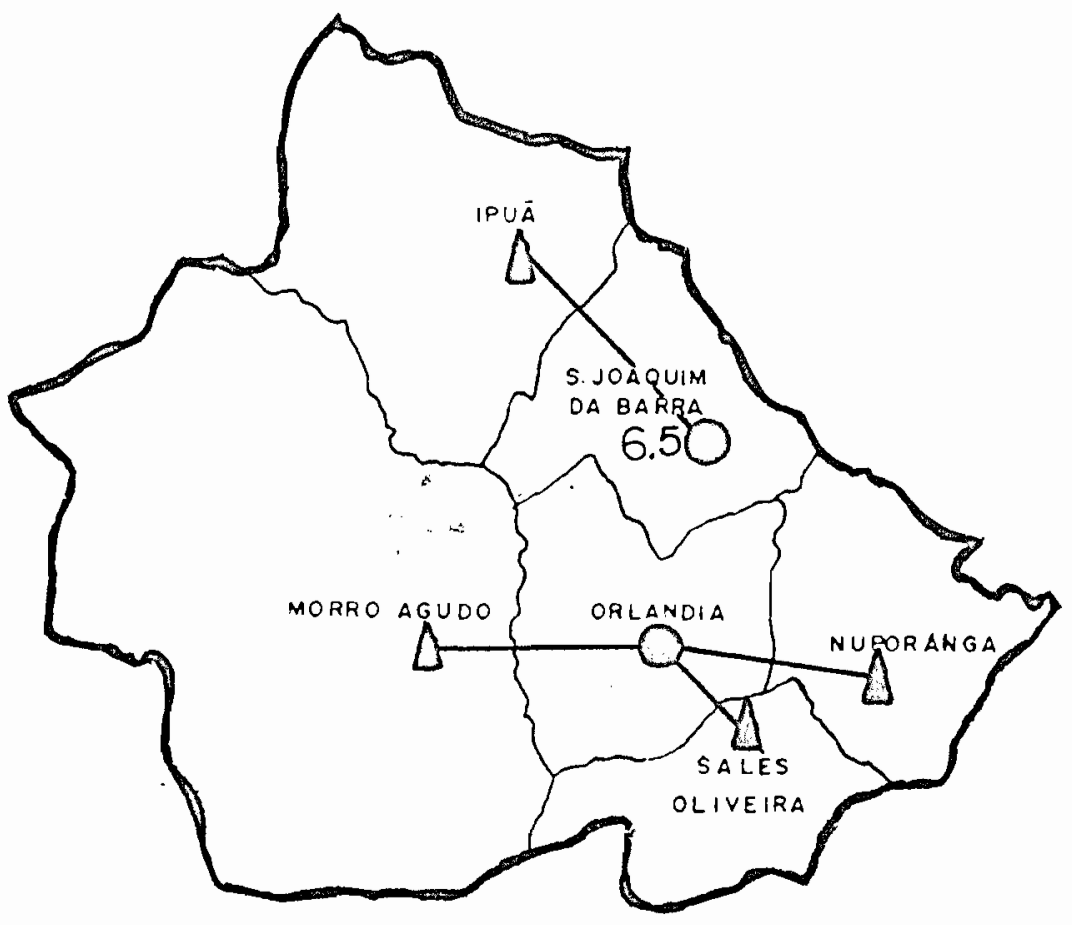


TABELA nQ 13 - NOMERO DE BACILOSCOPIAS A SER REALIZADO PELOS LABORATORIOS LOCAIS DE SÃO JOAQUIM DA BARRA E ORLANDIA, EM FUNÇÃO DO NGMERO ESTIMADO DE CASOS DE TUBERCULOSE - 1975

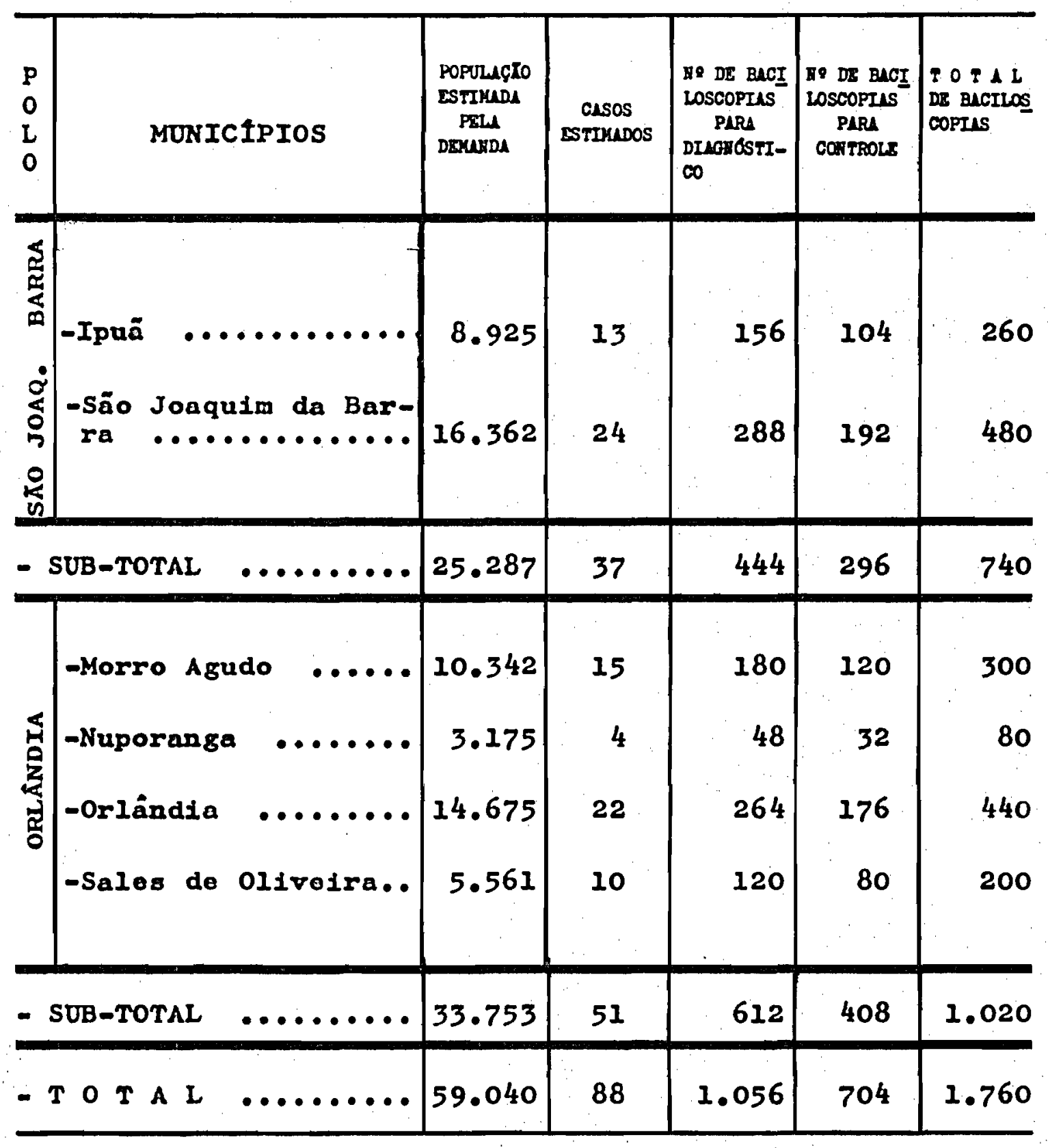


f) SUB-REGIAO ח? 6 - DISTRITO SANITARIO DE BAR RETOS

Conta esta sub-região com 5 municipios, ten do como sede de Distrito o municipio de Barretos. Apenas um (1) Laboratōrio Local estā previsto para esta sub-regi ão e estará localizado no município de Barretos. Cinco (5) Postos de Colheita de Amostras (PCA) foram estipulados para esta sub-região. A fIGURA no 12 mostra o mapa da sub-regiāo. Podemos observar na TABELA n? 14 o número de baciloscopias que deverá ser realizado pelo Laboratório Lo cal.

FIGURA NO 12 - DISTRITO SANITARIO DE BARRETOS, SEGUNDO MUNICTPIOS, LABORATORIOS LOCAIS E RESPECTIVOS POSTOS DE COLHEITA DE AMOSTRAS - 1975.




TABELA nO 14 - NUMERO DE BACILOSCOPIAS A SER EPETUADO PELO LABORATORIO LOCAL DE BARRETOS, EM FUNÇÄO DO NOMERO EST TMAADO DE CASOS DE TUBERCULOSE - 1975

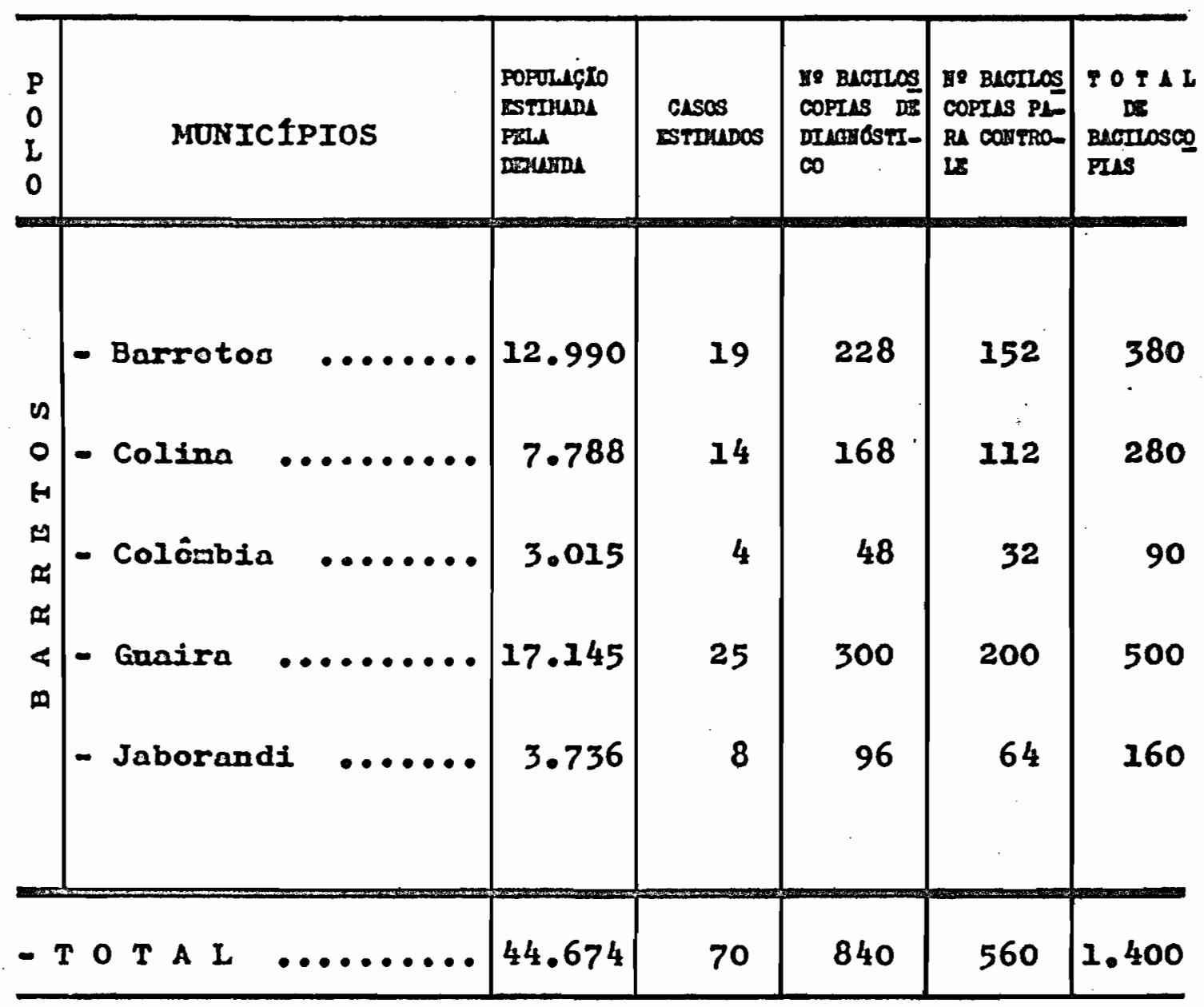


g) SUB-REGIAO ח旦 7 - UISTRITO SANITARIO DE JABOT ICABAL

Possui esta sub-região oito (8) municípios, sendo o municipio de Jaboticabal a sede de Distrito da sub região. Dois (2) Laboratōrios Locais estão previstos para este Distrito, que deverão estar localizados nos municĩpios de Jaboticabal e Taquaritinga. Seis (6) Postos de Co Theita de Amostras (PCA) foram estimados para esta sub-região. A flgura no 13 mostra o mapa da sub-região. Na tABELA n: 15 podemos observar o nümero de baciloscopias que deverá ser realizado pelos Laboratórios Locais.

FIGURA 13 - DISTRITO SANITARIO DE JABOTICABAL, SEGUNDO MU NICTPIOS, LABORATORIOS LOCAIS E RESPECTIVOS POSTOS DE AMOSTRAS.

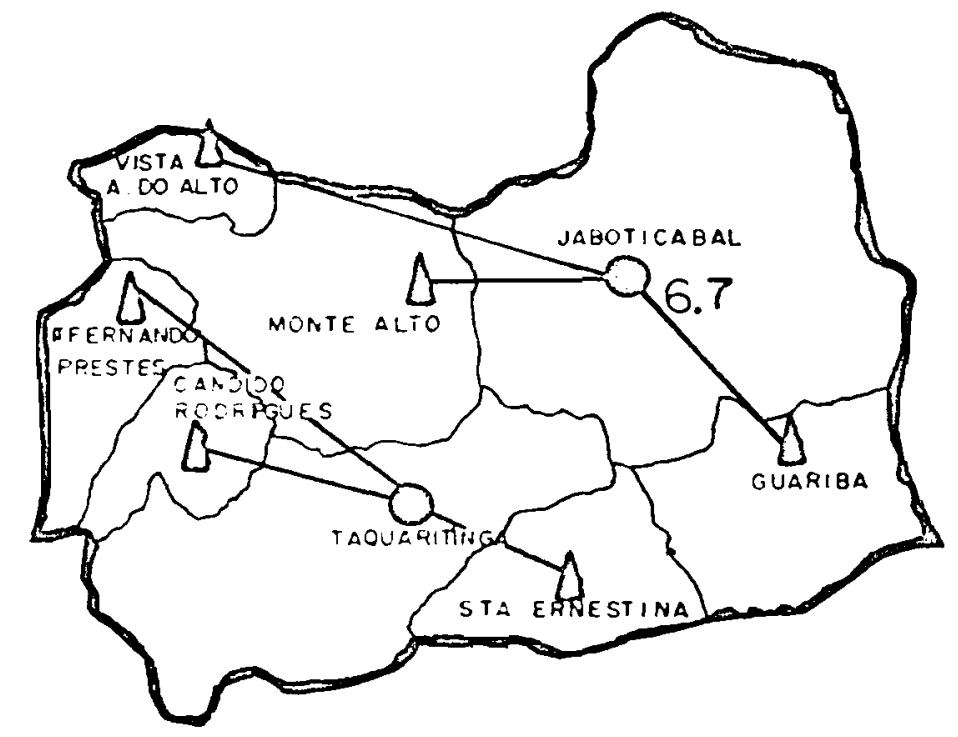


TABELA nR 15 - NOHERO DE BACILOSCOPIAS A SER EPETUADO PELOS LABORATORIOS LOCAIS DE JABOTICABAL E TAQUARI TINGA, BM PUNÇAOO DO NURERO ESTIMADO DE CASOS DE TQ BERCULOSE - 1975

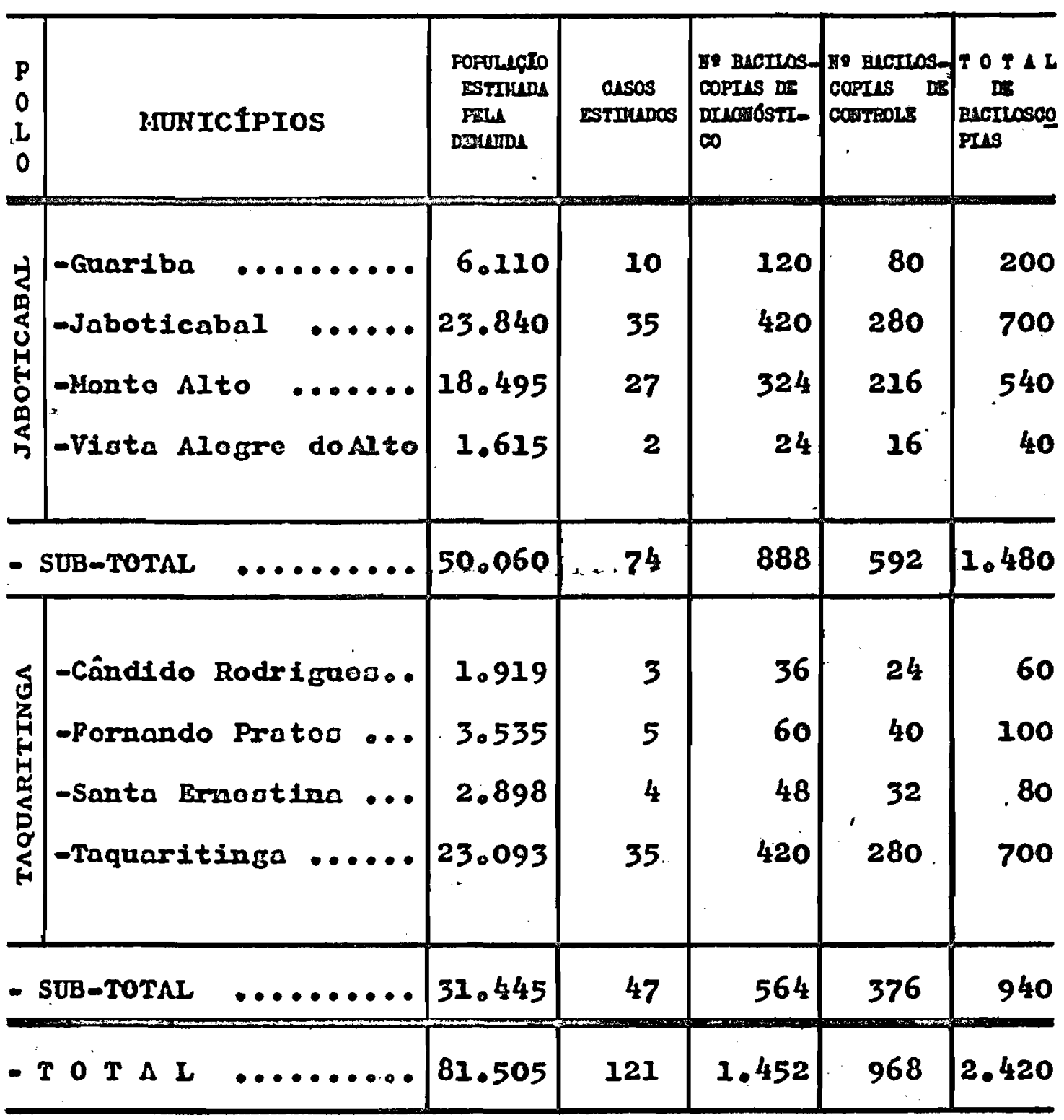




\section{h) SUB-REGIAO ח? 8 - DISTRITO SANITARIO DE BE-}

\section{BEDOURO}

0ito (8) municipios fazem parte desta sub-re gião, sendo o município de Bebedouro a sede de Distrito. Apenas um (1) Laboratōrio Local fará a rotina bacteriológ ca. Foram estipulados para esta sub-região sete (7) Postos de Colheita de Amostras (PCA). A FIGURA n? 14 mostra - mapa representativo da sub-região. Na TABELA n? 16 pode remos verificar o nümero de baciloscopias que deverá ser executado pelo Laboratōrio Local.

FIGURA 14 - DISTRITO SANITARIO DE BEBEDOURO, SEGUNDO MUNICIPIOS, LABORATORIOS LOCAIS E RESPECTIVOS POSTOS DE COLHEITA DE AMOSTRAS.

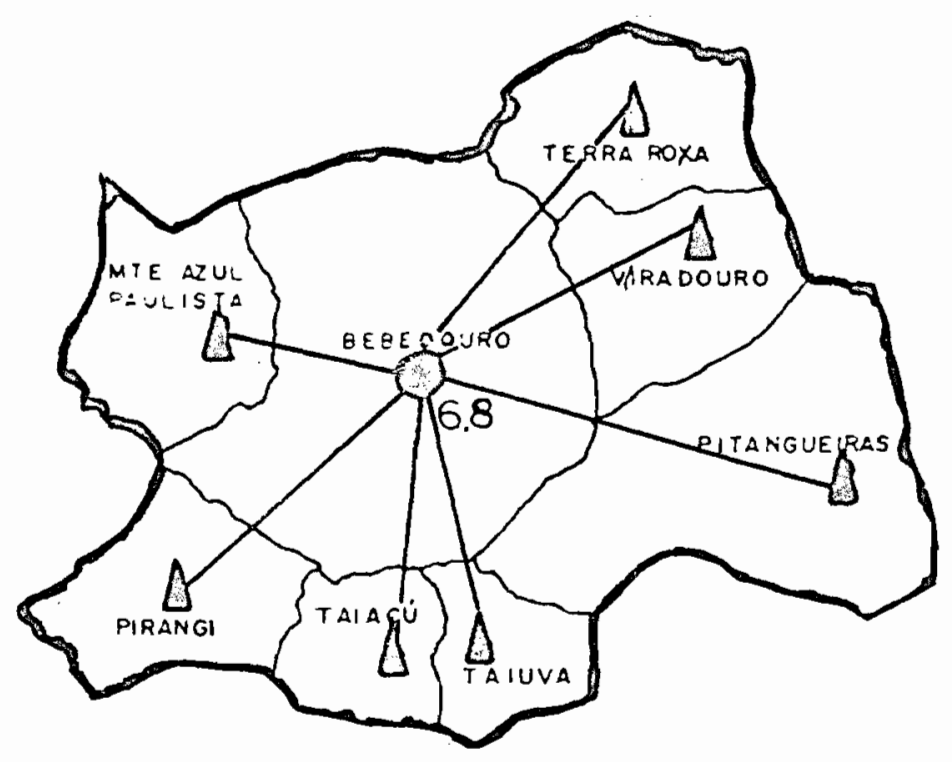


TABELA nQ 16 - NTMERO DE BACILOSCOPIAS A SER EFETUADO PELO LABORATORIO LOCAL DE BEBEDOURO, EM FUNÇĀO DO NU MERO ESTIMADO DE CASOS DE TUBERCULOSE - 1975

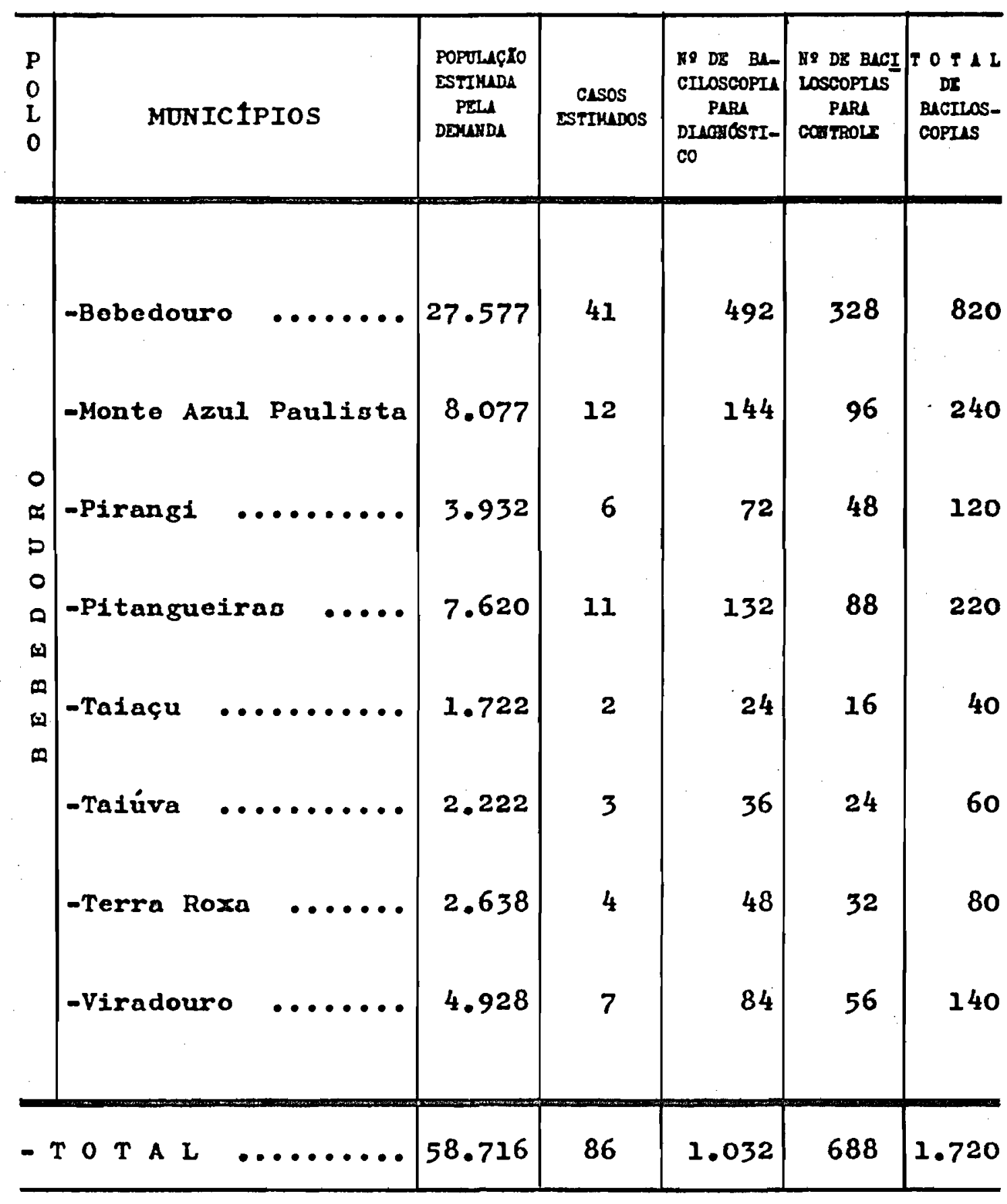


i) SUB-REGIAO NO9-DISTRITO SANITARIO DE ARA RAQUARA

Contēm esta sub-reạião 11 municīpios, sendo o de Araraquara a sede do Distrito. Dos trēs (3) Laborató rios Locais orevistos, um (1) jā está criado e funciona no Serviço Especial de Saūde (SESA), situado no municíoio de Araraquara. Os dois outros Laboratōrios Locais estarão localizados respectivamente nos municipios de lbitina e Itānolis. Nove (9) Postos de Colheita de Amostras (PCA) foram estimados nara esta sub-reniān. A flgurA no 15 expõe 0 mapa da sub-região. Na TABELA n? 17 é apresentado o número de baciloscopias que deverá ser realizado pelos diversos Laboratōrios Locais.

FIGURA TO 15 - DISTRITO SANITARIO DE ARARAOUARA, SEGUNDO MUNICTPIOS, LABORATORIOS LCCAIS E RESPECTIVOS POSTOS DE COLHEITA DE AMOSTRAS.

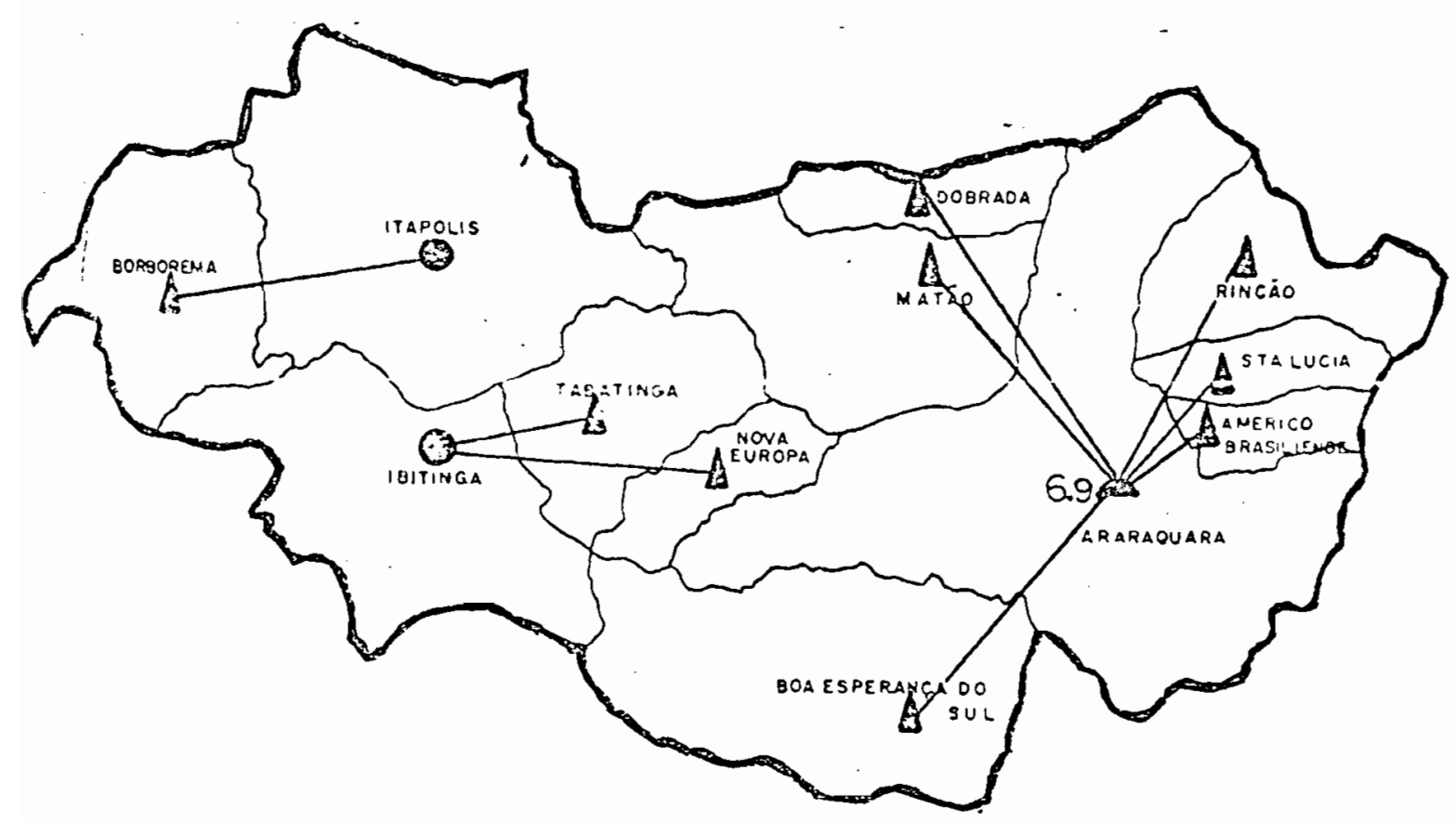


TABELA n० 17 - HÓTERO DE BACILOSCOPIAS A SER EPETUADO PELOS LABORATORIOS LOCAIS DE ARARAQUARA, IBITINGA E ITÁPO LIS, EM PUNCÃO DO IUTERO ESTIMADO DE CASOS do TUBERCULO $S E-1975$

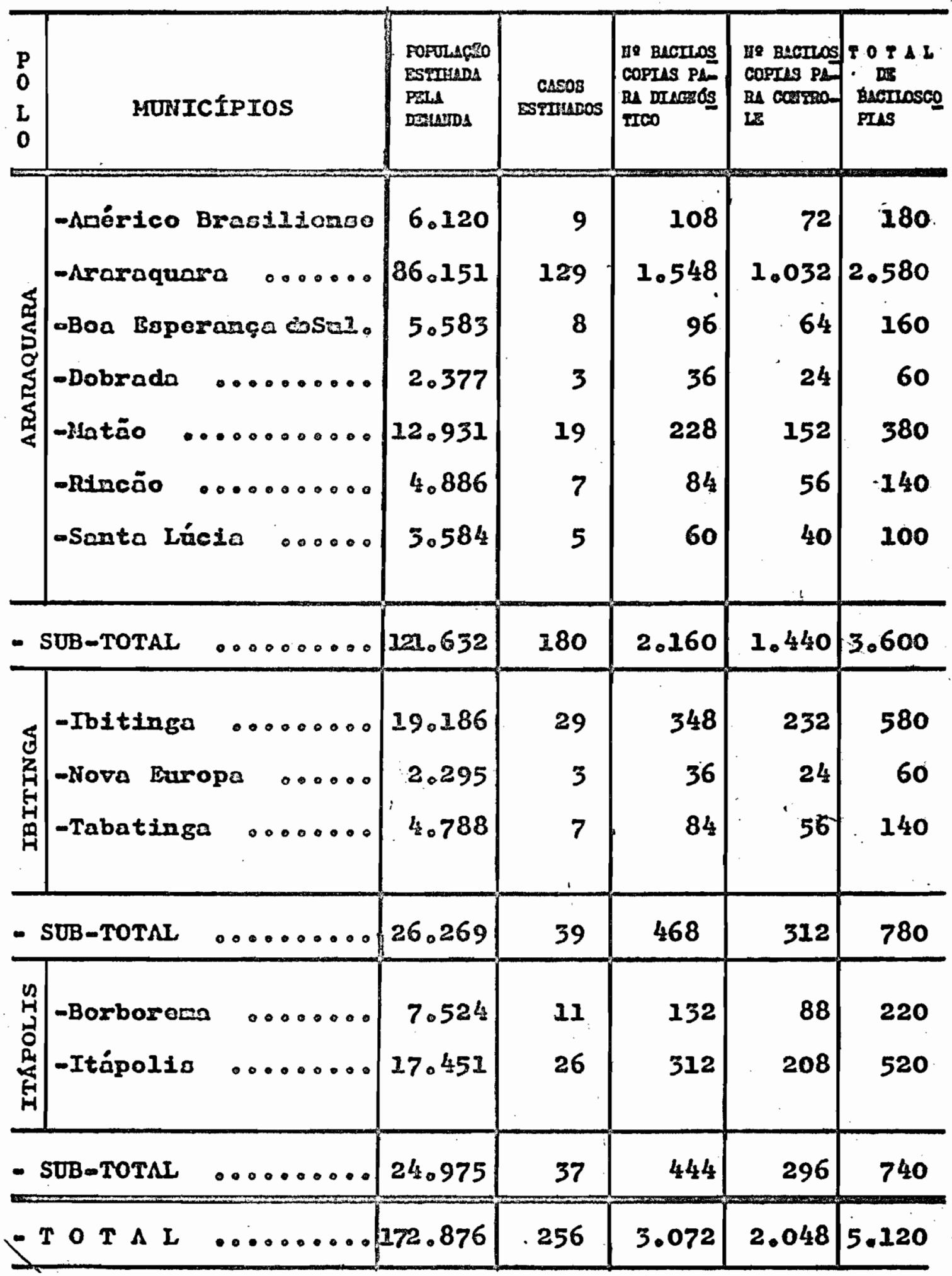




\section{j) SUB-REGIAO N?10-DISTRITO SANITARIO DE SAO CARLOS}

Contēm esta sub-região seis (6) municīpios, tendo o municipio de São Carlos como sede de Distrito. 2 Laboratōrios Locais foram calculados para esta sub-região, localizados nos municípios de São Carlos e Santa Rita do Passa Quatro. Ho entanto, o Laboratōrio Local de São Carlos jā existe e pertence ao Instituto Adolfo Lutz; portan to, haveria necessidade de se criar apenas um (1) Laborató rio no municipio de Santa Rita do Passa Quatro. Quatro (4) Postos de Colheita de Amostras (PCA) deverão fazer a coTheita do material. A flgura no 16 apresenta o mapa da sub regiāo, enquanto a TABELA n: 18 mostra o nūmero de baciloscopias que deverā ser realizado pelos respectivos Laboratōrios.

FIRURA NO 16 - DISTRITO SANITARIO DE SAO CARLOS, SEGUNDO MUNICTPIOS, LABORATORIOS LOCAIS E RESPECTIVOS POSTOS DE COLHEITA DE AMOSTRAS.

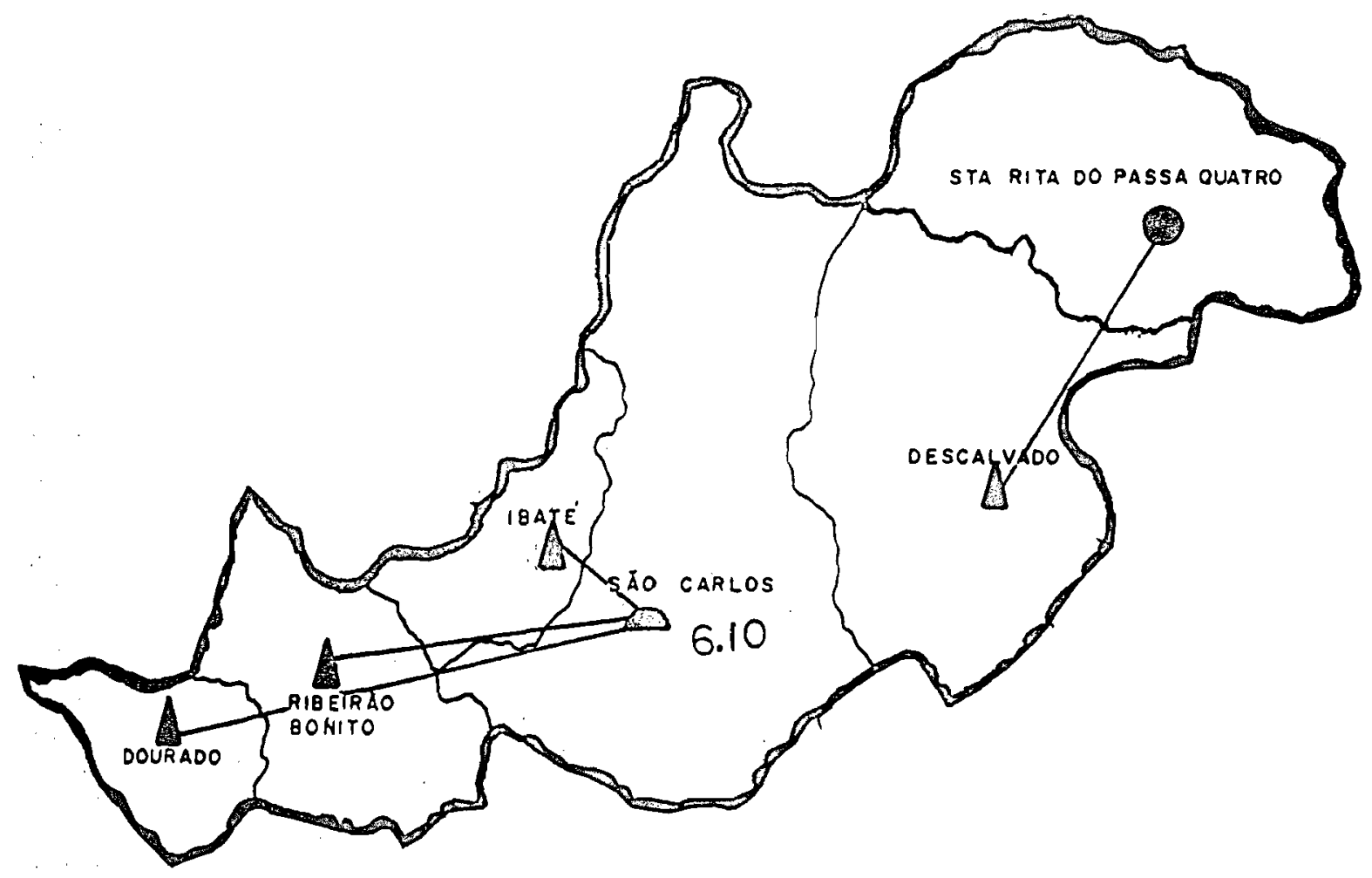


TABELA nQ 18 - NUMERO DE BACILOSCOPIAS A SER EFETUADO PELOS LABORATÓRIOS LOCAIS DE SÃO CARLOS E SANTA RITA DO PASSA QUATRO, EM FUNÇĂO DO NUMERO ESTIMADO DE CASOS DE TUBERCULOSE - 1975

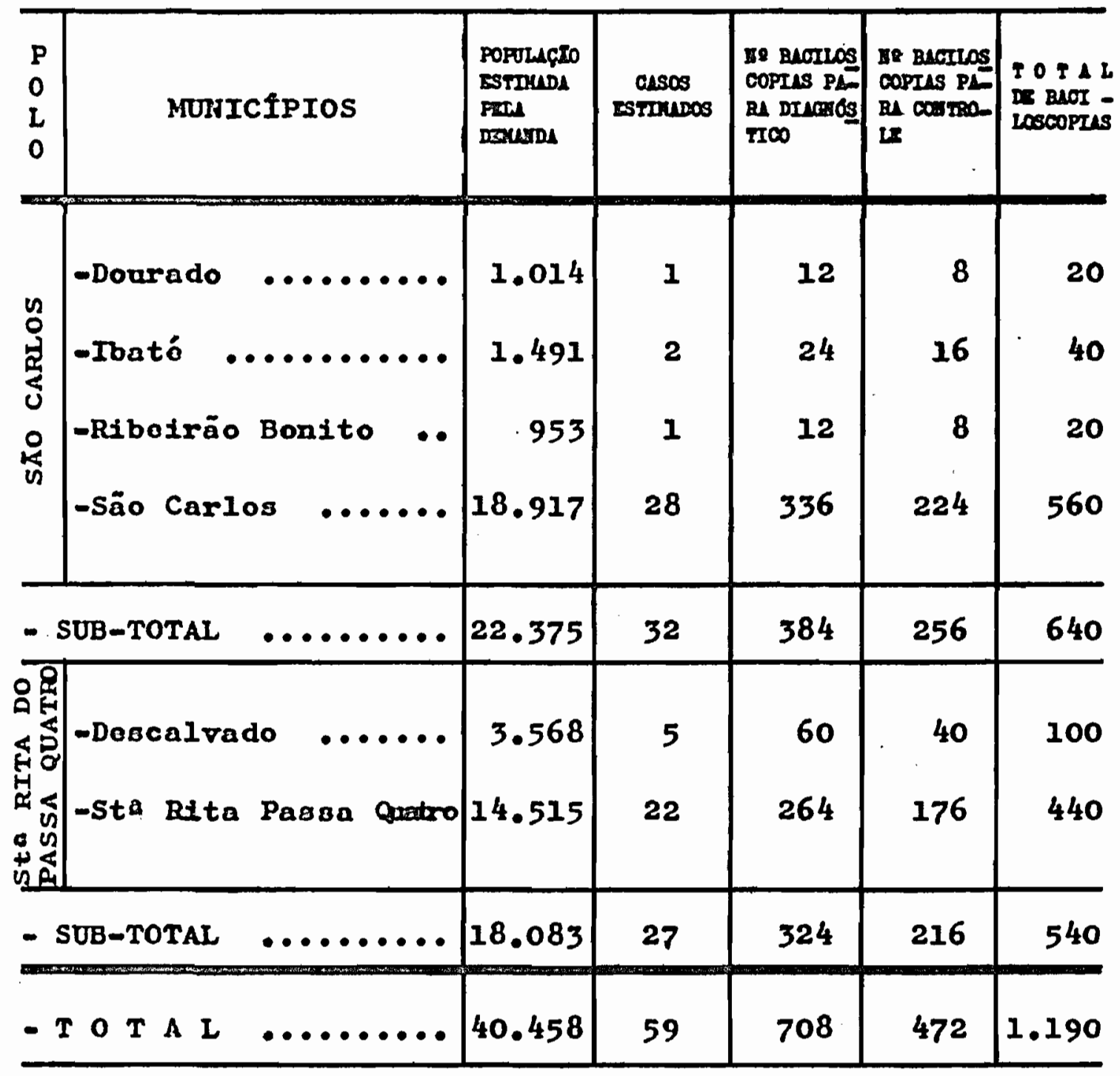


Finalmente, complementando os cālculos, a TABELA n? 19 estabelece a população estimada para cada polo, o nú mero de casos e o total de baciloscopias para diagnōstico e tratamento, que deverā ser efetuado pelos diversos serviços polo.

Na FIGURA n: 17 apresentamos uma distribuição completa da Rede de Laboratōrios de Bacteriologia da Tuber culose e as suas respectivas interligações, estipulada para a Divisão Regional de Saúde de Ribeirão Preto (DRS-6).

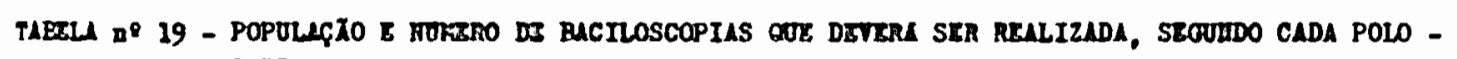
1975

\begin{tabular}{|c|c|c|c|c|c|}
\hline$P O L D$ & $\begin{array}{c}\text { POPUL AGRO } \\
\text { ESTIMLA }\end{array}$ & $\begin{array}{l}\text { C A S O S } \\
\text { Estmados }\end{array}$ & $\begin{array}{l}\text { BACILOSCOPIA } \\
\text { PARA } \\
\text { DIAGHOSTICO }\end{array}$ & $\begin{array}{c}\text { BACILOSCOPIA } \\
\text { PARA } \\
\text { CORTROLI }\end{array}$ & $\begin{array}{c}\text { TOT } A \mathrm{~L} \\
\text { DE } \\
\text { BACILOSCOPIA }\end{array}$ \\
\hline - Adboiräo Proto $\ldots . \ldots \ldots \ldots .$. & 141.548 & 212 & 2.544 & 1.696 & 4.240 \\
\hline - Sertäostnho ......... & 31.953 & 47 & 564 & 376 & 940 \\
\hline - São Sizä ... & 38.144 & 57 & 684 & 456 & 1.140 \\
\hline 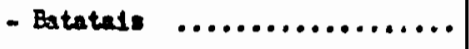 & 33.709 & 49 & 588 & 392 & 980 \\
\hline - Altinbpolls ... & 24.617 & 36 & 432 & 288 & 720 \\
\hline - Trasea....... & 43.735 & 64 & 768 & 512 & 1.280 \\
\hline - Pedrogalbo .... & 21.532 & 31 & 372 & 248 & 620 \\
\hline - Itorerara ..... & 51.580 & 75 & 900 & 6 & 1.500 \\
\hline - Igarapara ... & 30.197 & 44 & 528 & 352 & 880 \\
\hline - Säo Josquito da Burra $\ldots$ & 25.287 & 37 & 444 & 296 & 740 \\
\hline - Oriliedia ... & 33.753 & 51 & 612 & 408 & 1.020 \\
\hline - Barrotor $\ldots . . .$. & 44.674 & 70 & 840 & 560 & 1.400 \\
\hline - Jaboticabal ... & 50.060 & 74 & 888 & 592 & 1.480 \\
\hline - Isquaritinge ... & 31.445 & 47 & 564 & 376 & 940 \\
\hline - Bobodouro ..... & 58.716 & 86 & 1.032 & 688 & 1.720 \\
\hline - Araraquar .... & 121.632 & 180 & 2.160 & 1.440 & 3.600 \\
\hline - Ioltioga $\ldots .$. & 26.269 & 39 & 468 & 312 & 780 \\
\hline - Itápolis .... & 24.975 & 37 & 444 & 296 & 740 \\
\hline - São Carjos ..... & 22.375 & 32 & 384 & 256 & 640 \\
\hline - Sarte Rita do Passa oestro .. & 18.083 & 27 & 324 & 216 & 540 \\
\hline- TOTAL $\ldots$ & 874.284 & 1.295 & 35.540 & 10.360 & 25.900 \\
\hline
\end{tabular}


FIGURA NỌ 17 - DIVISAOO REGIONAL DE SADDE DE RIBEIRAO PRETO, SEGUNDO MUNICTPIOS, LABORATORIOS LOCAIS E RESPECTI VOS POSTOS OE COLHEITA DE AMOSTRAS, 1975.




Portanto, de acordo com os cálculos efetuados, para cobrirmos uma população de 874.284 habitantes $(59,90 \%$ da população geral) apenas com exame baciloscópico, deveremos efetuar 15.540 baciloscopias de diagnóstico e 10.360 baciloscopias de controle de tratamento, totalizando 25.900 baciloscopias diretas de escarro num tempo aproximado de um ano.

6.5.2.4.1. Atividades referentes ao Diagnōstico Bacterio lógico

A cada unidade compo nente da Rede caberā exercer funções preco nizadas e estabelecidas no item 6.4. deste trabalho, que salienta as atividades de cada Laboratório nos diferentes nīveis Central, Regional e Local, como também dos Pos tos de Colheita de Amostras. As técnicas básicas de bacteriologia da tuberculose serão realizadas de acordo com a capacidade operacional e técnica de cada Laboratório, mas fundamentalmente terão utilidade, segun do HERRERA MALMSTEN ${ }^{25}$, em quatro circunstān cias:

"1) Na descoberta de casos, ou seja, para se fazer o diagnóstico etiológico da tuberculose; 
2) na indicação terapêtica, ou seja, para indicar o esquema quimioterápico que pode conduzir com segurança a um percentual próximo a 100\% de êxito;

3) no controle da eficácia do esquema terapêutico prescrito;

4) para fazer o controle de cura do doente e decidir sobre quando lhe dar alta.".

As técnicas que serão utilizadas obedecerão àquelas padronizadas e recomendadas pela OPS/OMS no "Manual de Bacteriologia de la Tuberculosis - Técnicas y Proce dimientos Bāsicos"48, que foram parcialmen te transcritas no "Guia para el Diagnōstico de la Tuberculosis por el Examen Microscōpico"47 e na "Ação Antituberculose a Nĩ vel Periférico" 1 .

o exame microscópico direto de escarro serā o elemento prioritārio e fundamental de todo o processo de implantação, embora os estudos realizados por RAJ NARAIN e col. 42 e SANTIAGO52, indicam que a cul tura deve ser introduzida na rotina dos Laboratōrios de Bacteriologia da Tuberculose que constituirão a Rede.

Por ser o exame direto, elemento prioritário, as técnicas referentes à des- 
contaminação do material, cultura e testes de resistência aos quimioterāpicos, não serão temas deste estudo.

Os itens que se seguem sugerem 0 material, ārea de trabalho, equipamentos e tēcnicas bãsicas que deverão ser empregados nas atividades de diagnōstico bacteriolōgico.

A) AREA DE TRABALHO E MATERIAL

Todo o laboratōrio que realiza baciloscopia deve dispor de um espaço adequado, que variará de acordo com a categoria de serviços. As condiçōes minimas estabelecidas nas "Normas para os Laboratórios de Bacteriologia da Tuberculose"9 devem ser as seguintes:

- uma mesa de trabalho de $1,60 \times 0,60 \mathrm{~m}$, de material lavāiel, resistente aos ácidos e ao calor. Deverā possuir uma pequena pia com ralo;

- Uma caixa para lâminas;

- um recipiente para os aplicadores de madeira;

- aplicadores de madeira (quantidade necessāria para a realização da rotina);

- um bico de gās ou lâmpada à ālcool;

- um lāpis diamante ou demogrāfico;

- três vidros conta-gotas destinados aos rea- 
tivos (fucsina, azul de metileno, ālcoolàcido):

- papel de filtro (Watman nọ 1), para filtrar a fucsina:

- um latão metálico com tampa para incineracão:

- uma bandeja metālica.

B) EQUIPAMENTO PARA MICROSCOPIA

- um microscópio mono ou binocular:

- Uma lámpada como fonte de luz;

- uma pequena mesa para microscopia;

- um frasco conta-gotas para óleo de imersão;

$-\times i 101$;

- papel "yes", ou papel higiēnico fino, para limpar a objetiva de imersão;

- lista de trabalho com os nūmeros e nomes correspondentes às lāminas a observar e um caderno de papel rascunho;

- uma caixa vazia, onde serão colocadas as làminas já observadas:

- um bloco de formulário de pedidos de baciloscopia, que noderá servir tambēm para dar o resultado do exame. 
C) DISTRIBUICAAO E MANUTENCAO DO MATERIAL

Caberā ao Laboratōrio Central do Estado, sị tuado na Capital, a distribuição dos reativos, potes de co lheita de escarro e outros materiais, de acordo com o volu me de trabalho de cada Laboratório Regional. Poderāo La boratōrio Central recorrer à Coordenação da Rede para complementar seus recursos de material ou de reativos. E res ponsabilidade do Laboratōrio Central a oportuna reparação dos microscōpios utilizados nos seus serviços periféricos'.

A medida que se for efetivando a implantação, as atribuiçōes referentes ao Laboratōrio Central poderão paulatinamente ser assumidas pelo Laboratório Regional, de acordo com as funções especĩficas dos Laboratōrios Regionais salientadas no capitulo 6 , item 6.4 .2 .1$. , referentes à segunda etapa.

D) O METODO BACTERIOLOGICO

Os tōpicos referentes à amostra (colheita, conservação), assim como a preparação do esfregaço, coloração, observação microscōpica e informe dos resultados são detalhados nas "Normas para os Laboratórios de Bacterioscopia da Tuberculose" 9 , mas de maneira geral resumem-se no seguinte:

1. A Amostra

o laboratōrio que executa as tēcnicas bacte 
riológicas necessitarā de certos requisitos bā sicos quanto à amostra para poder fornecer resultados satisfatórios do ponto de vista tēcni co e dentro de um certo padrão de confiabilida de. Desta maneira, uma amostra é considerada de boa qualidade quando provēm da árvore brōnquica, quando colhida pela manhã (ao despertar do paciente), num recipiente descartável apropriado (FIGURA n? 18), e quando transportada adequadamente (FIGURA n : 19), evitando-se que o prazo entre a colheita e o processamento da amostra ultrapasse uma semana. Entretanto, durante este tempo, as amostras deverão se $r$ mantidas em refrigerador ou em qualquer lugar fresco e ao abrigo da luz.

FIGURA NO 18 - RECIPIENTE DESCARTAVEL DE PLASTICO (POte), INDICADO NA COLHEITA DE ES CARRO

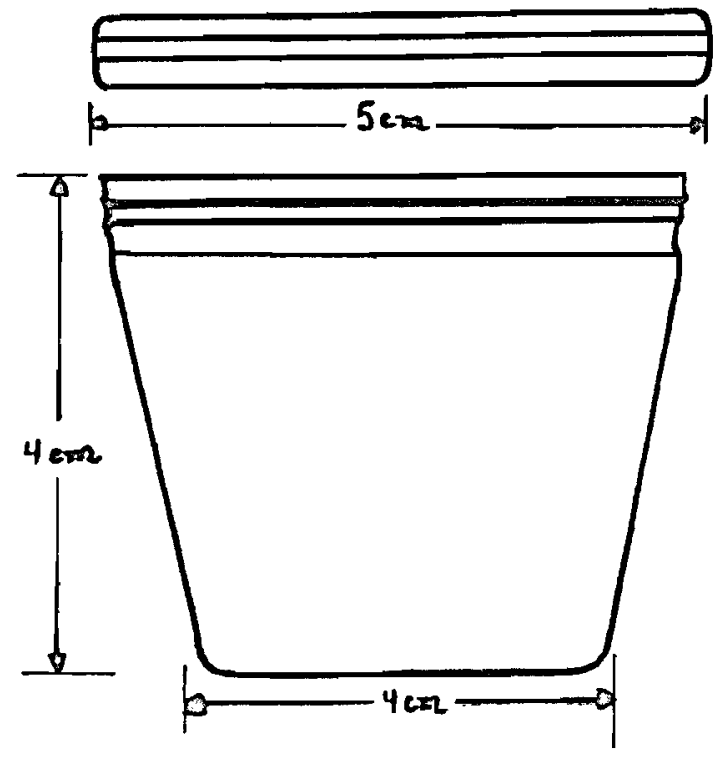


FIGURA NO 19 - CAIXA PARA TRANSPORTE DE AMOSTRAS.

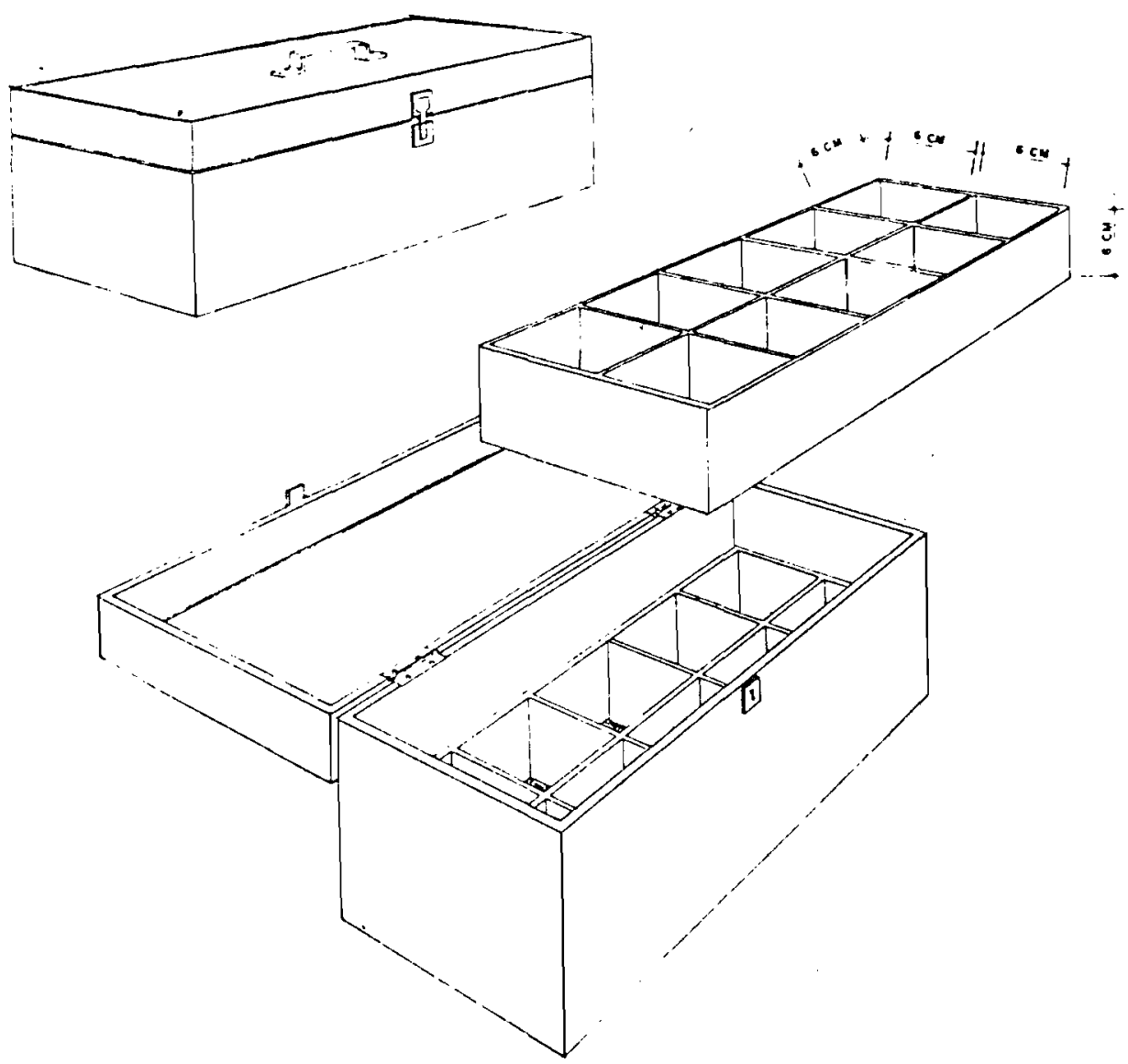

FONTE: "Normas para os laboratörlos de bacterios copia da tuberculose" (9).

\section{OExame Microscópico Direto}

\section{a) Preparação do esfregaço e coloração}

Dispor os materiais recebidos sobre a me sa de trabalho contendo folhas de papel toalha embebidas em solução de fenol de 5 a $10 \%$. Pre parar a lista de trabalho contendo os nomes dos pacientes dos quais as amostras serão examina- 
das. Numerar as làminas e potes correspondentes e colher a particula representativa do es carro com os aplicadores de madeira. Colocar o material sobre a lāmina, deixar secar à temperatura ambiente e fixar posteriormente pelo ca lor. Corar pelo mëtodo de Ziehl-Neelsen que, de maneira geral, consta das seguintes etapas:

I - cobrir a superfície do esfregaço com fucsi na fenicada;

II - aquecer suavemente o corante atē a emissão de vapores, por 3 vezes;

II - escorrer o corante;

IV - descorar com solução de ālcool-ācido;

V - lavar com āgua corrente;

VI - acrescentar azul de metileno, pelo menos por trinta (30) segundos (corante de fundo);

VII - lavar novamente e secar.

b) Observação microscōpica

As lāminas, devidamente coradas, serão observadas ao microscópio com objetivas de imersão $(100 x)$ e ocular de $8 \times$ ou $10 x$. os bacilos aparecerão no campo microscópico corados em vermelho, contrastando com um fundo azul celeste. Para a focalização tem-se necessidade de colocar entre a lämina e a objetiva 
de imersāo uma gota de ōleo de cedro ou óleomi neral (nujol) contido em frasco apropriado.

A leitura microscōpica com quantificação dos germes se processarā de duas maneiras:

I - Por campo microscōpico - dividir mentalmen te o campo em observação em quatro quadran tes (FIGURA no 20), iniciando-se a leitura pelo quadrante superior direito e continuando-a no sentido dos ponteiros do relógio nos demais quadrantes.

FIGURA nO 20 - QUADRANTES PARA OBSERVAÇÃO DE UM CAMPO MICROSCOPICO.

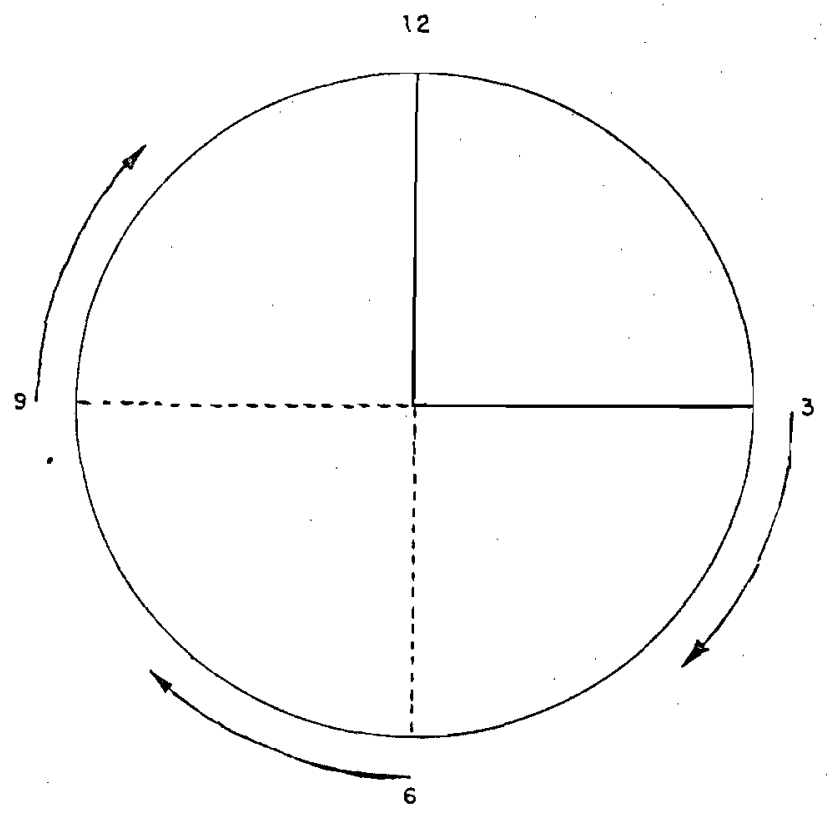

FONTE: "Normas para laboratörios de bacterios copia da tuberculose" (9).

II - Em nūmero determinado de campos - Recomenda-se a observação de um nūmero superior a 100 campos, o que demandaria a observação da lâmina por 5 minutos. Percorrer cerca de $2 / 3$ da lämina da esquerda para a dire 
ta, observando-se em uma linha reta, o que aproximadamente significa 100 campos (FIGURA $n$ : 21).

FIGURA N! 21 - TECNICA PARA LEITURA DE CEM CAMPOS MICROSCOPICOS



FONTE: "Normas Dara os laboratorios de bac terioscodia da tuberculose" (9).

Caso se observe de 1 a 4 bacilos nos primeiros cem campos, deve-se estender a leitu ra a outros cem campos, conforme fIGURA n? 22, totalizando desta forma 200 campos.

FIGURA NO 22 - TECNICA PARA LEITURA DE DUZENTOS CAMPOS MICROSCOPICOS



FONTE: "Normas para os laboratörios de bac terioscopia da tuberculose (9).

0 processo da contagem quantificada por cam pos microscōpicos é bastante sequro quando se anota em quadrículas (FIGURA no 23) o nū mero de bacilos encontrados em cada campo observado. 
FIGURA $\Pi$ ? 23 - DUADRTCULAS PARA A

CONTAGEM DE BACILOS

Esfregaco $N^{\circ}$

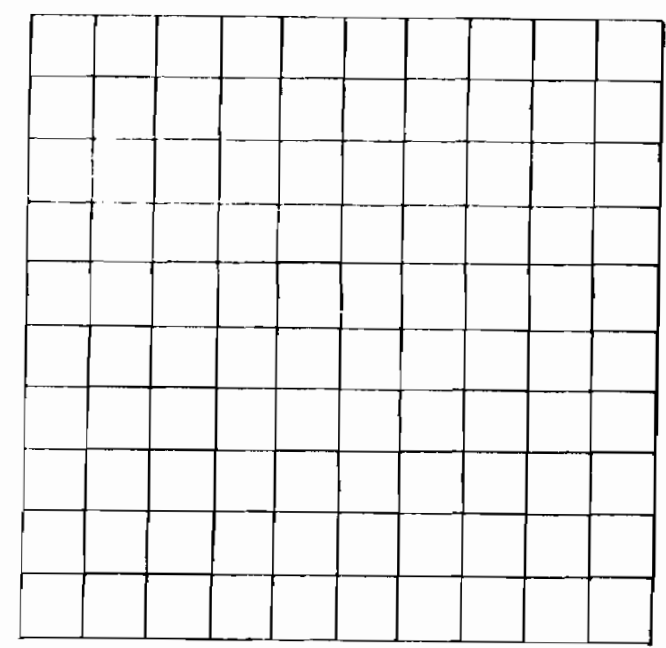

FONTE: "Normas para os laboratórios

de bacterioscopia da tuberculose (9).

c) Informe do resultado

0 informe do resultado do exame bacterioscōpico serā fornecido baseado na seguinte escala semiquantitativa:

(-) Não se encontram bacilos ālcool-ācido resistentes em cem campos microscōpicos observados;

$(+)$ Menos de um bacilo ālcool-ācido resistente por campo, em cem campos observados:

(++) Um a dez bacilos ālcool-ācido resistentes por campo, em cinquenta campos observados ;

$(+++)$ Mais de dez bacilos ālcool-äcido resistentes por campo, em vinte campos obser vados. 
A interpretação do informe baciloscópico durante o curso do tratamento serā baseada na TABELA n: 20), obedecendo-se as interpretações sugestivas de: evolução favorāvel, resistēncia inicial a todas as drogas e resistēncia inicial a algumas das drogas ou resistência se cundāria ao tratamento.

TABELA ne 20 - INTERPRETAÇÃO DO INFORME BACILOSCOPICO DURANTE O CURSO DO TRATAMENTO

\begin{tabular}{|c|c|c|c|}
\hline $\begin{array}{c}\text { MOMENTO } \\
\text { DO } \\
\text { EXAM E }\end{array}$ & $\begin{array}{c}\text { EVOLUçૈ̃o } \\
\text { FA VO R AVEL }\end{array}$ & $\begin{array}{l}\text { RESISTENCIA } \\
\text { INICIAL A TO } \\
\text { DAS AS DRO- } \\
\text { GAS USADAS }\end{array}$ & $\begin{array}{l}\text { RESISTENCIA I- } \\
\text { NICIAL A ALGU } \\
\text { MAS DROGAS OU } \\
\text { RESISTENCIA SE } \\
\text { CUNDARIA AO TRA } \\
\text { TAMENTO }\end{array}$ \\
\hline Inicial. & $++t$ & +++ & +++ \\
\hline 10 mês & $+t$ & $++t$ & +++ \\
\hline 20 mês & + & $++t$ & ++ \\
\hline 30 mês & $(-)$ & $+++(*)$ & + \\
\hline $4 \Omega \mathrm{mês}$ & $(-)$ & +++ & $(-)$ \\
\hline 50 mês & $(-)$ & & + \\
\hline 60 mès & $(-)$ & & $++(*)$ \\
\hline
\end{tabular}

(*) Nestes casos, pode-se solicitar cultura e prova de sensibilidade.

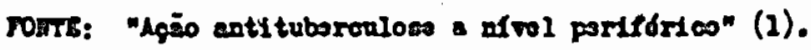


6.5 .3 . Custo

o cālculo do custo do processo bacteriolōg co, serā abordado em dois aspectos:

1) Cālculo das despesas para a aquisição do ma terial permanente necessārio à realização a penas de baciloscopia do escarro.

2) Cālculo do custo aproximado para se descobrir e controlar 1.295 casos de tuberculose, baseado fundamentalmente no exame direto do escarro.

O material permanente necessārio para a mon tagem de uma unidade padrão de baciloscopia, foi calculado levando-se em conta o material especificado nas "Normas para Laboratórios de Bacterioscopia da Tuberculose" 9 , que resume-se no seguinte:

- microscōpio

- fonte de luz

- frasco para óleo

- caixa para Láminas

- mesa para preparação do materiál

- pia comum

- lamparina à ālcool

- vidros corantes

- latão metālico

- bandeja metālica

- mesa para microscopia.

o custo do material especificado, excluindo se o microscōpio, é aproximadamente Cr\$685,00(seis 
centos e oitenta e cinco cruzeiros). Desta forma, - custo de uma unidade padrão de baciloscopia estā calculado em $\operatorname{Cr} \$ 11.685,00$ (onze mil, seiscene oitenta e cinco cruzeiros) e Cr\$14.385,00 (qua torze mil, trezentos e oitenta e cinco cruzeiros) respectivamente com microscópio mono e binocular.

o preço dos microscōpios foram baseados nos preços reais obtidos de casas comerciais, que trabalham com aparelhamento cientifico. No entanto, a Secretaria da Saúde do Estado de São Paulo, pode rā obtē-1os apenas por Cr\$ 4.070,00 (quatromil e setenta cruzeiros) e Cr $\$ 5.030,00$ (cinco mile trinta cruzeiros) respectivamente para os modelos mono e binocular. Este desconto se baseia na isen ção de impostos referentes ao Imposto de Circulação de Mercadorias, Imposto sobre Produtos Indus trializados e Taxas de Importação, totalizando 63\%. Baseado neste desconto, a unidade padrão de bacilos copia custaria aproximadamente Cr\$4.755,00 (quatro mil, setecentos e cinquenta e cinco cruzeiros.) e Cr\$5.715,00 (cinco mil, setecentos e quinze cru zeiros).

0 custo para o aparelhamento necessārio para a implantação da Rede de Laboratōrios de Bacte riologia da Tuberculose na DRS-6, foi calculado ba seando-se na instalação de apenas 16 unidades padrão, pois jā existem 4 unidade implantadas. 0 
total estaria em torno de $\operatorname{Cr} \$ 76.080,00$ (setenta e seis mil e oitenta cruzeiros) e Cr\$91.440,00 (noventa e um mil, quatrocentos e quarenta cruze ros) para o equipamento especificado.

Estimando-se que, para se encontrar e controlar 1.295 casos de tuberculose, apenas empregan do baciloscopia direta do escarro, teríamos que rea lizar um total de 25.900 baciloscopias e calculando-se que cada baciloscopia custa em média de Cr\$ 0,70 (setenta centavcs) dispenderíamos cerca de Cr\$ 18.830,00 (dezoito mil, oitocentos e trintacru zeiros).

Portanto, para uma cobertura populacional de 874.284 habitantes, equivalente à $59,9 \%$ e realizan do exames baciloscópicos em 20 laboratórios, gasta ríamos a quantia aproximada de Cr\$105.000,00 (cen to e cinco mil cruzeiros).

A DRS -6 jā possui em sua sede regional cer ca de 14 microscōpios novos, que serão distribuj dos aos vários distritos sanitārios. Portanto, o custo da implantação da Rede se reduziria à Cr\$. $29.000,00$ (vinte e nove mil cruzeiros) que acredi tamos que seja uma quantia bastante irrisōria, em função do benefício. 


\subsubsection{Treinamento de Pessoal}

Os atuais programas de luta contra a tuberculose jă especifican, entre os seus objetivos, o treinamento de pessoal, visto que, do ponto de vis ta da saūde pūblica, deve estar integrado às ativi dades gerais de saūde das Unidades Sanitárias. Mis ter se faz, portanto, que o pessoal que compõe estas Unidades receba orientação sobre o programa, as medidas de prevenção, diagnóstico e tratamento.

Considerando que o programa de ação contra a tuberculose tem mūltiplas atividades, torna-se necessário que todo o elemento que dele participa, receba conhecimentos sobre a problemática da doenca e não apenas sobre o que lhe vai ser atribuido como tarefa. Na ārea específica do laboratória, por exemplo, as pessoas que atuam nas diferentes ativi dades, deverão receber conhecimentos e serperiodicamente atualizadas sobre o programa geral e não simplesmente sobre sua ārea específica.

Informações especificas e restritas apenas a uma ārea de ação só dificultam o processo de integração e favorecem o fortalecimento de atividades isoladas, que prejudicam o programa como um todo.

A Rede de Laboratórios envolve atividades que vão desde a colheita de material, transporte, 
recebimento na Unidade Sanitāria, envio ao laboratōrio, execução do exame, informe do resultado, en caminhamento do resultado ao médico, até a convoca ção do doente positivo.

Conclui-se, portanto, que inūmeros integran tes da Unidade Sanitāria participam direta ou indi retamente da realização do exame de laboratōrio e que o resultado desse exame terá maior ou menor eficācia em função da participação de cada um.

Antes de especificarmos o treinamento pro priamente dito, convēm salientar que o pessoal que farā a rotina bacteriolōgica deve ser subdividido em duas categorias:

1) profissional universitário (bacteriologista): que exercerá funções de chefia no Laborató rio Central, e em todos os Laboratórios Regionais e em alguns Laboratōrios Locais;

2) Pessoal auxiliar: que executarā atividades técnicas, composto por técnicos de laboratōrio, auxiliares técnicos, atendentes ou qualquer pessoa da Unidade que tenha um mĩnimo de escolaridade e que possa ser treina da na realização de exames Taboratoriais.

Esta subdivisão em categorias torna-se necessāria para que o treinamento bāsico sobre tuber culose tenha amplitude diferente, dentro dos limites de conhecimento e atuação de cada elemento par ticipante. Propõe-se que o programa tenha uma par 
te geral e outra especifica correspondente a cada atividade, e que cada elemento da Unidade participe ativamente dentro de seu limite de conhecimen to e atribuiçōes.

0 programa de treinamento foi adaptado de estudos efetuados por VILLAS BOAS ${ }^{63}$ e ZANON e MAGA RAO ${ }^{64}$, representando o mínimo necessārio ao aprimo ramento técnico de cada elemento participante. E $\underline{a}$ presentado a seguir para (1) pessoal de nível pro fissional e (2) pessoal de nível auxiliar.

1) Programa de treinamento para equipe de profissionais composta de: médicos, enfermeiras, bacteriologistas (médicos, farmacêuticos-bioquímicos, veterinārios, biologistas) e educadores de saūde pública.

I. Conteūdo bāsico: noções e atualizações em :

a) epidemiologia da tuberculose;

b) diagnōstico bacteriolōgico;

c) tratamento:

d) prevenção (BCG e quimioprofilaxia);

e) educação em saúde pūblica;

f) programas de luta contra a tuberculose.

os assuntos serão enfocados de acordo com as normas específicas da "Ação Antituberculose a nível Periférico" 1 , relatados e exem plificados sempre dentro do campo da Saúde Püblica.

II. Conteúdo específico: dirigido aos profissionais que exercerão atividades para a implanta 
ção da Rede de Laboratōrios, limitadas a penas aos bacteriologistas:

a) micobactērias - caracteres gerais;

b) colheita do material (teoria e prāti ca) ;

c) preparação do esfregaço e coloração (prātica);

d) exigências nutritivas das micobactérias;

e) cultura (teoria e prātica);

f) testes de resistência aos antibióticos e quimioterāpicos (teoria e prātị ca);

g) micobactērias atīpicas; identificação; sua importância na Saūde Pūblica (teo ria).

A carga horária do treinamento, bem como o local onde se realizará (se a nível regional ou local), ficará a cargo da equipe que o ministrar, de acordo com as disponibilidades dos elementos participantes.

2) Programa de treinamento para pessoal auxiliar (destinado a técnicos de laboratōrio, atendentes, visitadoras sanitārias, outros profissionais de mesmo nivel):

I. Conteūdo bāsico: noções gerais de:

a) programa de tuberculose;

b) etiologia, transmissão e profilaxia da tuberculose; 
c) medidas diagnōsticas (de acordo com a regiāo e enfatizando a bacteriologia);

d) tratamento;

e) BCG e quimioprofilaxia;

f) educação para a saūde.

II. Conteūdo específico: exemplificadoe mos trado na prática e em campo, de acordo com o tipo de auxiliar, em sua área espe cífica. Deverá ser limitado às atividades relacionadas ao diagnóstico bacterio lógico.

a) A nível de técnicos, auxiliares de la boratório e possíveis baciloscopistas:

1. noçōes sobre mi cobactērias;

2. colheita de material (teoria e prá tica);

3. sintomáticos respiratórios;

4. preparação do esfregaço e coloração (prática);

5. microscopia (teoria e prātica);

6. cuidados com o microscópio;

7. recebimento do material, registro de dados e envio dós resultados;

8. levantamento estatistico mensal dos exames realizados;

9. controle dos casos em tratamento.

b) A nivel de atendentes e visitadores sanitários, visando ao diagnóstico bac teriológico:

1. colheita do material (teoria e prä tica);

2. descoberta e reconhecimento dos sin tomáticos respiratórios; 
3. recebimento da amostra;

4. controle dos doentes em tratamento.

A nivisão Reaional de Saūde de Ribeirão Preto (DRS-6) possui, em seu quadro de pessoal auxiliar, 4 tēcnicos de laboratōrio, 3 auxiliares tēcnicos e 319 atendentes, embora a Portaria SSCG no 8, de 6 de junho de 1972 , tenha previsto para aquela Divisão Regional 4 tēcnicos, 27 auxiliares tēcnicos e 341 atendentes. A TABELA n? 21 mostra estes dados.

\section{5 .5 . Supervisão}

\subsubsection{Consideracões Gerais}

Sunervisionar não sianifica apenas inspecionar ou fiscalizar. O conceito de supervisão deve ser difundido como um método mais de orientacão do que propriamente de repressão. Deverá ser realizada de tal forma que propicie ao supervisionado o aprimoramento de seus conhecimentos e exerça suas funçōes com maior eficiēncia e satisfá cão.

CAMARA 14 salienta que "a supervisão $\bar{e} 0$ processo realizado com o fim de controlar a aplica ção prática dos princīpios e normas que regem uma instituição, por meio de orientacão, instrucão e ajuda para conseguir maior eficiēncia". 


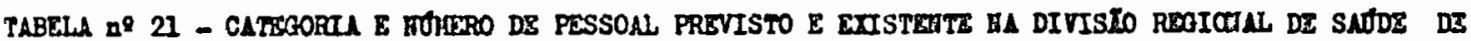
RIBETRTO PESTO, SBOUHDO A PORTLRTA SSCG ne 8, do 1972 - 1975.

\begin{tabular}{|c|c|c|c|c|c|c|c|c|c|}
\hline \multirow{2}{*}{\multicolumn{2}{|c|}{$\begin{array}{l}\text { Distritose } \\
\text { Hunicipios. }\end{array}$}} & \multicolumn{2}{|c|}{ Técnico } & \multicolumn{2}{|c|}{$\begin{array}{l}\text { Auxiliar } \\
\text { TECnico }\end{array}$} & \multicolumn{2}{|c|}{ Atendente } & \multicolumn{2}{|c|}{$\begin{array}{lllll} & 0 & \mathbf{T} & \mathrm{A} & \mathrm{L}\end{array}$} \\
\hline & & Prev. & Exist & Prev. & Exist & Prev. & Exist. & Prev. & Exist. \\
\hline 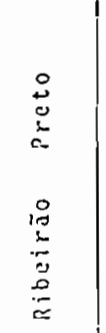 & $\begin{array}{l}\text { Barrinha } \\
\text { Cravinhos } \\
\text { Dumont } \\
\text { Luis Antonto } \\
\text { fontal } \\
\text { pradopolis } \\
\text { Rioeirao Preto } \\
\text { Sta.Rosa do Viterbo } \\
\text { Sao Sinão } \\
\text { Serra Azul } \\
\text { Serrana } \\
\text { Sertazinho }\end{array}$ & $\begin{array}{l}- \\
- \\
i \\
i \\
- \\
- \\
-\end{array}$ & $\begin{array}{l}: \\
: \\
- \\
i \\
: \\
: \\
-\end{array}$ & $\begin{array}{l}- \\
- \\
- \\
- \\
3 \\
- \\
- \\
2\end{array}$ & $\begin{array}{l}- \\
- \\
- \\
- \\
- \\
- \\
- \\
- \\
- \\
-\end{array}$ & $\begin{array}{r}3 \\
4 \\
3 \\
3 \\
4 \\
3 \\
15 \\
4 \\
4 \\
3 \\
3 \\
9\end{array}$ & $\begin{array}{r}6 \\
4 \\
1 \\
- \\
5 \\
1 \\
37 \\
6 \\
4 \\
1 \\
3 \\
5\end{array}$ & $\begin{array}{r}3 \\
4 \\
3 \\
3 \\
4 \\
3 \\
19 \\
4 \\
4 \\
3 \\
3 \\
11\end{array}$ & $\begin{array}{r}6 \\
4 \\
1 \\
5 \\
5 \\
1 \\
38 \\
6 \\
4 \\
1 \\
3 \\
5\end{array}$ \\
\hline $\begin{array}{l}\because \\
\vdots \\
0 \\
0 \\
0\end{array}$ & $\begin{array}{l}\text { Altinopolis } \\
\text { Batatais } \\
\text { Srodosqui } \\
\text { Cajury } \\
\text { Cassia dos Coqueiros } \\
\text { Cardinopolis } \\
\text { Sto.Antonio da Alegria }\end{array}$ & $\begin{array}{l}- \\
- \\
- \\
- \\
-\end{array}$ & $\begin{array}{l}- \\
- \\
- \\
- \\
-\end{array}$ & $\begin{array}{l}i \\
- \\
- \\
-\end{array}$ & $\begin{array}{l}- \\
- \\
- \\
- \\
-\end{array}$ & $\begin{array}{l}4 \\
5 \\
3 \\
4 \\
3 \\
4 \\
3 \\
\end{array}$ & $\begin{array}{l}4 \\
4 \\
4 \\
2 \\
1 \\
5 \\
1\end{array}$ & $\begin{array}{l}4 \\
6 \\
3 \\
4 \\
3 \\
4 \\
3\end{array}$ & $\begin{array}{l}4 \\
4 \\
4 \\
2 \\
1 \\
5 \\
1 \\
\end{array}$ \\
\hline 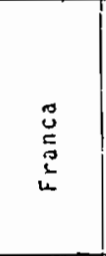 & 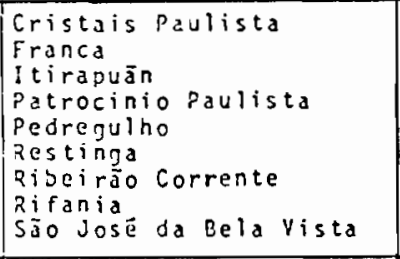 & $\begin{array}{l}- \\
- \\
- \\
- \\
- \\
-\end{array}$ & $\begin{array}{l}- \\
- \\
- \\
- \\
- \\
- \\
-\end{array}$ & $\begin{array}{l}- \\
3 \\
- \\
- \\
- \\
- \\
-\end{array}$ & $\begin{array}{l}- \\
- \\
- \\
- \\
- \\
- \\
-\end{array}$ & $\begin{array}{r}3 \\
15 \\
3 \\
4 \\
4 \\
3 \\
3 \\
3 \\
3\end{array}$ & $\begin{array}{r}2 \\
18 \\
4 \\
5 \\
3 \\
1 \\
1 \\
1 \\
3\end{array}$ & $\begin{array}{r}3 \\
19 \\
3 \\
4 \\
4 \\
3 \\
3 \\
3 \\
3\end{array}$ & $\begin{array}{r}2 \\
18 \\
4 \\
5 \\
3 \\
1 \\
1 \\
1 \\
3\end{array}$ \\
\hline $\begin{array}{l}0 \\
2 \\
5 \\
\vdots \\
3 \\
3 \\
\vdots\end{array}$ & $\begin{array}{l}\text { Aramina } \\
\text { Guritizal } \\
\text { Guara } \\
\text { lgarapava } \\
\text { I tuverava } \\
\text { igiguelopolis } \\
\text { Jeriquara }\end{array}$ & $\begin{array}{l}- \\
- \\
- \\
-\end{array}$ & $\begin{array}{l}- \\
- \\
- \\
-\end{array}$ & $\begin{array}{l}- \\
- \\
i \\
1 \\
-\end{array}$ & $\begin{array}{l}- \\
- \\
- \\
- \\
- \\
-\end{array}$ & $\begin{array}{l}3 \\
3 \\
4 \\
5 \\
5 \\
4 \\
3\end{array}$ & $\begin{array}{l}3 \\
1 \\
3 \\
5 \\
5 \\
3 \\
1\end{array}$ & $\begin{array}{l}3 \\
3 \\
4 \\
6 \\
6 \\
4 \\
3\end{array}$ & $\begin{array}{l}3 \\
1 \\
3 \\
6 \\
3 \\
3 \\
1\end{array}$ \\
\hline 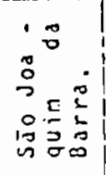 & $\begin{array}{l}\text { Ioja } \\
\text { Vorro Agudo } \\
\text { uuporanga } \\
\text { orlandia } \\
\text { Sales de Olivelra } \\
\text { Sajo Joaquim da Barra }\end{array}$ & $\begin{array}{l}- \\
- \\
- \\
-\end{array}$ & $\begin{array}{l}- \\
- \\
- \\
-\end{array}$ & $\begin{array}{l}- \\
- \\
- \\
i\end{array}$ & $\begin{array}{l}- \\
- \\
- \\
-\end{array}$ & $\begin{array}{l}4 \\
4 \\
3 \\
4 \\
3 \\
5\end{array}$ & $\begin{array}{l}1 \\
3 \\
2 \\
5 \\
3 \\
6\end{array}$ & $\begin{array}{l}4 \\
4 \\
3 \\
4 \\
3 \\
6\end{array}$ & $\begin{array}{l}1 \\
3 \\
2 \\
5 \\
3 \\
6\end{array}$ \\
\hline $\begin{array}{l}0 \\
\stackrel{0}{0} \\
\vdots \\
\vdots \\
0 \\
0\end{array}$ & $\begin{array}{l}\text { Barretos } \\
\text { Colina } \\
\text { Colonbia } \\
\text { ruaira } \\
\text { Jaborandi }\end{array}$ & $\begin{array}{l}1 \\
- \\
- \\
-\end{array}$ & $\begin{array}{l}- \\
- \\
-\end{array}$ & $\begin{array}{l}3 \\
- \\
i \\
-\end{array}$ & $\begin{array}{l}1 \\
- \\
- \\
-\end{array}$ & $\begin{array}{r}15 \\
4 \\
3 \\
3 \\
3\end{array}$ & $\begin{array}{r}14 \\
3 \\
5 \\
3 \\
3\end{array}$ & $\begin{array}{r}19 \\
4 \\
3 \\
0 \\
3\end{array}$ & $\begin{array}{r}15 \\
3 \\
5 \\
3\end{array}$ \\
\hline $\begin{array}{l}- \\
0 \\
0 \\
0 \\
0 \\
0 \\
0 \\
0 \\
0 \\
2\end{array}$ & $\begin{array}{l}\text { Fernando Prestes } \\
\text { Candido Rodrigues } \\
\text { Guariba } \\
\text { Jaooticabal } \\
\text { Vonte Alto } \\
\text { Sta. Ernestina } \\
\text { Taquaritinga } \\
\text { Vista Alegre do Alto }\end{array}$ & $\begin{array}{l}- \\
- \\
- \\
- \\
-\end{array}$ & $\begin{array}{l}- \\
- \\
- \\
- \\
- \\
-\end{array}$ & $\begin{array}{l}- \\
\overline{2} \\
- \\
i \\
-\end{array}$ & $\begin{array}{l}- \\
- \\
- \\
- \\
i \\
-\end{array}$ & $\begin{array}{l}3 \\
3 \\
4 \\
9 \\
4 \\
3 \\
5 \\
3\end{array}$ & $\begin{array}{r}2 \\
1 \\
3 \\
11 \\
4 \\
-7 \\
-\end{array}$ & $\begin{array}{r}3 \\
3 \\
4 \\
11 \\
4 \\
3 \\
6 \\
3\end{array}$ & $\begin{array}{r}2 \\
1 \\
3 \\
11 \\
4 \\
- \\
8 \\
-\end{array}$ \\
\hline $\begin{array}{l}0 \\
\frac{1}{3} \\
0 \\
0 \\
0 \\
0 \\
0 \\
0 \\
0\end{array}$ & $\begin{array}{l}\text { Bebedouro } \\
\text { Honte Azul Paulista } \\
\text { Piranji } \\
\text { Pitangueiras } \\
\text { Ta iacu } \\
\text { Tajuva } \\
\text { Terra Roxa } \\
\text { Viradouro }\end{array}$ & $\begin{array}{l}- \\
- \\
- \\
- \\
- \\
-\end{array}$ & $\begin{array}{l}1 \\
- \\
- \\
- \\
- \\
- \\
-\end{array}$ & $\begin{array}{l}2 \\
- \\
- \\
- \\
- \\
-\end{array}$ & $\begin{array}{l}- \\
- \\
- \\
- \\
- \\
-\end{array}$ & $\begin{array}{l}9 \\
3 \\
3 \\
4 \\
3 \\
3 \\
3 \\
3\end{array}$ & $\begin{array}{r}10 \\
2 \\
2 \\
5 \\
1 \\
2 \\
3 \\
3\end{array}$ & $\begin{array}{r}11 \\
3 \\
3 \\
4 \\
3 \\
3 \\
3 \\
3\end{array}$ & $\begin{array}{r}11 \\
2 \\
2 \\
5 \\
1 \\
2 \\
3 \\
3\end{array}$ \\
\hline $\begin{array}{l}0 \\
2 \\
0 \\
2 \\
0 \\
0 \\
2 \\
2 \\
2 \\
2\end{array}$ & 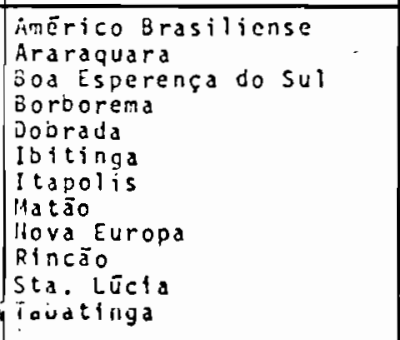 & $\begin{array}{l}- \\
- \\
- \\
- \\
- \\
- \\
- \\
-\end{array}$ & $\begin{array}{l}- \\
- \\
: \\
- \\
- \\
- \\
-\end{array}$ & $\begin{array}{l}- \\
- \\
- \\
- \\
1 \\
1 \\
- \\
- \\
-\end{array}$ & $\begin{array}{l}- \\
- \\
- \\
- \\
- \\
- \\
- \\
- \\
-\end{array}$ & $\begin{array}{l}3 \\
\\
3 \\
3 \\
3 \\
5 \\
5 \\
4 \\
3 \\
3 \\
3 \\
3\end{array}$ & $\begin{array}{l}1 \\
3 \\
2 \\
3 \\
1 \\
6 \\
5 \\
3 \\
1 \\
2 \\
2 \\
1\end{array}$ & $\begin{array}{l}3 \\
5 \\
3 \\
3 \\
3 \\
6 \\
6 \\
4 \\
3 \\
3 \\
3 \\
3\end{array}$ & $\begin{array}{l}1 \\
5 \\
2 \\
3 \\
1 \\
6 \\
5 \\
3 \\
1 \\
2 \\
2 \\
1\end{array}$ \\
\hline $\ln _{n} \frac{n}{0}$ & 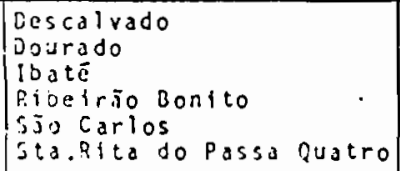 & $\begin{array}{l}- \\
- \\
i \\
-\end{array}$ & $\begin{array}{l}- \\
- \\
i \\
-\end{array}$ & : & $\begin{array}{l}- \\
- \\
- \\
-\end{array}$ & $\begin{array}{r}4 \\
3 \\
3 \\
3 \\
15 \\
5\end{array}$ & $\begin{array}{r}5 \\
2 \\
2 \\
2 \\
20 \\
0\end{array}$ & $\begin{array}{r}4 \\
3 \\
3 \\
3 \\
19 \\
6\end{array}$ & $\begin{array}{r}5 \\
2 \\
2 \\
2 \\
22 \\
6\end{array}$ \\
\hline & IOIAL & 4 & 4 & 27 & 3 & 341 & $31 \%$ & 308 & 325 \\
\hline
\end{tabular}


Segundo HERRERA MALMSTEN ${ }^{27}$, a supervisão é mētodo de trabalho idealizado nara manter a perma nente eficācia de uma Rede de serviços organizados, que implica em superviqiar, coordenar, corrigir, en sinar, estimular e avaliar os servicos supervisionados.

A sunervisãn de vārios serviços de uma Rede de Laboratōrios de Pacteriologia da Tuberculose de ve sempre ser dirigida basicamente ao pessoal tēcnico, procurando-se na ocasião observar os métodos empreșados, o material, as técnicas de trabalho e finalmente o local onde se realizamas atividades de rotina.

Alguns princīpios bāsicos devem ser levados em conta pelo supervisor, no que diz respeito à sua sua pessoa e às técnicas que utilizará27.

1. O supervisor não deverā limitar-se apenas a dar indicações que permitam solucionar um problema específico, mas ensinar os princípios bāsicos que estão relacionados com a causa destes problemas:

2. O supervisor deve ter como características básicas a amplitude de conhecimentos, o sen tido de responsabilidade, alēm de ser ativo, imparcial, discreto, tolerante, otimista, ter iniciativa, autoridade, modéstia, espīrito de conservação, entusiasmo e confiança em si mesmo;

3. A supervisão deve sempre estar baseada mais 
em relações profissionais do que em relaçōes pessoais;

4. Hā necessidade de se colocar os individuos supervisionados a par dos objetivos finais do programa, dos objetivos dos serviços em que trabalham, enaltecendo as responsabilidades dos mesmos frente à coletividade, valorizando o seu trabalho em relação ao paci ente, à famîlia e à comunidade;

5. A supervisão deve preocupar-se em estimular - bem estar do pessoal e as relações amisto sas entre seus membros;

6. Deve a supervisão ser planejada a curto e longo prazo, estabelecendo os recursos disponiveis e os meios de ação;

7. Deve realizar-se com sensibilidade e informalidade, utilizando procedimentos práticos;

8. Deve ser gradual, progressiva e persistente, e realizar-se de acordo com as necessidades;

9. Deve ser um processo agradāvel, que oriente e eduque o supervisionado, que solucione problemas, que possa descobrir as deficiências e saiba reconhecer os êxitos e progres sos alcançados;

10. Deve preocupar-se em assegurar aos funciona rios os meios de trabalho indispensáveis pa ra que possam realizar sua missão de forma digna e eficaz. 


\title{
6.5.5.2. Técnicas de Supervisão
}

\begin{abstract}
Existem dois métodos para se efetü ar a supervisão: a técnica direta e a indireta.
\end{abstract}

\section{5 .5 .2 .1 . Supervisão direta}

Quando é realizada pelo supervisor diretamente no local do laborató rio superviosionado. Trēs fatores deverão ser observados, e que são comuns à todo laboratörio 27 :

I. Fatores bãsicos
a) Local
b) Pessoal
c) Equipamentos e reativos
d) Coordenação com a rede
e) Cobertura da população
f) Relação com equipe de tuberculose.

II. Fatores administrativos
a) Organização interna
b) Sistema de registro
c) Utilizacão de formulārios
d) Entrega de resultados
e) Informação estatística.

III. Fatores tēcnicos
a) Baciloscopia
b) Cultivo 
c) Estudo de resistência

d) Tipificação

e) Preparação do material.

Aos laboratōrios que realizam apenas baciloscopia, levar em conta somente o primeiro tópico (a) do item III.

Cada laboratōrio deverā dispor de um livro ou caderno para registro da rotina diāria, com dados especificados no ANEXO 1 . Os pedidos de baciloscopia, que poderão ser vir tambēm para o informe do resultado do exame, serão confeccionados conforme modelo do ANEXO II. O formulārio para supervisão, como também alguns aspectos que deverão ser levados em conta por ocasião da visita do supervisor ao laboratōrio supervisionado, es tão colocados no ANEXO III.

$$
0 \text { critério de classificação para }
$$
cada laboratōrio supervisionado obedecerā aos coeficientes e valores absolutos relatados no ANEXO III, estabelecendo-se a mesma clas sificação empregada por DIAS FILHO ${ }^{17}$, na Guanabara. E a seguinte:

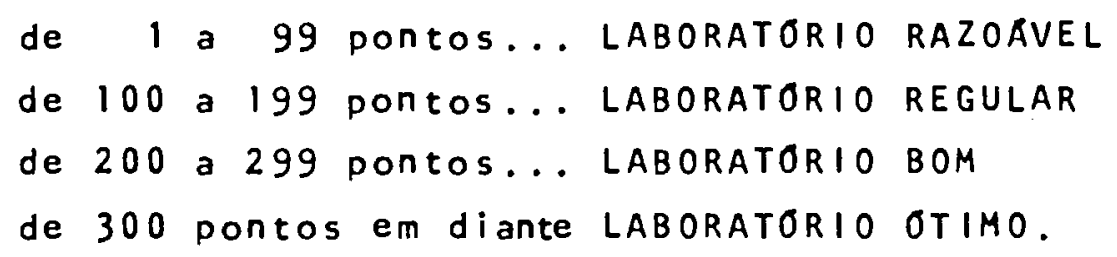




\section{5 .5 .2 .2 . Supervisão indireta}

Supervisão indireta é aquela que se processa à distância atravēs dos procedimentos 27 :

a) Envio de lâminas coradas negativas e positivas do laboratório supervisionado ao laboratōrio supervisor, para comparação dos resultados.

b) Envio de lâminas do laboratōrio de nīvel Local para o laboratório de nīvel Regional ou Central, para serem revisadas e comparados os resultados.

c) Anālise permanente qualitativa e quantitativa dos formulārios estatísticos dos diferentes serviços (laboratōrios), para determinar variações bruscas que façam pensar em possíveis desajustes de seu trabalho normal.

d) Permanente contato com os técnicos de ca da laboratōrio, atravēs de correspondência sistemātica.

e) Uso de serviço telefōnico para resolver os casos de emergência.

Recomenda-se a supervisão direta, caso os problemas específicos de cada laboratōrio não possam ser resolvidos pelos tópicos relatados anteriormente. 
o envio periōdico das lāminas do laboratōrio supervisionado ao laboratōrio supervisor serā realizado mensalmente ou a critério do laboratório supervisor, devendo ser enviados $10 \%$ do total de 1 áminas negati vas e todas as 1 àminas positivas. As lāminas positivas serão acompanhadas de suas respectivas quadriculas de contagem, onde se encontra especificado quantitativamente o nūmero de bacilos, visando com isso facilitar a supervisão. Deve-se ter o cuidado de remover o óleo de cedro, com o auxilio de papel absorvente exilol, e envolvê-las de maneira que fiquem separadas uma das ou tras. Recomenda-se fazer um pacote separado contendo as lâminas positivas eutro com as negativas.

Na supervisāo indireta, a qualidade dos resultados deverā ser estudada atra vēs de teste seletivo, avaliando atributos de sensibilidade e especificidade, definindo-os da seguinte forma ${ }^{60}$ :

a) sensibilidade: como a habilidade do mi croscopista de assinalar bacilos älcoolācido resistentes, quando eles realmente existem no esfregaço.

b) especificidade: como sendo a habilidade do microscopista de não assinalar baci- 
$105 \bar{a} l c 00 l-\bar{a} c i d o$ resistentes, quando eles realmente não existem no esfreaco.

Para a elaboracão do cālculo de sen sibilidade e esnecificidade entre as làmi nas enviadas nelo laboratório supervisiona do, e o resultado observado pelo laboratō rio sunervisor (Laboratōrio Referēncia) deve-se lançar mão da "classificacão quādrupla" adaptada de ThORNER \& REMEIN ${ }^{60}$ que ē mostrada na TABELA n: 22.

TABELA n尺 22 - "CLASSIFICAÇÃ QUÁDRU PLA" DOS RESULTADOS, SEGUNDO O LABORAT6RIO REFERENCIA E O LABORATÓRIO SUPERVISIONADO - 1975

\begin{tabular}{l|c|c|c}
\hline L A B O RA TORIO & \multicolumn{2}{|c|}{$\begin{array}{c}\text { LABORATÓRIO } \\
\text { REFER EN CIA }\end{array}$} & T O T A L \\
\cline { 2 - 4 } SUPERVISIONADO & Positivo & Negativo & \\
\hline - Positivo ... & $a$ & $b$ & $a+b$ \\
- Negativo ... & $c$ & $d$ & $c+d$ \\
\hline - T o T A L .. & $a+c$ & $b+d$ & $a+b+c+d$ \\
\hline FONTE: Adaptado de THORNER \& REMEIN (6o).
\end{tabular}

$$
\begin{aligned}
& A-\operatorname{SENSIBILIDADE}: \frac{a}{a+c} \times 100 \\
& B-\text { ESPECIFICIDADE: } \frac{d}{b+d} \times 100
\end{aligned}
$$


Considerando-se:

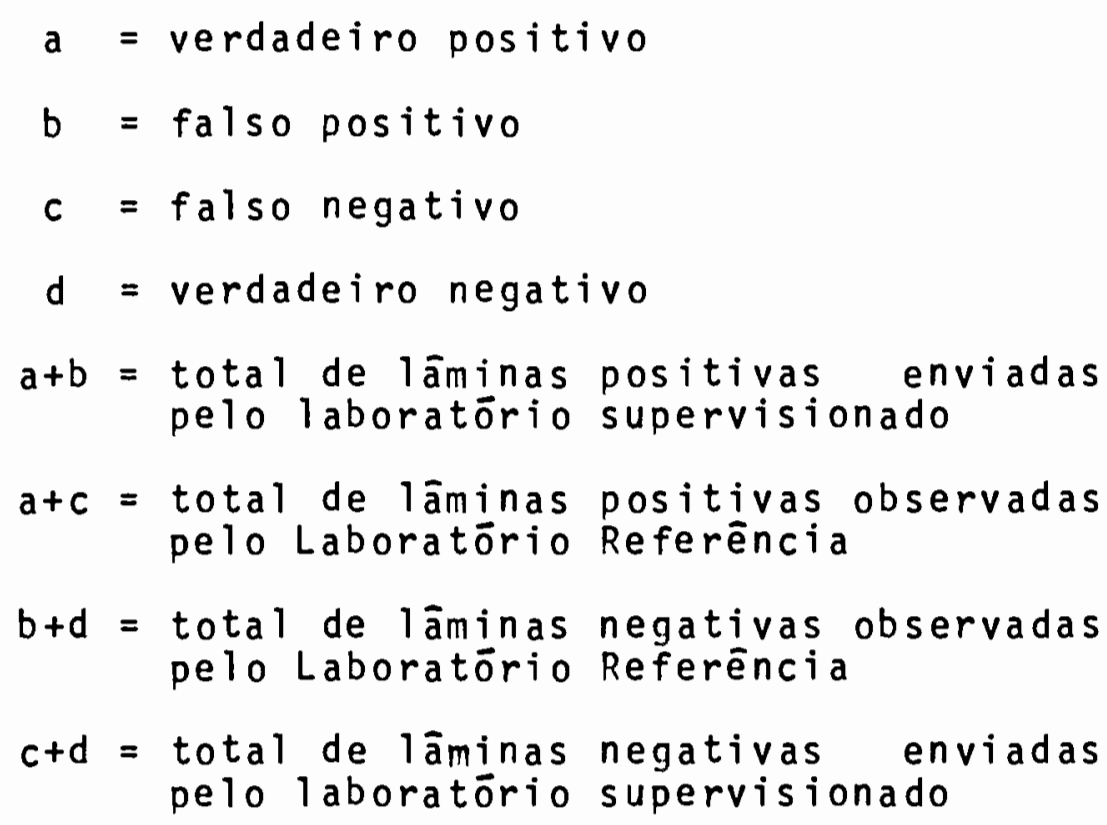

0 resultado da supervisão indireta seria anotado pelo laboratōrio supervisor, seguindo-se o seguinte critério:

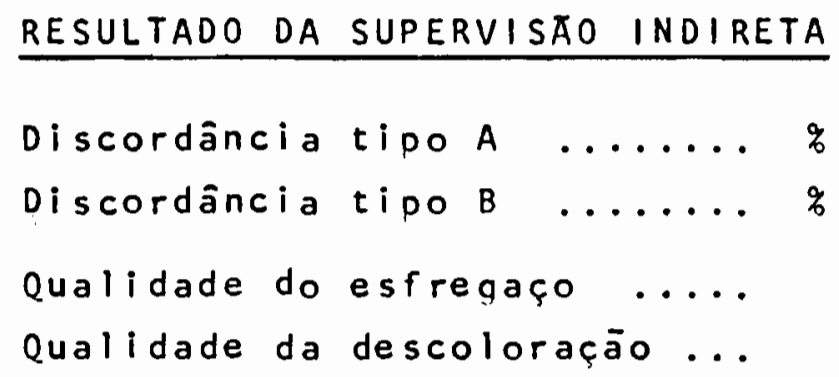

Conclui-se, portanto, que a supervisão poderā ser feita direta e indiretamen te. As atribuições e atividades de cada la boratōrio pertencente ā Rede poderão ser de talhadas e especificadas de acordo com suas respectivas capacidades técnicas, operacionais e pessoal. De qualquer forma, a super 
visão deverā sempre obedecer a uma ordem hie rārquica, isto é, o Laboratōrio central supervisionando todos os Laboratórios Regionais e estes, por sua vez, supervisionando os Laboratórios Locais.

Na Divisão Regional de Saūde de Rị beirão Preto (DRS-6) a supervisão se processarā obedecendo-se o mesmo critério hierárquico estabelecido, isto é, o Laboratório Regional do Instituto Adolfo Lutz, situado na cidade de Ribeirão Preto, farā a supervisão direta e indireta dos Laboratórios Locais, e estes, por sua vez, deverão supervisionar os Postos de Colheita de Amos tras ( $P C A)$ de sua respectiva jurisdição, levando-se em conta os seguintes aspectos:

a) AMOSTRA: Verificar quanto à:

$\begin{array}{ll} & \square \text { Saliva } \\ \text { QUALIDADE } & \square \text { muco } \\ & \square \text { mucopurulenta } \\ & \square \text { insuficiente } \\ \text { QUANTIDADE } & \square \text { pouco } \\ & \square \text { bom } \\ & \square \text { muito }\end{array}$


b) COLHEITA E CONSERVACAO: Observar como foi:

$\begin{array}{ll}\text { COLHIDA } & \square \text { naturalmente } \\ & \square \text { por drenagem postural } \\ & \square \text { outro método } \\ \text { CONSERVADA } & \square \text { lugar fresco } \\ & \square \text { refrigerador } \\ & \square \text { qualquer lugar }\end{array}$

c) RECIPIENTE (pote): Averiguar quanto a:

$\begin{aligned} & \square \text { na tampa } \\ \text { IDENTIFICAÇAO } \quad \square \text { no corpo do pote } & \square \text { Iegível } \\ & \square \text { não legível }\end{aligned}$

ACONDICIONAMEN $\square$ bem acondicionado
TOP/TRANSPORTE $\square$ mal acondicionado

d) TRANSPORTE: Verificar quanto a:

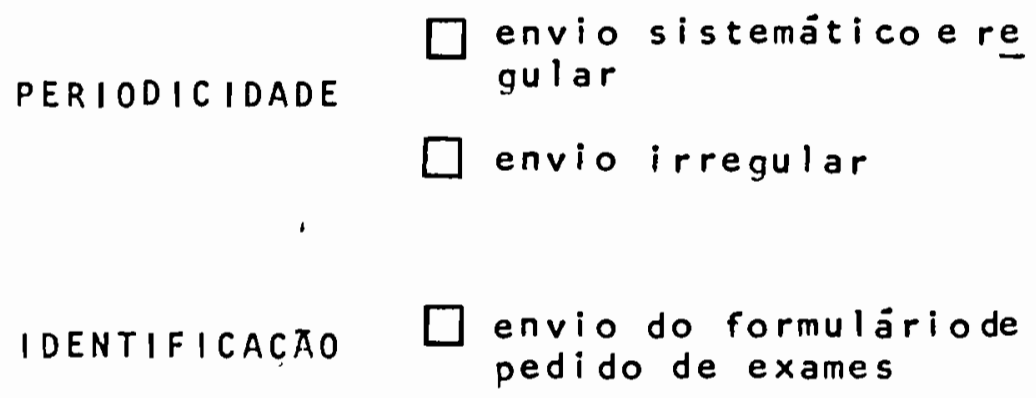


e) SINTOMATICOS RESPIRATORIOS: Indagar sobre:



6.5.6. Avaliação

A avaliação das atividades relativas à Rede de Laboratórios se processarā em termos quantitati vos, qualitativos e se desenvolverá visando basica mente três itens, estipulados como atividades do Programa Interestadual "Coração do Brasil" de Controle da Tuberculose 26 , que são os seguintes:

1. Avaliação dos serviços (Polo e Satēlite);

2. Avaliação do treinamento de pessoal;

3. Avaliação do sistema de supervisão.

\subsubsection{Avaliacão dos Serviços}

Para a avaliação dos serviços, deve-se determinar os serviçosque funcionarão como "Serviços Polos", isto é, os Laboratōrios Locais que se farão necessārios para toda uma região, verificando-se os que estão programados e os que serão implantados, usando-se como indicador a seguin 
te fórmula:



Para a DRS-6 estão programados 20 Servicos Polo, ou seja, 19 Laboratōrios Locais e 1 Regional, que poderão ser implantados à medida das possibilidades locais. Desta maneira podemos colocar de acordo com a fórmula anterior:

$$
\begin{aligned}
& \text { SERVICOS } \\
& \text { POLO }
\end{aligned}=\frac{\text { ? de servicos implantados }}{20^{\circ}} \times 100
$$

estabelecendo-se as metas necessārias para c a da mès ou ano e avaliando-se através dos indicadores.

Além da avaliacão dos servicos implantados, deve-se estimar tambēm o nūmero de exames baciloscó picos efetuados em nacientes sintomāticos respiratō rios, que apresentem tosse e expectoração por mais de duas a très semanas. 0 indicador será:

$\begin{aligned} & \text { SERVI }{ }^{\circ} \\ & \text { POLO }\end{aligned}=\frac{n ! \text { de exames efetuados }}{n ! \text { de exames previstos }} \times 100$

Para os "Serviços Satēlite" (PCA), a programação na DRS-6 foi estipulada em 60 unidades satél 1 tes, ou seja, 60 Postos de Colheita de Amostras (PCA), que deverão funcionar integrados com seus respecti- 
vos "Serviços Polos". Neste caso a avaliação seria da seguinte maneira:

$\begin{aligned} & \text { SERVICOS } \\ & \text { SATELITES }\end{aligned}=\frac{n \text { ? de PCA imolantados }}{60} \times 100$

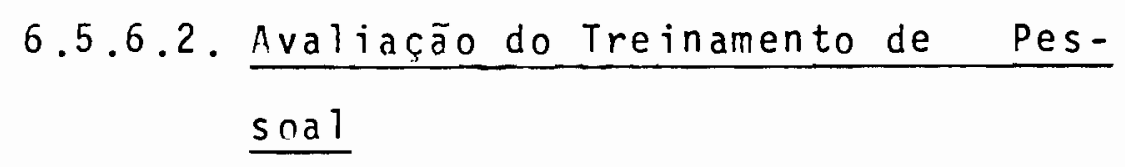

Na avaliação do treinamento de pes soal necessārio à Rede de Laboratōrios, deve-se de terminar o número de laboratoristas (de nível universitārio ou não) aue serão necessārios a todos os Laboratórios Locais e ao Laboratōrio Regional, além do treinamento de atendentes, auxiliares de enfermagem e visitadoras sanitārias necessärias aos diversos Postos de Colheita de Amostras (PCA), estabelecendo-se daí a programação e avaliando de acordo com os indicadores:

TRE I NAMENTO DE PESSOAL

$=\frac{n ! \text { laboratoristas treinados }}{n \text { ! laborato } r_{i} \text { stas programados }} \times 100$



Para a DRS-6 estão programados 22 laborato ristas e aproximadamente 120 elementos (visitadores, atendentes e auxiliares de enfermagem) para 
os Postos de Colheita de Amostras (PCA) para cumprirem as metas de implantação da Rede em toda a região. Desta maneira, a avaliação seria especifi cada da seguinte forma:

TREINAMENTO no laboratoristas treinados
DE PESSOAL $\frac{22}{22}$



6.5.6.3. Avaliação do Sistema de Supervisão

A avaliação do Sistema de Supervisão serā feita atravēs de indicadores que estimem a supervisão direta e indireta. Na supervisão direta serão designados os laboratōrios supervisiona dos, Tevando-se em conta os laboratórios impiantados. Desta forma, a avaliação seria em função da periodicidade das supervisōes e o nūmero de labora tórios implantados.

No caso da supervisão direta, os indicadores seriam: 




ne de laboratórios sudervisio
$=\frac{\text { nados aos } 30 \text { dias }}{\text { ne de laboratórios supervisio }}$
nados pela la vez

n: de laboratórios supervisio

$=\frac{\text { nados aos } 90 \text { dias }}{\text { n de laboratórios supervisio }} \times 100$ nados pela $2 a$. vez

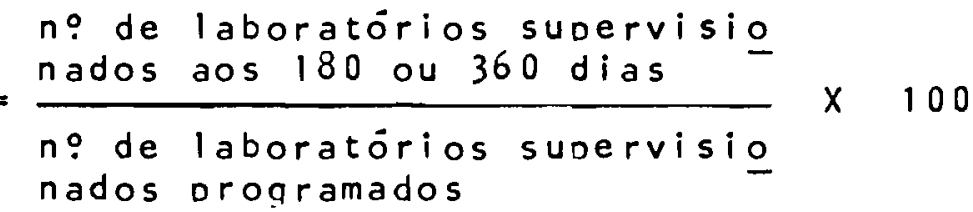

Desta forma, poder-se-ia avaliar as supervisões diretas efetuadas respectivamente aos 15 di as, no 10, 3o, 6ọ e 120 meses apōs à implantação. ila supervisão indireta, o indicador seria o seguinte:

SUPERVISAO

n: de laboratörios que enviam I NDIRETA 1 âminas n: de laboratórios implantados $\times \quad 100$

Deve-se, portanto, lançar mão do sistema de avaliação quantitativo, para que se possa estimar se o processo de implantacão da Rede de Laboratórios realmente se efetivou ou não. A avaliação qua 
litativa incidirā sobre o que se tem realizado em nīvel de supervisāo, visando que esta jā avaliou qualitativamente a metodologia empregada. Deve-se salientar, no entanto, que os percentuais encontra dos na avaliação quantitativa algumas vezes podem se distanciar das metas orogramadas, nāo signifi cando, entretanto, que o processo falhou; apenas que alguns pontos devem ser esclarecidos, ou que as atividades estipuladas devem ser reformuladas. 


\section{COMENTARIOS}

I. Os programas de luta contra a tuberculose devem adotar uma estratégia em função da situação epidemiológica da doença no meio em que vão atuar. Desta maneira, os métodos diagnósticos deverão sofrer a mesma alteração, a fim de preencher os objetivos dos programas.

0 advento dos modernos quimioterāpicos propiciou uma mu dança radical na metodologia diagnóstica, mostrando que a tuberculose é curāvel em qualquer fase de sua evoluçāo.

A radiologia de massa que já teve no passado sua indica ção prioritāria, com o fim de diagnosticar as formas iniciais da doença, cedeu lugar aos métodos bacteriológi cos, pela sua maior viabilidade em Saūde Pūblica, em termos de custo e beneficio propiciados.

Para tanto, ē necessārio haver uma transformação da cons ciēncia mēdica tradicional, das equipes das Unidades Sa nitārias e da prōpria população em relação à eficãcia dos mētodos bacteriológicos.

11. Para que programas de luta contra a tuberculose alcancem seus objetivos, tem-se necessidade de dar-lhes maior 
poder de penetração, atingindo āreas urbanas e rurais, obedecendo as necessidades reais da população, no que diz respeito à demanda, alēm de oferecer uma ajuda permanente a essa população. O método bacteriológico ē no momento epidemiológico atual a ūnica arma diagnōstica realista6l capaz de conseguir uma cobertura populacional eficiente, pois, alēm de ser um mētodo simples, de fãcil execução, cujo abarelhamento é barato, pode ser manuseado por técnicos com escolaridade minima, preenche totalmente aspectos de ordem epidemiológica, social, econōmica e técnica exigidos aos programas nacionais de controle.

III. O mētodo radiológico para fins exclusivos de diagnóstico da tuberculose deve ser realizado somente em grupos selecionados, o que certamente aumentarā o seu rendimen to ${ }^{4}$. Radiografar indiscriminadamente toda uma população com base apenas no conceito de que o processo tuber culoso se desenvolve lentamente e que desta maneira po deríamos surpreender o processo na sua fase inicial, não leva à diminuição do nūmero de casos; os indivíduos in fectados pelo bacilo poderão desenvolver uma tuberculose grave em pouco tempo ${ }^{36}$. Portanto, radiografar a população com orazos superiores a 6 meses não viria auxiliar de maneira evidente a mudança da situação epidemio lógica atual. Torna-se evidente que o mētodo bacteriológico oferece ajuda concreta aos programas de luta con tra a doença, pode ser empregado a qualquer momento na 
população e deverā sê-lo permanente, propiciando a descoberta constante dos individuos eliminadores de bacilos, que epidemiologicamente são as mais importantes fontes de transmissão da doença.

IV. Reconhecendo-se que a bacteriologia ē a medida diagnōstica prioritāia nos programas de luta contra a tubercu lose, para que o método bacteriológico possa ser coloca do convenientemente à disposição de toda a população do Estado, torna-se necessāria a implantação de uma Rede de Laboratōrios Estadual, que é o objetivo deste traba1ho.

Alguns aspectos, no entanto, devem ser aclarados para que o processo se efetive em nosso Estado:

a) A Rede de Laboratórios de Bacteriologia da Tuberculo se deve ser de àmbito estadual, iniciando-se o processo de implantação por uma área programātica, e ex trapolando-o a todo Estado;

b) Nesta ārea programática a implantacão tem que ser com pleta, isto é, estendida a todos os municípios, cidá des e povoados nas respectivas zonas urbanas e rurais, iniciando-se assim um sistema integrado de co bertura global, respeitadas as vārias etapas da implantação;

c) toda equipe de saūde que participar diretamente do programa na ārea ou āreas programāticas, assim como outros profissionais que atuam no campo da saúde, de verão ser devidamente esclarecidos à respeito da nova metodologia empregada e dos objetivos reais do pro 
grama, propiciando um rendimento efetivo do processo:

d) A população deverá estar preparada para a implantação da nova metodologia e pelo menos ter conhecimentos mínimos de que o diagnóstico da tuberculose tam bém poderā ser feito atravēs do exame de escarro. Es te conceito deverá ficar bem claro à população, parte da qual ainda acredita que apenas o exame radioló gico pode caracterizar a presença ou ausência de um processo tuberculoso.

V. A Rede de Laboratórios de Bacteriologia da Tuberculose poderā se ajustar perfeitamente à atual infraestrutura das Unidades de Saúde do Estado de São Paulo. O potencial formado pela Rede de Laboratōrios de Saúde Pública do Instituto Adolfo Lutz e pelos diversos laboratórios existentes nos vārios centros de Saúde do Estado neces sita apenas de uma coordenacão para que se cumpram os objetivos do programa. Não hă dūvida que, havendo dualidade de atribuições no tocante à realização de exames laboratoriais entre a Coordenadoria de Saúde da Comunidade e a Coordenadoria de Servicos Técnicos Especializa dos, se torna necessário que as atribuicões e responsabilidades de cada setor devam ficar bem especificadas, evitando-se a desintegracão do processo e, consequente mente, do programa.

Deverā ser dada maior atenção às atividades de supervisão, que, pela dualidade de realização de exames, pode rá favorecer o maior número de conflitos. 
VI. o estudo preliminar para a implantação de uma Rede de Laboratōrios de Bacteriologia da Tuberculose realizado na Divisão Regional de Saūde de Ribeirão Preto (DRS-6) mostrou que a implantação de uma Rede de Laboratórios em todo o Estado é perfeitamente possível do ponto de vista econōmico-social e técnico-operacional. Viria, sem dūvida alguma, dar uma cobertura permanente a toda a população, tendo em vista que a ampliação e concretização naquela área do método convencional (baseado na abreugra fia) não preencheriam os objetivos básicos do programa e custariam aos cofres püblicos Cr $\$ 2.279 .200,00$ (dois milhões, duzentos e setenta e nove mil e duzentos cruzeiros), levando-se em conta apenas a compra de material permanente; ao contrārio, para a efetivação da no va metodologia (baseada na bacteriologia), está calcula da em aproximadamente Crs 29.000,00 (vinte e nove mil cruzeiros).

VII. o cālculo do nūmero de baciloscopias que deverā ser rea lizado pelos diversos laboratōrios que comporão a Rede foi estipulado pelo risco anual de infecção 58 , embora a Organizacão Panamericana de Saúde, baseada em trabalhos realizados no México, Peru, Colōmbia e Chile, recomenda que se efetue esse cālculo atravēs dos sintomáticos res piratórios maiores de 15 anos que comparecem para primeira consulta nas entidades gerais de saūde; do percentual de casos positivos provenientes destes sintomáticos, conseguiriamos extrapolar para o resto da popula 
ção e assim calcularmos o número de baciloscopias.

Entretanto, realizamos o cālculo através do risco anual de infeccão, porque nas Unidades Sanitārias não existe uma conduta sistemātica para a descoberta dos sintomāti cos respiratōrios e dos casos positivos que advém dos mesmos. Não há dūvida que, baseando nossos cālculos so mente através do risco anual da infecção (embora o mesmo tivesse sido obtido na prōpria região ${ }^{51}$, , estaríamos correndo o risco de superestimar ou subestimar o número real de casos de tuberculose e, consequentemente, o número total de baciloscopias. Acontece, porēm, que o nū mero de laboratórios que foi estimado para esta região não o foi com base somente no nūmero de baciloscopiasque serā efetuado na região, mas na distāncia entre os muni cīpios, nas facilidades de transporte e nos municípios aonde os doentes por tradicão preferentemente se dirigem. Portanto, o cālculo do número de casos e de baciloscopias através do risco anual da infecção é uma conduta mais de caráter operacional, do que propriamente de ordem tēcnica.

VIII. O nümero diārio de baciloscopias a ser realizado por um laboratório talvez pudesse ser um pouco maior, ao invés de calcularmos aproximadamente 10 baciloscopias diārias para cada laboratōrio. Acontece, porém, que a rotina bacteriológica da tuberculose deverá adaptar-se a uma estrutura de saúde jā implantada e, portanto, o número 
limitado de baciloscopias foi em função de que o micros copista encarregado dos trabalhos poderia realizar, alēm dos exames baciloscōpicos do escarro, uma rotina la boratorial que fosse compativel com os seus conhecimentos como, por exemplo, exames de esclarecimento para a hanseníase e exames parasitológicos de fezes.

IX. O treinamento de pessoal no próprio local do Centro de Saūde deverā dar ao pessoal da Unidade um estīmulo e uma maior motivaça para o desenvolvimento do programa. Acontece, porém, que na DRS-6 pudemos constatar que o nūmero de tēcnicos e auxiliares tēcnicos è muito pequeno, embora a Portaria nọ 8/SSCG, de 05 de junho de 1972 , tivesse previsto para aquela região 27 auxiliares tēcnicos, existindo somente 3 no presente momento. Talvez pudesse se pensar no aproveitamento de atendentes para exercer funções de baciloscopista. No entanto, acreditamos que, sem qualquer estimulo financeiro, seja este através de acesso na escala de referência ou complemen tação atravēs do programa, a Rede de Laboratōrios estarā se deparando com um dos mais sērios problemas, que é o de pessoal. Temos que ter em mente, se vamos dar a qualquer pessoa outras atribuições que se somarão às que ela jā executa, hā necessidade de dar-lhe um estimulo, que em nossa sociedade de consumo se traduz por estimu10 financeiro.

X. A supervisão serā uma atividade importante do programa 
de implantação. Sem supervisão, tudo o que foi planeja do, ensinado e implantado poderā perder o interesse e, consequentemente, a qualidade do trabalho poderā ser con sideravelmente afetada. "0 estudo efetuado na DRS-6 mos trou que a falta de pessoal é um dos problemas para a implantação e efetivação da Rede de Laboratōrios. Para as atividades de supervisão serā necessārio, além de treinar o pessoal que jā trabalha na ārea, talvez contratar novos elementos que ficariam a nível regional $\bar{u}-$ nica e exclusivamente para atividades de supervisão na fase de implantação, pois, levando-se em conta que haverá no mínimo 19 laboratórios a serem supervisionados e estes deverão ser supervisionados diretamente apōs a instalação da Rede, aos $15,30,90,180$ dias, concluise que, se o supervisor conseguisse supervisionar 1 a 2 Laboratōrios Locais por dia, passaria no mínimo 15 dias fora de sua ārea de atividade. Portanto, acreditamos que nessa fase inicial de instalação da Rede um ou dois elementos devem ser contratados ou treinados, com o fim exclusivo de supervisionar, direta e indiretamente, a Rede de Laboratórios Locais. 


\section{CONCLUSDES}

I. A eliminação de doentes baciliferos na população poderā propiciar uma mudança na situação epidemiológica da tuberculose no Estado de São Paulo.

II. Esta eliminação só serā possível atravēs de medidas diagnōsticas permanentes, que atinjam em profundidade a população urbana e rural.

III. A bacteriologia deve ser considerada medida priorita ria nos programas de luta contra a tuberculose em nos so meio, no momento epidemiológico atual.

IV. A criação de uma Rede de Laboratórios de Bacteriologia da Tuberculose, integrada aos servicos gerais de saūde, atenderia permanentemente às reais necessidades da população.

V. Estudo realizado na Divisão Regional de Saūde de Ribeirão Preto (DRS-6) mostrou que a implantação de uma Rede de Laboratórios para atender todos os munici pios que compõem essa Divisão Regional é viável e exequive 1 . 
9. RESUMO

Este trabalho teve por objetivo contribuir para a implantação de uma Rede de Laboratórios de Bacteriologia da Tuberculose no Estado de São Paulo, visando a obter uma modificação efetiva da situação epidemiológica da tuberculose em nosso meio. O autor justifica inicialmente a bacteriologia como medida diagnóstica prioritária nos atuais programas de luta contra a doença. Apresenta, a seguir, um estudo preliminar sobre a implantação de uma Rede de Laboratōrios em uma das Divisões Regionais de Saūde do Estado de São Paulo, mostrando a sua viabilidade e exequibilidade. 
10. SUMMARY

The objective of this paper was to contribute to the implementation of a network of Tuberculosis Bacteriolo gical Laboratories throughout the State of São Paulo (Brazil), designed to change effectively the epidemiological situation of tuberculosis among us. The author justifies bacteriology as the priority diagnostic procedure in the current programmes aiming the control of the disease, and presents a preliminary study regarding the implementation of a network of laboratories in a Regional Health Division of the State of São Paulo, showing its viability and opera tional possibility. 


\section{REFERENCIAS BIBLIOGRAFICAS}

1. AÇAo antituberculose a nível periférico. Brasilia, Di : visào Nacional de Tuberculose/Secretaria de Serviços Médicos do Ministério da Previdéncla e Assistén cia Social, 1974.

2. ALMEIDA, A.P. - Prevalència da infeç̧ão tuberculosa em escolares das capitals brasileiras. Rev.Div. nac. Tuberc., 18:413-44, 1974 .

3. ARANTES, G. R. - Contribulção para a integração das atividades antituberculose nas unidades sanitärias do Estado de São Paulo. Säo Paulo, 1972. (Monogra fla de mestrado - Faculdade de Saúde Pübllca/USP).

4. ARANTES, G. R. - Planejamento antituberculose: valor predictivo do teste tuberculínlco negativo, influência da triagem tuberculínica no valor predictivo da abreugrafia. Säo Paulo, 1974. (Tese de douto ramento - Faculdade de Saúde Püblica/USP).

5. ATKINSON, M. L. - A new method for the evaluation of tuberculosis control programs. HIth. Serv. Rep., $88: 489-92,1973$.

6. BARClay, W. R. - La tuberculosis en los paises desarro lados. IN: SEMINARIO REgIONAL DE TUBERCULOSIS, I?, Maracay y Caracas, 1964. Washington OPS, 1965. p.11-21. (OPAS - Publ. cientifica, 112).

7. BOLETIM EPIDEMIOLOGICO. (Secretaria de Estado da Saúde. Departamento Técnico Normativo. Divisäo Epide miologica) São Paulo, 4 (4), jan./dez. 1974. 
8. BOLETIM EPIDEMIOLOGICO ANUAL. (Secretaria da Saúde. Departamento Técnico Normativo. Divisäo de Eplde miologia) São Paulo, 3 (3), set. 1974 .

9. BRASIL. Divisão Nacional de Tuberculose. Normas para os laboratórios de bacterioscopia da tuberculose. Rió de Janeiro, 1973.

10. BRASIL. Divisão Nacional de Tuberculose. Comissāotéc nica da Campanha Nacional contra a Tuberculose. Açäo antituberculose em nível nacional. Boletim Informativo, Rio de Janeiro (no esp. 2) dez., 1971.

11. BRASIL. Ministërio da Saúde. Gabinete do Ministro. Portaria ne 2, de 20 de janeiro de 1973. Diário ofi cial da União, $05 / \mathrm{fev} . / 1973$.

12. BRASIL. Ministério da Saúde. Gabinete do Minlstro.Por taria ne 2, de 20/jan./1973; retificaçöes. Diärio oficial da Uniäo, $15 / \mathrm{fev} . / 1973$.

13. BRASIL. Serviço Nacional de Tuberculose. Comissāo Téc nica da Campanha Nacional Contra a Tuberculose. Re de de Laboratórios de bacteriologia da tuberculose da Campanha Nacional Contra a Tuberculose. Rev. Serv. nac. Tuberc., 10:373-84, 1966.

14. CAMARA; V. L. - A supervisão em saüde püblica. Rev. Div. nac. Tuberc., 18:165-71, 1974.

15. CERTAIN, D. A. et al. - Analise dos resultados da pes quisa da infeç̧ão tuberculosa e do primeiro programa de vacinação pelo BCG intradérmico em escolares de São Paulo. Rev. Saüde pübl., S.Paulo, 9: 125$136,1975$.

16. CHAN, W. - Bacteriological measures for the detection of cases of pulmonary tuberculosis. Bull.Wld.Hlth. Org., $45: 551-58.1971$. 
17. DIAS FILHO, J. M. - Experiência brasilleira em supervisão direta e indireta em bacteriologia da tuberculo se. (Trabalho apresentado no Curso Regional de Bac teriologia de la Tuberculosis, 8 :, Caracas, Venezue la, 1974. Mimeografado).

18. ECHEVERS, M. J. de O. - La bacteriología en la lucha contra la tuberculosis: métodos técnicos y administrativos aplicables en America Latina. IN: CONGES SO PANAMER ICANO DE TUBERCULOSIS Y ENFERMEDADES DEL APARATO RESPIRATORIO DE LA UNION LATINO-AMERICANA DE SOCIEDADES DE TISIOLOGIA (ULAST), BuENOS AIrEs, 1966. Maracaibo, Venezuela, Comite Regional Latinoamerica no, 1967. p.79-85.

19. EDWARDS, P. Q. - El control de la tuberculosis en paises de baja prevalencia. Bol. Ofic. Sanit. pana mer., $75: 31-43,1973$.

20. EVALUACION de las recomendaciones formuladas por los Grupos de Expertos de la OMS en Tuberculosis. Cron. Org. mund. Salud, 28:487-94, 1974.

21. GOTHI, G. D. et al. - Cases of pulmonary tuberculosis among the out-patients attending general health ins titutions in an indlan city. Bull. Wld. Hlth.org., $43: 35-40,1970$.

22. GRZYBOWSKI, S. Valorização técnlca e operativa de los metodos de localizacion de cases de tuberculosis. in: SEMINARIO REGIONAL DE TUBERCULOSIS, 2 :, BOgOtä, 1972. Washington, DC, OPAS, 1973. P.40-7. (OPAS, Publ. cientiflca, 265).

23. GRZYBOHSKI;'S. E ALLEN, E. A. - The challenge of tuber culosis in decline. Amer.Rev.resp.Dis., 90:707-20, 1964 . 
24. GRZYBOWSKI, S. et al. - Contacts of cases of active pul monary tuberculosis. T.S.R.U. Progress report, 1970. (mimeografado).

25. HERRERA MALMSTEN, L. - Estado actual de la microblologia de la tuberculosis en America Latina. Bol.ofic. sanit.panamer., 68:281-87, 1970 .

26. HERRERA MALMSTEN, L. - Relatörlo da consultoria sobre bacteriologia da tuberculose no Brasil: de 9 de setembro a 19 de outubro de 1974. Washington, D.C., Pan American Health Organization, 1974 . (Brasil$0400)$.

27. HERRERA MALMSTEN. L. - Supervision de la rede de bacte riologia de la tuberculosis. (Trabalho apresentado no Curso Regional de Bacteriologia de la Tuberculosis, 8., Caracas, Venezuela, 1974. (Mimeografado)

28. HITZE, K. L. - La aplicacion de los conoclmientos modernos en la lucha antituberculosa. Cron.org.mund. Salud, $26: 427-33,1972$.

29. HITZE, K. L. - La planificacion de programas nacionales de tuberculosis. IN: SEMINARIO REgIONAL DE TUBERCU LOSIS, 29, Bogota, 1972. Washington, DC, OPAS, 1973. p. 56-73. (OPAS - Publ. cientifica, 265).

30. LARBAQU1, D. - Essai de définition d'une polltlque de déplstage de la tuberculose en Algérie. Rev.Epidem. Med. soc. Santé publ, 19:715-27, 1971.

31. LEHIS, H. W. - Mobile x-ray units: a critical look. Bul1.nat.Tuberc.Ass., $57: 4=5$, oct, 1971 .

32. LOTTE, A., et al. - Données èpidemiologiques et operationnelles et orlentation de la lutte antltuberculeu se en France. Rev. Epidem. Med. soc. Santé publ., 20:683-705, 1972 . 
33. MAGARAO, M.F. - Meios técnicos e administrativos para melhor utilização da microbiologla nos programas de luta contra a tuberculose. Rev. Serv. nac. Tuberc, $11: 5-14,1967$.

34. MARCHAL, G. et al. - La preéminence du dépistage radio logique sur le dépistage bacteriologique est-elle justifièe? Rev. Tuberc. (Paris), 34:648-50, 1970 .

35. MARZZOLLA, E. A. E ARANTES, G. R. - Sugestões para a atualização da rede de unidades sanitärias no âmbito da DRS-6. Ribeirāo Preto, 6a. Divisāo Regional de Saúde da Coordenadoria de Saúde da Comunidade, 1975.

36. MEIJER, J. et al. - Identification of sources of infec tions: Selected Papers, the Hague, 14:5-50, 1971 .

37. MELlo, C.G. de - A interiorização da medicina no Br.asil. Rev. bras. Med., 30:305-11, 1973.

38. MERCENIER, P. - Evaluacion de los programas de lucha antituberculosa. Cron. Org. mund. Salud, 26:604-6, 1972.

39. MEYER, A. E COUDREAU, H. - Remarques sur le dẻpistage de la tuberculose dans de pays en voie de développe ment. Rev. Tuberc. (Paris), 31:401-4, 1967.

40. NAGPAUL, D.R. et al. - Case-finding by microscopy. Bul1. int. Un. Tuberc., 41:148-58, 1968 .

41. NARAIN, R. et al. - Distribution of tuberculosis infec tion and disease among houselrolds in a rural commu nity. Bull. Wld. Hith Org., 34:639-54, 1966.

42. NARAIN, R. et al. - Microscopy positive and microscopy nogative cases of pulmonary tuberculosis. Amer.Rev. resp., Dis., 103:761-73, 1971 . 
43. Oliveira, A.g. de - Plano de expansão dos serviços de tuberculose no Estado de São Paulo. Programa Integrado de Controle da Tuberculose. (Trabalho apresentado ao Congresso Nacional de Tuberculose, 16:, João Pessoa, PB., 1972).

44. ORGANIZAÇAO MUNDIAL DA SAUDE. Comite de Expertos en Tuberculosis, 7\%, Ginebra, 1959. Informe. Ginebra, 1969. Ser. Inf. tecn., 195.

45. ORGANIZAÇAO MUNDIAL DA SAUDE. Commite de Expertos de la OMS en Tuberculosis, 8\%, Ginebra, 1964. Informe. Ginebra, 1964. Ser. Inf. tecn., 290.

46. ORGANIZAÇAO MUNDIAL DA SAUDE. Comite de Expertos de la OMS en Tuberculosis, 99, Ginebra, 1973. Informe. Ginebra, 1974. Ser: Inf. tecn., 552.

47. ORGANIZAÇAO PANAMERICANA DA SADDE - Guia para el diagnöstico de la tuberculosis por el examen microscópi co. Washington, D.C., 1974. (OPAS - Publ. cien tifica, 277).

48. ORGANIZAÇÁO PANAMERICA DA SAUDE - Manual de bacteriolo gia de la tuberculosis: técnicas e procedimientos bä sicos. Washington, D.C., 1973. (CD/TB-ST/LAB).

49. ORGANIZAÇÃO PANAMERICANA DA SAUDE - Normas tëcnicas y administrativas para elaborar e implementar programas de tuberculosis. Washington, D.C., 1975. $(C D / T B / 5)$.

50. RUEDA BERNAL, A. - Programacion de actividades para el control de la tuberculosis. (Trabalho apresentado no Curso Regional de Epidemiologia y Administracion de Programas de Control de la Tuberculosis, 8:, Caracas, 1974 - Mimeografado). 
51. RUFFINO NETTO, A, E ARANTES, G. R. - Risco de Infeç̧āo tuberculosa em município do interior do Estado de São Paulo e suas aplicaçōes. (Apresentado ao Congresso Nacional de Tuberculose e Doenças Respiratórias, 17:, Brasilia, 1975).

52. SANTIAGO, A. da C. - A baciloscopia e a cultura nos programas de luta contra a tuberculose. Rev. Div. nac. Tuberc., 14:283-92, 1970 .

53. SÃo PAULO (Estado). Secretaria da Saúde. Reforma Administrativa: coletânea de textos legais e regula mentares. Säo Paulo, 1971 .

54. SBARBARO, J.A. - Mobile x-ray units: too much effort; to few results. Bull. nat. tuberc. Ass., 57(9):610,1971 .

55. SENTIES V. R., - Programa de localizacion de casos de tuberculosis. IN: SEMINARIO REGIONAL DE TUBERCULO SIS, 2\%, Bogotá, 1972. Washington, D.C., OPAS, 1973. (OPAS - Publ. cientifica, 265).

56. SENTIES, V. R. et al. - El ärea de verificacion dépue bla: un año de experiencia en el programa de control de la tuberculosis. Salud publ., Mex., 13:777 $-786,1971$.

57. STYBLO, K. et al. - Epidemlological and clinical study of tuberculosis in the district of Kolin, Czechoslo vakia: report for the first four years of the stu dy (1961-1964). Bull,WldHith.Org., 37:819-74, 1967 .

58. STYBLO, K. E SUTHERLANDI, 1. - Epidemiological indices for planning, surveillance and evaluation of tuberculosis programmes. Bull. int. Un. Tuberc., 48: $66-73,1973$. 
59. SWALLOW, J. E SBARBARO, J. A. - Analysis- of tuberculo sis case inding in Denver, Colorado, 1965-70. Hlth. Serv. Rep., 87:375-83, 1972 .

60. THORNER, R. M. IF REMIN, D.R. - Principles and procedu res in the evaluation of screening for disease.

Washington, D.C., U.S. Government Printing office, 1961. (Public Health Monograph, 67).

61. UNIAO INTERNACIONAL CONTRA a tUBERCULOSE. Comision La tinoamericana de Bacteriologia de la Tuberculosis, Caracas, 1974. Documento base sobre normas nacionales de bacteriologia de la tuberculosis. Caracas, Venezuela, 1974. (Mimeografado).

62. UNIAO INTERNACIONAL CONTRA A TUBERCULOSE. Comision Ad Hoc pour l'etude de la Classification et de la Terminologie des cas de Tuberculose. Résultats de l'ex périence de lectures multiples de films realisée en 1963. Bull. Un. int. Tuberc., 36:65-78, 1965.

63. VILLAS BOAS, A. - Treinamento de pessoal profissional e auxiliar em um programa nacional de controle de tuberculose. Rev. Div. nac. Tuberc., 18:225-2391974.

64. ZANON, V. E MAGARÃO, M. F. - Recrutamento e formação de pessoal: para um programa de controle da tubercu lose. Rev. nac. Tuberc., 18:158-64, 1974. 
FICHA EXEMPLIFICANDO SISTEMA DE REGISTRO DE EXAMES



FONTE: "Ação antituberculose a nĩvel perifērico" (1). 
-ANEXO II-

FORMULARIO DE PEDIDO DE BACILOSCOPIA E INFORMAÇÁO DE RESULTADO.

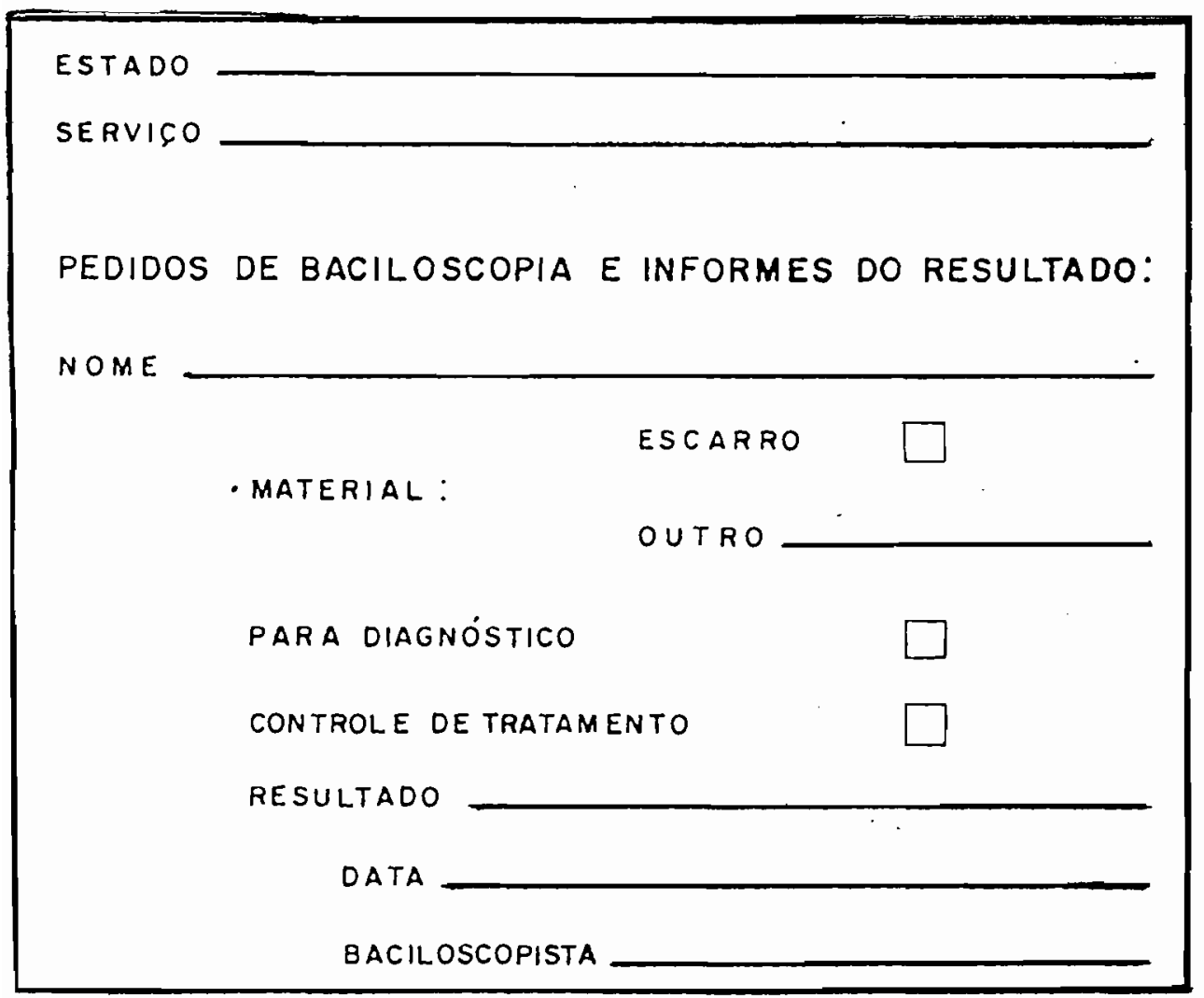

FONTE: "Ação antituberculose a nivel periférico" (1). 
FORMULARIO PARA SUPERVISAO DA TECNICA DE BACILOSCOPIA (f15. 1) FORMULĀRIO PARA SUPERVISÃO

da Técnica de Baciloscopia para Diagnóstico da Tuberculose

Região Data

Serviço Supervisor

1. Entrevista com o Diretor

Problemas existentes:

2. Entrevista com o Chefe de Laboratörio

Problemas existentes:

3. Revisão do Caderno de Supervisão

4. Aspectos de infra-estrutura (coeficiente 2)

Nota 1 a 6 Nota $X$ coef. Total

4.1 Local (ärea de trabalho, iluminação, ordem e asseio, água)

4.2 Pessoal (atitude frente à supervisão, interferência, uso de avental, asseio das mãos)

4.3 Material e equipamento (lâminas, aplicadores, fogareiro, lápis, prateleiras, frascos para reativos, papel negro, papelfiltro, papel de jornal, óleo de imersão, conta-gotas e receptáculo para incineração)

4.4. Organização interna (1ista mural de instruções baciloscópicas, manual de normas de laboratório, caderno de supervisão, limpeza de lâminas, descarte de lâminas positivas, qualidade de lâminas recuperadas e de la minas remetidas para supervisão) 


\begin{tabular}{|c|c|c|c|c|}
\hline & & Nota 1 a 6 & Nota X coef. & Total \\
\hline 4.5 & $\begin{array}{l}\text { Coordenação com outros serviços } \\
\text { (postos de coleta de amostras, } \\
\text { enfermaria e laboratório ime- } \\
\text { diatamente superior) }\end{array}$ & & & \\
\hline 5. & $\frac{\text { Aspectos operacionais }}{\text { (coeficiente 5) }}$ & & & \\
\hline 5.1 & Cumprimento da meta diagnóstico & & & \\
\hline 5.2 & Cumprimento da meta controle & & & \\
\hline 5.3 & Sistema de registro & & & \\
\hline 5.4 & Informação estatística & & & \\
\hline 5.5 & $\begin{array}{l}\text { Rapidez de entrega de } \\
\text { resultados }\end{array}$ & & & \\
\hline 5.6 & $\begin{array}{l}\text { Estado do microscópio (obje- } \\
\text { tiva de imersão, oculares, } \\
\text { platina, aumento usado, defi- } \\
\text { nição ótica) }\end{array}$ & & & \\
\hline 6. & $\frac{\text { Aspectos técnicos }}{\text { (coeficiente 7) }}$ & & & \\
\hline 6.1 & $\begin{array}{l}\text { Amostra (quantidade, quali- } \\
\text { dade, embalagem, identifica- } \\
\text { ção, eliminação da embalagem, } \\
\text { tempo entre coleta e } \\
\text { recebimento) }\end{array}$ & & & \\
\hline 6.2 & $\begin{array}{l}\text { Esfregaço (ponto em que é } \\
\text { colocada a partícula, distri- } \\
\text { buição, homogeneização) }\end{array}$ & & & \\
\hline 6.3 & $\begin{array}{l}\text { Coloração (estado dos reati- } \\
\text { vos, rotulação de frascos, } \\
\text { qualidade da técnica, ava- } \\
\text { liação da lâmina corada) }\end{array}$ & & & \\
\hline 6.4 & $\begin{array}{l}\text { Leitura (técnica, uso de } \\
\text { quadrículas, resultado da } \\
\text { supervisão indireta anterior, } \\
\text { limpeza, objetivo, teste } \\
\text { de eficiência) }\end{array}$ & & & \\
\hline 6.5 & Emprego do método sistematizado & & & \\
\hline
\end{tabular}


FORMULARIO PARA SUPERVISAOO DA TECNICA DE BACILOSCOPIA f1s. 3)

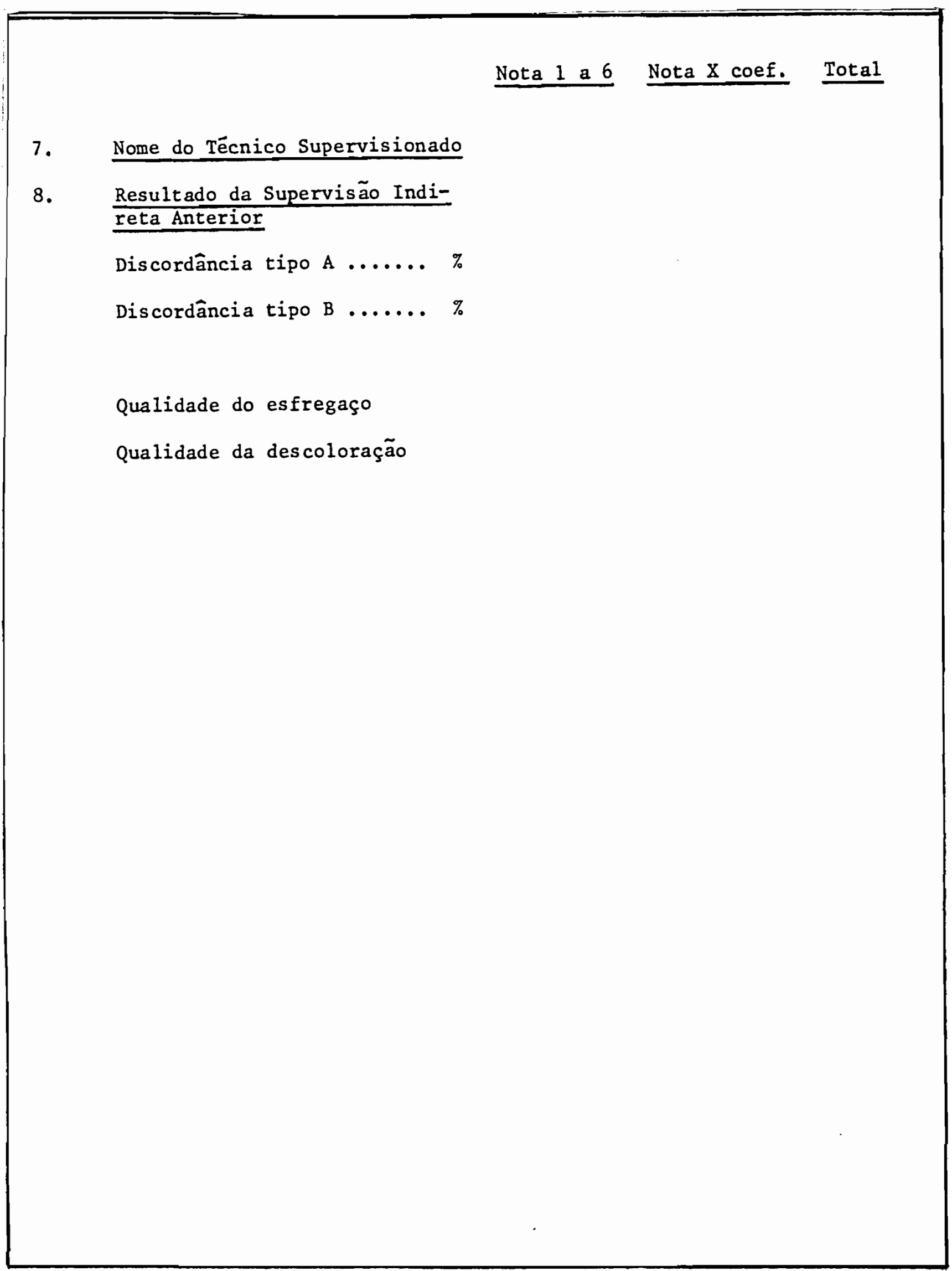

FONTE: HERRERA MALMSTEN, L. (26). 


\section{FORMULARIO PARA SUPERVISÃO DA TECNICA DE BACILOSCOPIA (f1s, 4)}

\section{ASPECTOS DE SUPERVISÃO}

1. Caderno de Supervisão com päginas numeradas

1.1 Na primeira página, devem ser estabelecidas as metas-de-baciloscopia para diagnóstico e as metas de baciloscopia para controle.

1.2 A partir da segunda página, serão anotados, depois-de-cada-visita de controle, os seguintes aspectos:

a) Pontos atribuídos ao laboratório

b) Situação encontrada

c) Providências corretivas tomadas localmente

d) Recomendações deixadas

e) Responsāvel por seu cumprimento

f) Data em que serão cumpridas

g) Assinatura do supervisor e do supervisado, e data

1.3 Na ültima página do caderno será anotado o seguinte sistema de remessa de lâminas:

Eliminar o excesso de óleo das lâminas a serem remetidas, esfregando as levemente com un papel absorvente; mergulhä-las em frasco de xilol; colocá-las na estante para secar. Depois de secas, embrulhālas de tal modo que fiquem separadas umas das outras, e fazer pacotes separados, um para as positivas, outro para as negativas. Em cada lâmina, deve aparecer bem visivelmente o nümero correlativo correspondente.

1.40 laboratorista deverā conservar atē o dia 7 do mês seguinte todas as lâminas positivas de cada dia e $10 \%$ das negativas de cada dia. $\mathrm{Se}$, até o 79 dia, não forem solicitadas pelo laboratório supervisor, procederá à sua limpeza de rotina.

1.5 Cada pacote enviado deverā ter as seguintes indicações:

- Quantidade de lâminas positivas

- Quantidade de lâminas negativas

- Nome do laboratório

- Nome do microscopista

- Data

FONTE: HERRERA MALMSTEN, L. (26). 